\title{
BETWEEN LIFE AND THE UNDERGROUND: \\ A STUDY OF PHOTOGRAPHY FOUND IN ROLLING STONE MAGAZINE
}

FROM 1967 TO 1972.

by

Rachel Lobo, H.B.A, University of Toronto, 2010

A thesis presented to Ryerson University in partial fulfillment of the requirements for the degree of

Masters of Arts in the Program of Film and Photography Preservation and Collections Management

Toronto, Ontario, Canada 2014.

(C) Rachel Lobo 2014 
I hereby declare that I am the sole author of this thesis. This is a true copy of the thesis, including any required final revisions, as accepted by my examiners.

I authorize Ryerson University to lend this thesis to other institutions or individuals for the purpose of scholarly research

I further authorize Ryerson University to reproduce this thesis by photocopying or by other means, in total or in part, at the request of other institutions or individuals for the purpose of scholarly research.

I understand that my thesis may be made electronically available to the public 


\begin{abstract}
In order to consider what the photography used within Rolling Stone magazine contributes to the history of photojournalism, Between Life and the Underground analyzes the aesthetic of the photography and conceptual layouts produced within the magazine. This study looks specifically at the period of 1967 to 1972, a time when mainstream publications like Life magazine ceased production and when over 500 underground publications were piloted. A comparative analysis of the design, economics, and production of both Rolling Stone and the underground publication the Berkeley Barb traces the influence that the underground had on the aesthetic of Rolling Stone's photography and layout. The role that cover photography played in perpetuating the identity that Rolling Stone wanted to embody is also investigated. The influence that New Journalism had on the production of photojournalism at Life and Rolling Stone is also considered-framed around a comparison of the photographic coverage of the Woodstock Festival of 1969 and the police riots at the Democratic National Convention of 1968. This study concludes that the underground press cultivated a new photographic aesthetic and conceptual technique for laying out photographs which adhered to the ideals of the 1960s-namely informality, which Rolling Stone then adapted to create a profitable magazine.
\end{abstract}


"We are star stuff which has taken its destiny into its own hands."

- Carl Sagan, Cosmos

I would like to express gratitude to my supervisor Dr. Thierry Gervais for the useful comments, and engagement through the learning process of this project. I would like to thank you for encouraging my research and pushing me forward. To Mary Panzer, thank you for your recommendations and guidance. Thanks also to David Harris, whose contribution in suggestions and encouragement, helped me to coordinate my project and keep me on track.

In addition, a special thanks to Dr.Gaëlle Morel for helping to coordinate interviews and for her enthusiasm. I would also like to thank Don Snyder and Bob Burley, as they both provided me with many points to include. A special thanks to photographer Baron Wolman for granting me a fantastic interview. To Charlene Heath for a great pep talk and for her sound advice.

I would especially like to thank all my classmates, for their suggestions and laughs - we're all just bricks in the wall. Regina George, she fractured her spine and she still looks like a rock star. To Mum, Dad and (if you have time) Jack for cheering me on. Lastly to Danny, in the vastness of space and immensity of time, it is my joy to share a planet and an epoch, and some snacks with you. 
Table of Contents:

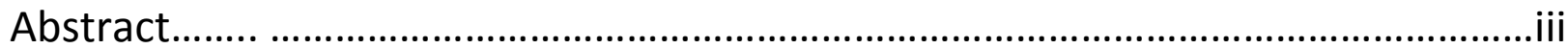

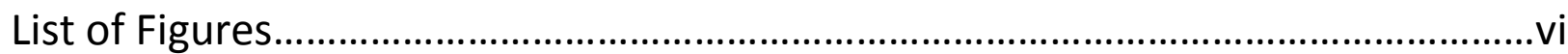

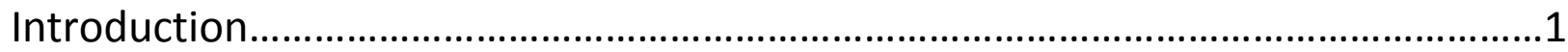

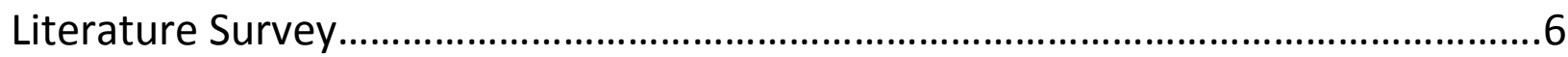

What it Means to Feel It: The Aesthetic of the Underground Press........................16

Rolling Stone's Cover Photography: An Evolution Toward the Mainstream............34

A Comparison of Life and Rolling Stone: A Case Study of Woodstock and the Democratic National Convention of 1968

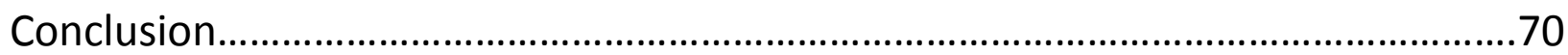

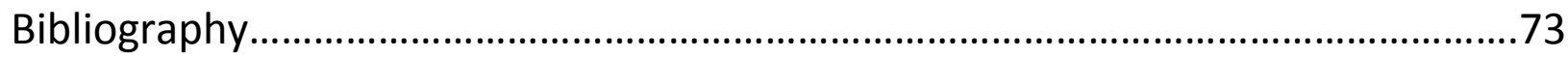

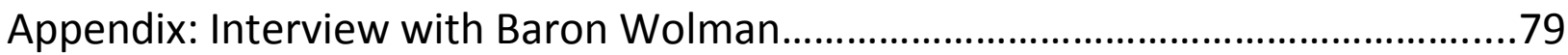


List of Figures

FIGURE 1: Unknown photographer, cover of San Francisco Express Times (March 25, 1969).

FIGURE 2: Alfred Eisenstaedt, Cover of Life (December 28, 1936).

FIGURE 3: Franz Maier, cover of Rolling Stone (May 31, 1969).

FIGURE 4: Ed Ruscha, Standard, Figueroa Street, Los Angeles, 1962, Gelatin silver print.

FIGURE 5: Co Rentmeester, "Special Season of The Young" in Life (July 10, 1970), 46-47.

FIGURE 6: 1968 issue of the Berkeley Barb.

FIGURE 7: Front page of Rags (December 1970).

FIGURE 8: Front page of Gay Sunshine (February to March 1972, no.11).

FIGURE 9: Cover of Rolling Stone (April 6, 1968).

FIGURE 10: Demetre Lagios, "The Lotus \& The Toad" in Rolling Stone (February 21, 1970), 34-35.

FIGURE 11: Premier issue of the Chicago Seed (1967).

FIGURE 12: Unknown photographer, "Hair Rock" in Rolling Stone (December 7, 1968), 20-21.

FIGURE 13: Folded front page of the Berkeley Barb (May 16-22, 1969).

FIGURE 14: Folded front page of "PIGS SHOOT TO KILL-BYSTANDERS GUNNED DOWN" in the Berkeley Barb (May 16-22, 1969).

FIGURE 15: Unknown photographer, "IN COLD BLOOD-JAMES RECTOR: 1944-1969" in the Berkeley Barb (May 16-22, 1969), 3-4.

FIGURE 16: Detail of advertisements in the Berkeley Barb (May 23-26, 1969), 22-23.

FIGURE 17: Detail of advertisements in Rolling Stone (September 16, 1971), 35.

FIGURE 18: Edward Ruscha, Texaco, Jackrabbit, Arizona, from Twentysix Gasoline Stations, 1963. Gelatin silver print.

FIGURE 19: Stephen Goldblatt, "The Beatles" in Rolling Stone (October 26, 1968) 16-17.

FIGURE 20: Unknown photographer, cover of Rolling Stone (November 7, 1967). 
FIGURE 21: Unknown photographer, cover of the Berkeley Barb (July 19, 1969).

FIGURE 22: Gerald Scarfe, cover of TIME (September 22, 1967).

FIGURE 23: Baron Wolman, cover of Rolling Stone (November 23, 1967).

FIGURE 24: Unknown photographer, cover of Rolling Stone (December 14, 1967).

FIGURE 25 Unknown photographer, cover of Life (July 24, 1967).

FIGURE 26: Cover of Life (May 5, 1967).

FIGURE 27: Cover of Look (July 13, 1965).

FIGURE 28: Cover of Ebony (February 1967).

FIGURE 29: Robert Altman, cover of Rolling Stone (October 18, 1969).

FIGURE 30: Album art for Ike \& Tina Turner “DYNAMITE!” (1963).

FIGURE 31: Album art for Dusty Springfield “Where Am I Going” (1967).

FIGURE 32: Unknown photographer "The Rolling Stones" (1964).

FIGURE 33: Gered Mankowitz, "Between the Buttons" (1967).

FIGURE 34: Album art for the Grateful Dead “Workingman's Dead” (1970).

FIGURE 35: Henry Diltz, album art for Crosby, Stills, Nash and Young “Déjà vu" (1970).

FIGURE 36: Annie Leibovitz, cover of Rolling Stone (June 22, 1972).

FIGURE 37: Poster by Mouse Studios for the Grateful Dead (1966).

FIGURE 38: Dean Goodhill, cover of Rolling Stone (August 10, 1968.

FIGURE 39: Front and back covers of Ann Arbor Sun, July 2-8, 1971.

FIGURE 40: Baron Wolman, cover of Rolling Stone (May 17, 1969).

FIGURE 41: Stephen Paley, cover of Rolling Stone issue (October 1, 1970).

FIGURE 42: Unknown photographer, cover of ESSENCE (May 1970). 
FIGURE 43: Unknown photographer, cover of Rolling Stone (June 24, 1971).

FIGURE 44: Annie Leibovitz, cover of Rolling Stone magazine (July 22, 1971).

FIGURE 45: Linda Eastman, cover of Rolling Stone magazine (May 11, 1969).

FIGURE 46: Detail from “Impressions After Woodstock," The Washington Post, August 24, 1969.

FIGURE 47: Detail from “"300,000 at Folk-Rock Fair Camp Out in a Sea of Mud," The New York Times, August 17,1969.

FIGURE 48: Unknown photographer, detail of "The Woodstock Festival" in Rolling Stone magazine (September 20, 1969), 30.

FIGURE 49: Bill Eppridge, “The Big Woodstock Rock Trip" from Life (August 29, 1969), 14-15

FIGURE 50: Bill Eppridge “The Big Woodstock Rock Trip” from Life (August 29, 1969), 16-17.

FIGURE 51: Bill Eppridge “The Big Woodstock Rock Trip” from Life (August 29, 1969), 18-19.

FIGURE 52: Bill Eppridge, "The Big Woodstock Rock Trip” from Life (August 29, 1969), 20-21.

FIGURE 53: Bill Eppridge “The Big Woodstock Rock Trip” from Life (August 29, 1969), 21-22.

FIGURE 54: Baron Wolman, detail of "The Woodstock Festival" in Rolling Stone (September 20, 1969), 18.

FIGURE 55: Baron Wolman, "The Woodstock Festival” in Rolling Stone (September 20, 1969), 26-27.

FIGURE 56: Baron Wolman, "The Woodstock Festival” in Rolling Stone (September 20, 1969), 28-29.

FIGURE 57: Baron Wolman, detail of "The Woodstock Festival" in Rolling Stone (September 20, 1969), 23.

FIGURE 58: Baron Wolman, "The Woodstock Festival” in Rolling Stone (September 20, 1969), 17.

FIGURE 59: “"The Chicago Police Riot” in Life (December 6, 1968), 34-35.

FIGURE 60: "The Chicago Police Riot" in Life (December 6, 1968), 36-37.

FIGURE 61: "Chicago" in Rolling Stone (April 2, 1970), 39-40.

FIGURE 62: "Chicago" in Rolling Stone (April 2, 1970), 43-44.

FIGURE 63: Advertisement in Rolling Stone (February 10, 1968), 22-23.

FIGURE 64: Rolling Stone's “Perception/Reality” Advertising Campaign. 


\section{Introduction}

"Rolling Stone is on the line between so many dichotomies... we're between underground versus aboveground press, between newspaper and magazine, between being a trade paper and a consumer paper, between dope and music."1 -- Jann Wenner

Mirroring the social and political unrest of the late 1960s and early 1970s, the magazine industry was undergoing a transformative period. By 1972, the three largest mainstream American magazines, Life, Look and the Saturday Evening Post all ceased production, leading historians ${ }^{2}$ to categorize this period as the death of the illustrated press. ${ }^{3}$ Like many of its counterparts, though Life experienced record circulation numbers in the late 1960 s, reaching 8.5 million in 1969, substantial losses in ad revenues to television ${ }^{4}$ marked the end of the general interest magazine ${ }^{5}$.

It was during this time of decline in the mainstream press that underground publications began production across America. The 1960s mobilized the anti-racism, women's rights, and student groups around the injustices they experienced under the current system of government. Running parallel to these movements was widespread disapproval regarding America's escalating violence in South Vietnam. In general, there was a revolt against oppressive, artificial, and previously unquestioned ways of living. ${ }^{6}$ What developed was a gulf-between those who rebelled against the conformist culture of the 1950s, and those who felt comfortable. Sometimes referred to as a "generation gap" divided people on issues ranging from hemlines to politics. The generation gap can be attributed to the Baby Boom, which created a large generation of youth with growing market power and influence. The changes occurring in the American magazine industry reflected these societal changes. The tradition of

\footnotetext{
${ }^{1}$ Nicholas Hoffman, “Rolling Stone Gathers Youth," Washington Post, April 23, 1969.

2 John Tebbel and Mary Ellen Zuckerman. The Magazine in America: 1741-1990. New York: Oxford University Press, 1991.

${ }^{3}$ Mary Panzer, Things as They Are: Photojournalism in Context since 1955 (London: World Press Photo, 2005$), 25$.

$4 \quad$ David E. Sumner The Magazine Century: American Magazines Since 1990 (New York: Peter Lang Publishing, 2010), 124.

${ }^{5}$ Benjamin M. Compaine, The Business of Consumer Magazines. (New York: Knowledge Industry Inc, 1982 ), 95.

${ }^{6}$ Howard Zinn, A People's History of the United States (New York: Harper Perennial, 1999), 536.

${ }^{7}$ Gerhard Falk, Youth Culture and the Generation Gap (New York, Algora Publishing, 2005), 1.
} 
underground newspapers, serving a dissident audience, dates back to the American Revolution when Thomas Paine published his pamphlet Common Sense, advocating for basic human rights. In both the $1775 \mathrm{~s}$ and 1960s, the underground press reacted to the revolutionary yearnings of a disenfranchised and radicalized section of the population. The underground press is defined as an independently published magazine or newspaper, providing localized content, which dealt directly with countercultural issues - whether this referred to radical politics, music or sexuality. While fewer mainstream magazines were launched in the 1960s than in any preceding decade, approximately 500 underground publications cropped up all over continental America (with most being published in New York City and San Francisco) between 1964 and 1970. The first notable publication of this kind to have a sustained readership was the Los Angeles Free Press in 1964, followed by twenty new publications in 1967, and culminating in 1969 with at least 300 publications $^{8}$.

The end of the general interest magazine did not signify the end of the illustrated press altogether, but ushered in new methods of representing the news. To illustrate, the front page of the March 25, 1969 issue of the San Francisco Express Times features a black and white photograph from what looks like an outdoor concert [FIG. 1]. Technically speaking the photograph's frame does not encompass each figure entirely, making it difficult to understand the environment where this action is taking place. From a design perspective, the uncoated newsprint, black and white photography and homespun feel of the underground press signified to the reader a distance from corporate media. Berkeley Barb founder Max Scherr describes

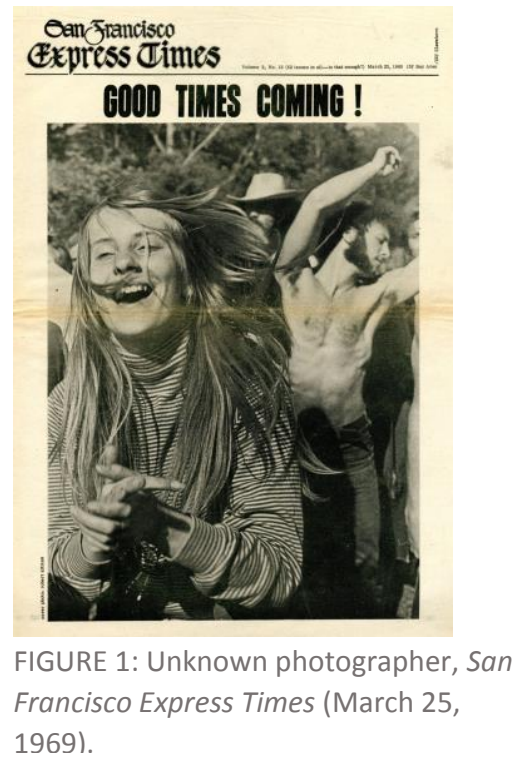

$8 \quad$ John McMillian, Smoking Typewriters: The Sixties Underground Press and the Rise of Alternative Media in America (Oxford: Oxford University Press, 2011), 4. 
this aesthetic: "I am not seeking the understanding of my readers. I want my readers to feel it." ${ }^{9}$ In their championing of "feeling it", the underground press were claiming an aesthetic that was more casual or immediate than that of the mainstream press. However the mainstream press also claimed to offer their readership a feeling of immediacy through images. Both Life and the underground press promoted unpremeditated photographic documentation, however their approaches were aesthetically

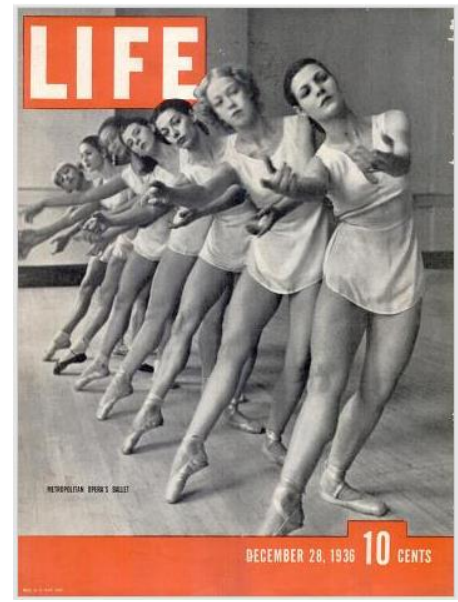

FIGURE 2: Alfred Eisenstaedt, Cover of Life (December 28, 1936).

different. While Life preferred apparently candid photographs ${ }^{10}$ (unposed and undirected) that demonstrated the professional skills of the photographer-vantage point, lighting, and framing - the underground press chose to promote and publish photographs with an amateur aesthetic from the 1960s, capturing spontaneity and action. For example, Alfred Eisenstaedt's photograph of ballet dancers from the Metropolitan Opera's Ballet on the cover of the December 28, 1936 issue of Life is illustrative of this [FIG. 2]. The representation depicts a scene that is highly controlled, at odds completely with the dynamism and casualness of the San Francisco Express Times cover, yet both Life and the underground laid claim to an immediate aesthetic. Similar to the cover of the San Francisco Express Times, in the May 31, 1969 Rolling Stone cover photograph of Jimi Hendrix by Franz Maier, [FIG.3]some figures are cropped out of the frame, and the entire

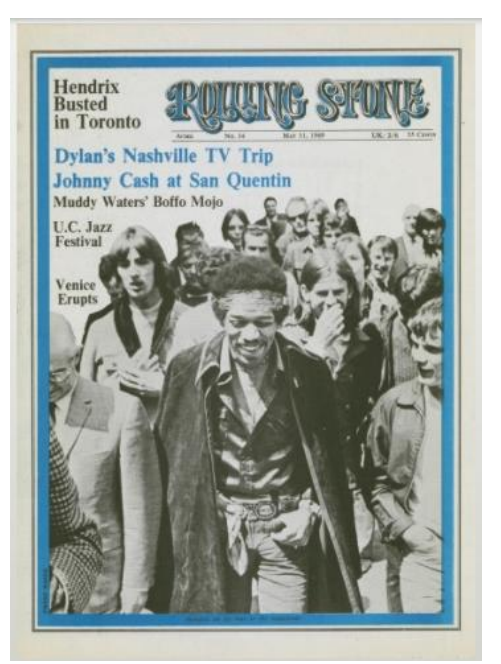

FIGURE 3: Franz Maier, cover of Rolling Stone (May 31, 1969).

\footnotetext{
${ }^{9}$ Robert J. Glessing, The Underground Press in America (Bloomington: Indiana University Press, 1970), 21.

10 This aesthetic is described by historian Wendy Kozol as "realist" in Life's America, where she argues that Life claimed to promote realism using photographic representation that rigidly adhered to Western conventions of perspective and sharp focus, supporting the illusion of a window. However, this notion is questioned by Christopher Vials in Realism for the Masses, and so for the purpose of this study "immediacy" is used to describe the photographic aesthetic.
} 
background has been omitted. In this way the cover is aligned more with the look of the underground that than Eisenstaedt's aesthetically controlled Life cover. Immediacy in print journalism was effectively conveyed through the casual photographic documentation of the underground, which created a successful model that Rolling Stone used in its early years to communicate news with its audience. In a different capacity immediacy was achieved through the long form, subjective genre of New Journalism.

The amateur aesthetic that developed during the 1960's was influenced by family albums, and the low cost photography of the Instamatic ${ }^{11}$, which was reappropriated by artists such as Ed Ruscha to challenge artistic and photographic canons. Ruscha's photographs [FIG. 4] championed immediacy and what was visible - the banal, vulgar landscape of 1960s America. This aesthetic choice was the underground press' way of giving a feeling of proximity to its readership - by taking advantage of a familiar aesthetic, shared

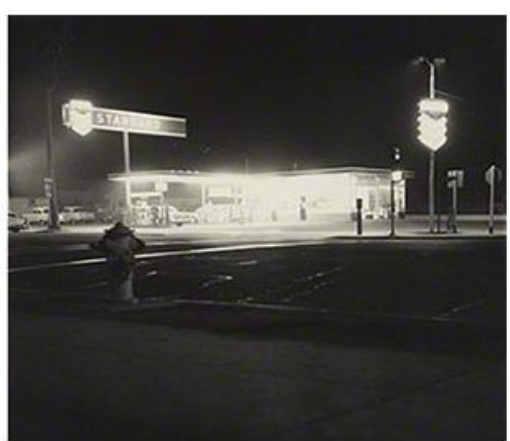

FIGURE 4: Ed Ruscha, Standard, Figueroa Street, Los Angeles, 1962, Gelatin silver print.

by anyone. The style embodied the lack of artifice, a sentiment that reflected the rebellious, youth oriented culture of the 1960 s and its attempts to challenge conformity. This was part of broad effort to challenge mainstream culture on every front-via music, art, fashion, politics, literature etc. This style of unpremeditated documentation was what both the underground publications and Rolling Stone favoured throughout their editorials and on their covers. This casual aesthetic was the style adopted by the underground and Rolling Stone to convey news and seduce their readership.

Life and the underground press will be compared and analyzed in order to better understand how photographs were used differently to convey news at the turn of the 1960 s. The focus of this study is the five year period where the production of each publication overlapped, from 1967 to 1972 . In "What it Means to Feel It: The Aesthetic of the Underground" the ways in which Rolling Stone adopted

\footnotetext{
${ }^{11}$ Geoffrey Batchen, "Snapshots," Photographies, Vol. 1, Iss. 2, (2008), 130.
} 
the informal aesthetic of the underground will be investigated. What becomes clear is that this aesthetic was in part driven by financial limitations, but also was a deliberate aesthetic choice that differentiated the underground from the mainstream. "Rolling Stone's Cover Photography: An Evolution Toward the Mainstream" investigates the influence that the aesthetic of the underground and Life had on the cover photography at Rolling Stone. Though in its early years Rolling Stone was very much aligned with the underground, toward the last years within the scope of this study they were gesturing toward the more aesthetically controlled photographs of the mainstream. Lastly, "A Comparison of Life and Rolling Stone and: A Case Study of Woodstock and the Democratic National Convention of 1968" investigates the influence that trends in journalism had on the photojournalism produced at Life and Rolling Stone. Rolling Stone's layout was impacted greatly by the long-form reporting of New Journalism that emerged in the late 1960s, with photographs playing a more conceptual, secondary role within layouts. Therefore the producers of the underground strategically employed a range of sophisticated visual practices that challenged the conventions of high culture and mass-produced culture ${ }^{12}$. Rolling Stone magazine cherrypicked the most widely accessible aspects of the underground's aesthetic in order to cast its net to a wider market.

${ }^{12}$ Geoff Kaplan, Power to the People (New York: University of Chicago Press, 2013), 80. 


\section{Literature Survey:}

The intention of this literature survey is to analyze the aesthetic and use of photographs in Rolling Stone magazine from 1967 to 1972 for the purpose of situating the magazine within the history of the illustrated press. Texts on Rolling Stone magazine and the underground press were consulted first, followed by histories of photojournalism and general histories of photography, lastly histories of photojournalism that utilize new methods of analysis were consulted. Though press photography manuals, and interviews ${ }^{13}$ were surveyed, as they are primary sources they will not be discussed at length here. Due to the lack of scholarship on aesthetic of Rolling Stone magazine during the late 1960s, this survey also serves as a point of departure for further research.

\section{Histories of Rolling Stone Magazine and the Underground Press}

These sources require a separate subheading, as Rolling Stone and underground press are largely omitted from the histories of photography, photojournalism and journalism. Their inclusion reflects the influence alternative and underground publications had on the aesthetic, editorial and layout choices ${ }^{14}$ used in Rolling Stone magazine in its early years.

Professor of Mass Communication, Dr. David Sumner simply defines New Journalism ${ }^{15}$ as "the use of fiction techniques (scene-by-scene story-telling, character development, dialogue, detailed descriptions etc.) in nonfiction reporting." ${ }^{16}$ Specifically, this trend developed because of a convergence of three historical factors ${ }^{17}$ : “a) the historical events of the 1960 s (the Vietnam war, the civil rights

13 Interviews with Rolling Stone magazine founder Jann Wenner such as, "Like a Rolling Stone" (American Scholar, 1967), "Rolling Stone Gathers Youth" (Washington Post, 1969), and "Questions for... Jann Wenner" (Wall Street Journal, 2006) were reviewed.

$14 \quad$ Texts focused on typology and graphic design were reviewed to further delineate layout and pictorial trends, these include Mixing Messages: Graphic Design in Contemporary Culture (Lupton, 1996) and The Visual Dictionary of Typography (Ambrose, 2011).

${ }^{15}$ This topic will be treated in more detail in Chapter 3, where the influence of proponents of New Journalism like Hunter S. Thompson, and Gay Talese will be discussed.

${ }^{16}$ Sumner, The Magazine Century: American Magazines Since 1900, 140.

17 The historical context of the 1960s and 1970s is provided by Howard Zinn's texts A People's History of the America (Zinn, 1999), and Postwar America: 1945-1971 (Zinn, 1973), Morris Dickstein's Gates of Eden: American 
movement, the women's movement, and hippie-drug counterculture) all of which provided subject matter; b) creative, risk-taking writers and editors; c) the rise of television and its influence on the competitive media marketplace." ${ }^{18}$ Under the subheading, "Jann Wenner and Rolling Stone" the history of Rolling Stone is developed through the biography of founder Jann Wenner, a brief explanation of the counter-cultural movements of Berkeley, California where the magazine was founded, and the writing style of staff writers Hunter S. Thompson and Tom Wolfe. Sumner historicizes Rolling Stone based solely on the writing of a few of its most famous journalists, with no discussion of aesthetic or design practices. However the historical factors listed help to inform the aesthetic choices made at Rolling Stone. In both cases a predetermined narrative is favoured over an account that encompasses both editorial and pictorial trends.

In journalism student Madelaine Cohen's MA dissertation, “Gather No Moss: Vietnam and the Political Evolution of Rolling Stone Magazine"19, the history of Rolling Stone's political writing is traced from 1967 to 2011. A section titled "A Chronology of Politics in Rolling Stone" describes the political climate of Berkeley, California during the post-Vietnam era, the setting in which the magazine was founded, creating a new political space in which to challenge establishment policies and political structure. ${ }^{20}$ Throughout the text, Cohen contextualizes the progressive political ideologies that inform the editorials featured in Rolling Stone, and elucidates on how geo-politics and music converged during the 1960 s and communicated with one another. This sentiment is echoed in a quote from Wenner included in "A Chronology of Politics in Rolling Stone": "The new political movements we feel around us

Culture in the Sixties (Dickstein, 1997), Paul Johnson's A History of the American People (Johnson, 1997) and William H. Chafe's The Unfinished Journey: America Since World War II (Chafe, 2010) which offer lucid and wellcited accounts of the political, social, and economic climate of America during these decades.

18 Sumner, The Magazine Century: American Magazines Since 1990, 148.

19 Madeline Cohen, "Gather No Moss: Vietnam and the Political Evolution of Rolling Stone Magazine," (MA dissertation, Stanford University, 2011).

${ }^{20}$ Ibid. 9. 
can no longer be left at the periphery of the artistic consciousness." ${ }^{21}$ While the dissertation does not speak to the use of photography and layout choices used in the magazine, it provides the necessary context in order to formulate a well-rounded analysis of the founding years of Rolling Stone, when certain stylistic conventions may have been established.

Journalist Robert Draper's Rolling Stone Magazine: An Uncensored History (Draper, 1991) ${ }^{22}$ is the only text that attempts to construct a history of Rolling Stone, providing historical context about the magazine's foundation and the insights into the responsibilities of different members of Rolling Stone's staff. Utilizing testimonials from former staff members, writers, and musicians, Draper constructs a tongue- and- cheek account of the magazine's history from 1967 to 1991 . The first two chapters focus on the personality of Wenner and his incentive for starting the magazine. In the "Prologue" Draper situates Rolling Stone's aesthetic during the turn of the 1960s as a hybrid of underground and mainstream editorial sensibilities; at once embodying the muckracking and lo-fi quality of the underground papers ${ }^{23}$, whilst also prevailing "because of entrepreneurship and dedicated labour force; because debts were overcome and payrolls were met, and because it satisfied a consumer demand" aligned more with mainstream publications. ${ }^{24}$ In the chapter titled "A Goddamned Miracle Every Two Weeks" the only mention of the magazine's layout and aesthetic are discussed through the work of one of the magazine's first art director Robert Kingsbury. Here the design of the magazine is described as clean, with sculptured graphics, heavily influenced by Kingsbury's career as a sculptor. Therefore though this text omits an analysis of the use of photographs it does offer insight into the founding, construction

\footnotetext{
21 lbid., 13.

${ }^{22}$ Robert Draper, Rolling Stone Magazine: An Uncensored History, (New York: Harper Perennial, 1991).

$23 \quad$ When discussing the so-called "lo-fi" quality, Draper is referring to the period between 1967 and 1972 when Rolling Stone used a duotone folded tabloid newspaper format. Though Art Director Robert Kingsbury helped to de-clutter the layout, compared to the mainstream publications of the time, the quality of Rolling Stone magazine was still considered to be lo-fi.

${ }^{24}$ Draper, Rolling Stone Magazine: An Uncensored History, 7.
} 
and institutional organization of the magazine. However its lack of citation forces the reader to rely on the word of the author.

Throughout A Bomb in Every Issue: How the Short, Unruly Life of Ramparts Magazine Changed America $^{25}$ author Peter Richardson constructs a history of the San Francisco based muckracker Ramparts and its tradition of progressive journalism. Within this history, Richardson charges Rolling Stone magazine founders Wenner and Ralph Gleason with co-opting the successful visual syntax and journalistic style of Ramparts and marketing it to a more mainstream audience. Because Ramparts and Rolling Stone are so closely linked in terms of staff and geography, ${ }^{26}$ the historical context provided by Richardson is applicable to an analysis of Rolling Stone. Of particular value is the description of offset printing during the late 1960s: "Technology and finance were also changing the media landscape. Berkeley journalism professor Lowell Bergman, who started his career as a typesetter, noted that the falling costs of offset printing combined with generous credit from printers helped new magazines and newspapers find their audiences."27 Much like the histories of mainstream photojournalism and journalism which will be reviewed here later, Richardson's text omits a visual analysis of Ramparts and Rolling Stone in favour of an investigation of the editorial content, which is formulated by a survey of the magazine's most famous contributors.

In the chapter titled “'Either We Have Freedom of the Press... or We Don't Have Freedom of the Press'" in media historian John McMillian's Smoking Typewriters: The Sixties Underground Press and the Rise of Alternative Media in America ${ }^{28}$, Rolling Stone is analyzed from a marketing standpoint as:

“[Wenner's] magazine was generally favourable toward cultural and the commodifiable aspects of the

25 Peter Richardson, A Bomb in Every Issue: How the Short, Unruly Life of Ramparts Magazine Changed America, (New York: New Press, 2009).

${ }^{26}$ Both Wenner and Gleason worked for Ramparts prior to founding Rolling Stone.

${ }^{27}$ Richardson, A Bomb in Every Issue: How the Short, Unruly Life of Ramparts Magazine Changed America, 175. $28 \quad J o h n$ McMillian, Smoking Typewriters: The Sixties Underground Press and the Rise of Alternative Media in America (Oxford: Oxford University Press, 2011). 
youth rebellion, while thumbing its nose at New Left political activism. As a result, the magazine was able to lure advertisers and readers that were apprehensive to the [countercultural] movement's growing militancy." ${ }^{29}$ Furthermore, in his chapter "Culture and Community in the 1960s Underground Press", McMillian describes communities like Berkeley, California as supplying a politically and culturally in-tune audience that allowed smaller publications to grow and flourish. Similar to Richardson's text, McMillian does not address the history of Rolling Stone head on, but even through its peripheral treatment, the historical context and analysis of the more technical and bureaucratic aspects of the underground press apply to the foundation of Rolling Stone.

The recent publication dates of the latter texts (Richardson in 2009 and McMillian in 2011) reflects a burgeoning interest in these publications. However, the focus of these texts gives preference to analysis of publication and social trends over any discussion of the visual culture of the magazine, including photography, layout, and design by use of examples.

\section{General Histories of Photojournalism and Photography}

Consistent with the more focused studies on the history of photojournalism, Rolling Stone is omitted from the larger volumed histories of photography as well. The main function of histories of photography in this research is to provide the necessary historical context for photographic trends during the late 1960 s and early 1970 s, in order to understand the aesthetic choices-primarily the looseness of the aesthetic-made at Rolling Stone during this period.

In the chapter titled "The Straight Image" in the Fourth Edition of $A$ World History of

Photography $y^{30}$ Naomi Rosenblum describes the aesthetic of the social landscape approach as appealing "especially to photographs whose reality tended to be disjunctive and who no longer canonized

${ }^{29}$ Ibid. 122.

${ }^{30}$ Naomi Rosenblum, A World History of Photograph (New York: Abbeville Press, 2007). 
previsualized, the beautifully printed, large-format camera image. ${ }^{\prime 31}$ Rosenblum traces the lineage of this aesthetic choice by linking it to the appetite for naïve camera imagery accorded by the era's taste for vernacular and pop culture. The subject of social landscape photography was then the artifacts of the era, like soup cans and road signs, captured without any sentimentality. From here Rosenblum describes the influence of the social landscape photography left, namely in inspiring in its levity the humourous photography of Elliot Erwitt and Burk Uzzle. However the larger historical context for this kind of image making is left out of Rosenblum's account, making it difficult to understand the cultural relevancy of the amateur aesthetic.

Though Tim Gidal's analysis in Modern Photojournalism: Origin and Evolution, 1910-1933 ${ }^{32}$ falls outside of the scope of this study, his text discusses the idea of a natural aesthetic in press photography. In "IV. The Development of Modern Photoreportage" Gidal describes photojournalist Erich Salomon's pictures: "his pictures completely changed the character of indoor reports... completely unposed and undirected interior photographs of... unselfconscious subjects began to appear in magazines." ${ }^{33}$ Gidal goes on to categorize this aesthetic as the aesthetic of the new photojournalism of the $1930 \mathrm{~s}$, establishing an historical precedent to the style of photography seen in Rolling Stone. The main difference then between the photojournalism of the 1930s and the photojournalism featured in Rolling Stone is the conceptual layout of the photographs and the legibility of the photograph-its tonal fidelity and sharpness. Also, unlike in the late 1960s where this aesthetic was driven by the cultural tastes of the time, Gidal describes unposed photography as something tied to the individual photographer's instinct, planned on a psychological basis. Here Gidal attributes the aesthetic of photojournalism solely to the photographer with no intervention by editors or art directors. This attribution could perhaps be a symptom of Gidal's own career as a photojournalist.

\footnotetext{
31 Ibid. 526.

32 Tim Gidal, Modern Photojournalism: Origin and Evolution, 1910-1933, (New York: Macmillan Publishing Co.,Inc., 1973).

33 lbid., 17.
} 
In journalist Harold Evans' Pictures on a Page: Photo-journalism, Graphics and Picture Editing ${ }^{34}$ the effects of editing and design are considered in terms of their function on the printed page. In his chapter titled "The Third Effect", the role that juxtapositions and coupling play in the design of a news story are outlined. Here he describes the importance of having little negative space on a page, for Evans "photojournalism is assisted by the bold simplicities and sense of value of space..." ${ }^{35}$ This passage effectively highlights the breaking with tradition seen in magazines like Rolling Stone, where conceptual layouts are published with little mind of how much negative space is produced in the process. Overall, through its careful unpacking of the "rules" of photojournalism and rich examples from published news stories, Evans' text showcases the many representational conventions of classic photojournalism. What is problematic is the author's focus on newspapers (namely The Sunday Times), the rigid guidelines that he presents, and that he gives primacy to a photograph's visual content over the mood or atmosphere that it conveys.

What is omitted from Rosenblum's account is an analysis of the wider applications of the aesthetics of the 1960s. In both Rosenblum's and Gidal's text the discussion is situated under the umbrella of a famed photographer's oeuvre whether this be Robert Frank, Diane Arbus or Lee Friedlander. The wider dissemination of this kind of photography needs to be addressed, specifically how this aesthetic permeated into print journalism, where it was more publically accessible. In a similar way Gidal's text is limited in its analysis of what drove the taste for unposed photographs during the 1930s. Gidal's also frames his discussion of the aesthetic of the press photographs of the 1930s within a discussion of Erich Salomon. Conversely, Evans makes little reference to the photographers that produced the photographs that provide his text with so many examples. Unlike Rosenblum and Gidal, his text does not present a history of how editing techniques or aesthetics evolved over history, so his

\footnotetext{
${ }^{34}$ Harold Evans, Pictures on a Page: Photo-journalism, Graphics and Picture Editing, (London: Heinemann, 1978). 35 Ibid, 248.
} 
book reads more like a manual then a historical narrative. Similar to the histories previously reviewed, a focused study on the illustrated press and the cultural and historical influences of the 1960s that shaped its photographic content has yet to be conducted.

\section{$\underline{\text { Histories of Photojournalism and Journalism }}$}

The next two texts included in this survey were chosen because they provide reproductions of layouts from magazines and newspapers. They construct their histories of photojournalism using only the material which was printed in magazines, as they originally appeared allowing for a broader understanding of how photographs are disseminated to the public. What Mary Panzer's Things as they $a^{36} e^{36}$ and Robert Lebeck and Bodo von Dewitz's Kiosk: A History of Photojournalism ${ }^{37}$ offer deviates completely from the way photojournalism is historicized. Histories offered in texts such as Gidal's Modern Photojournalism: Origin and Evolution 1910-1933 from 1972, illustrate their narratives on photojournalism using images divorced from the conditions of their original publication. In Gidal's history layouts are neatly cropped, inhibiting the reader from understanding these images as threedimensional objects.

\section{Photojournalist and collector Lebeck and curator Von Dewitz's Kiosk: A History of}

Photojournalism uses reproductions of news reports accompanied by chronological essays in order to build a history of photojournalism in illustrated news magazines from 1839 to 1973. Rolling Stone magazine is overlooked in this history, however the chapter titled "1960-1973: Classical Reports", though not extensive or unique in its textual analysis of the illustrated press during the 1960s and 1970s, reproduces layouts which help to reveal the types of editorial practices used during this time period. In the text that accompanies this chapter, Lebeck describes photojournalism as being in decline in the early

\footnotetext{
${ }^{36}$ Mary Panzer, Things as they are: Photojournalism in Context since 1955, (London: World Press Photo, 2005). 37 Robert Lebeck and Bobo Von Dewitz. Kiosk: Eine Geschichte der Fotoreportage 1839-1973/ A History of Photojournalism, (Göttingen: Steidl, 2001).
} 
$1970 s^{38}$ in America, giving saliency to the endpoint (1973) of his analyses of photojournalism, but omitting magazines like Rolling Stone, that were newly founded during this time. A reading of these chapters illustrates the importance of layout in understanding of the uses of photography as well as the role that the picture editor has on the aesthetic of the page.

In her "Introduction" to Things as they are, historian Mary Panzer surveys the history of photojournalism from 1842 to $2005^{39}$, constructing this history with a focus on magazines. Referring to the post-Life magazine era of photojournalism under the subheading "The Last Decades", Panzer contests the notion that photojournalism died when Life magazine folded in 1972 . For her, the tradition of incisive journalism lived on in magazines serving a more specialized audience, such as Rolling Stone. This reference remarks on the editorial content of the magazine, specifically the work of journalists Hunter S. Thompson and Tom Wolfe, and does not address the pictorial content of the magazine. This is the only mention of Rolling Stone incorporated into Panzer's history besides the inclusion of a picture essay by Richard Avedon titled "The Family" originally published in Rolling Stone in 1976 (which falls outside the scope of this study). As in Kiosk no comprehensive analysis of Rolling Stone is provided, however in the chapter "1965-1974: The Vietnam Era" the inclusion of picture essays reproduced in their original layout ${ }^{40}$ helps to articulate representative conventions that predominated and evolved in the illustrated press during the late 1960s and early 1970s. Things As They Are and Kiosk represent a recent shift toward three-dimensionality, an effective method of contextualizing press photographs Though none of these sources provide a comprehensive analysis of the aesthetic used in the photography at Rolling Stone, by offering a broad history of photojournalism, these texts offer a

\footnotetext{
${ }^{38}$ For Lebeck and von Dewitz, the end of Life and Look signal this decline.

39 Though the body of the book traces the history of photojournalism from 1955 to 2005, in her Introduction Panzer's history begins in 1842 and hypothesizes trends in photojournalism beyond 2005.

$40 \quad$ The press photography manuals, The Technique of the Picture Story: A Practical Guide to the Production of Visual Articles (Mich and Eberman, 1945), Words and Pictures: An Introduction to Photojournalism (Hicks, 1952), Pictorial Journalism (Vitray and Mills, 1973), Picture Editing and Layout: A Guide to Better Visual Communication (McDougall, 1990), will be used to delineate any editorial tropes and representative conventions.
} 
foundation with which object-based and archival research can help further develop. What Kiosk and Things as they are suggest in their recent publication date is that interest in further developing histories of photojournalism based on original publication context is perhaps developing-opening the door for more technical analyses of magazines such as Rolling Stone to be undertaken. 


\section{What It Means to 'Feel It': The Aesthetic of the Underground Press}

In an interview with a Time reporter a combative Bob Dylan asserts, "You don't know the people who read the magazine... How can you, sitting in an office in New York? Do you really care about what you say? I know more about what you do than you'll ever know about me. ${ }^{41 "}$ Dylan's tirade aptly summarizes the spirit of the underground press: creating content and providing agency for those who were disillusioned by the current political system and sought an alternative. The alternative that the underground press provided was two pronged: it offered frank, radical, political commentary, and an aesthetic all to its own-low tech,

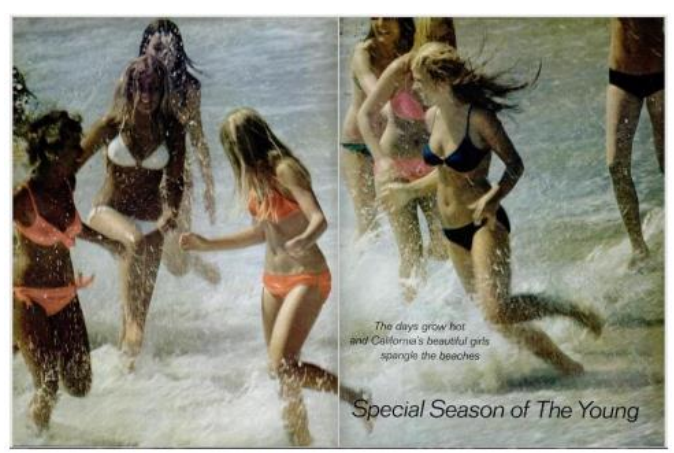

FIGURE 5: Co Rentmeester, "Special Season of The Young" in Life (July 10, 1970), 46-47.

disorganized, and conceptual. Unlike the large, splashy

photographs beautifully laid out throughout the pages of Life [FIG. 5], the Berkeley Barb, one of the most successful underground publications, was often referred to as "the world's ugliest newspaper."

[FIG. 6] $]^{42}$ At odds with the claim to present an unmediated version of reality through a photograph's indexical status, the underground press favoured imagery that refused straightforward documentation. ${ }^{43}$

The Berkeley Barb was produced in four-fold tabloid style on newsprint and measured $44 \mathrm{~cm}$ by $55 \mathrm{~cm}$ when opened.

The use of haphazardly framed photographs, the garish use of black ink and slapdash layouts represented exactly what the Berkeley subculture wanted: a visual alternative to the
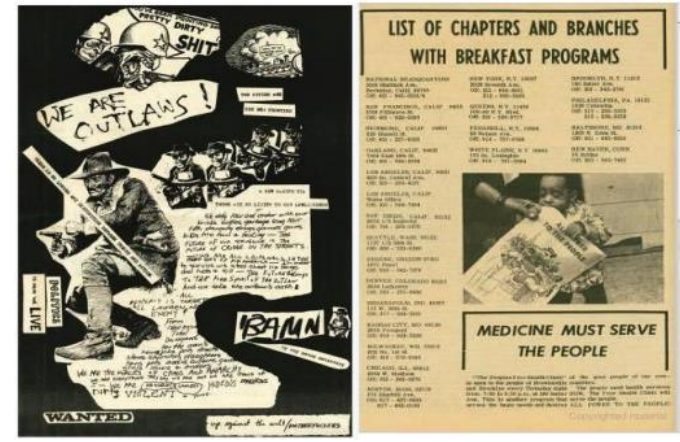

FIGURE 6: 1968 issue of the Berkeley Barb. mainstream.

\footnotetext{
${ }^{41}$ Gennari, "Bridging Two Americas: LIFE Looks at the 1960s," 267.

${ }^{42}$ Robert J. Glessing, The Underground Press in America (Bloomington: Indiana University Press, 1970), 20.

${ }^{43}$ Kaplan, Power to the People, 100.
} 
What allowed for the widespread production and consumption of underground publications in the 1960 s can be attributed to three factors: the widespread introduction of offset printing, an untapped audience of dissidents, and a labour pool of activists. ${ }^{44}$.Though Rolling Stone strove for more professionalism than the underground press, it was these same three factors that also allowed Rolling Stone to flourish in the late 1960s. Early on Jann Wenner expressed a desire to distance himself from the underground publications, "When we started out we really had the idea that we were gonna [sic] be different from the underground papers... their reporting was sloppy, their layout was ugly and they espoused radical sandbox politics... we didn't want to look like them, or be like them." ${ }^{45}$ In many cases Rolling Stone was coopting the more palatable aspects of the underground press, but abandoning its revolutionary temperament in order to market content to a wider audience. The success of Berkeley Barb, selling an average of 85,000 copies in 1969 showcased to Rolling Stone that there was a market for this lo-tech aesthetic.

It is important to note that the formation of an underground press is categorically a response to the historical conditions of its production. As such, the representational strategies of the underground were dictated greatly by the historical moment. Just as in 1831 when Frederick Douglas and William Lloyd Garrison used Liberator to lobby for the abolition of slavery, and in 1907 Emma Goldman's anarchist journal Mother Earth opposed World War One and advocated for the labour movement, the underground press in the 1960 s rejected an imperial foreign policy and a conformist way of life. ${ }^{46}$ Therefore in order to understand the impetus for the creation of the underground press, its aesthetic choices, and its influence as seen in Rolling Stone, it is essential to understand the history of the 1960s in America. This history informed the content, structure and development of this small-scale, grassroots form of an illustrated press. Beginning in the 1960s the power structures that exerted the most

\footnotetext{
${ }^{44}$ Stewart, On the Ground: An Illustrated Anecdotal History of the Sixties Underground Press in the U.S.,1. $45 \quad$ McMillian, Smoking Typewriters: The Sixties Underground Press and the Rise of Alternative Media in America, 229.

${ }^{46}$ Peck, Uncovering the Sixties: The Life and Times of the Underground, xiv.
} 
repressive force on the American population experienced a forceful pushback. As Noam Chomsky explains, it was during this time when, "large groups of people who are normally passive and apathetic began to try to enter the political arena to press their demands." ${ }^{47}$ Citizens that were normally indifferent to American domestic and foreign policy began responding to the struggles against racism, against war, against poverty, and against police brutality. The myth of the American Dream and American exceptionalism was beginning to form cracks - an event that had a seismic effect on the general interest magazine. In his Postwar America: 1945-1970 historian Howard Zinn unpacks the truth about the state of America during this period:

"The [Second World War] revealed the American system of liberal capitalism at its best: enormously efficient in technology, abundant in jobs and money, united in struggle against a repressive enemy [Axis forces], pulsating with noble declarations and marvelous intentions for the world... At its best America's generosity toward its allies masked nationalist expansion... Not until the sixties did this confidence begin to break down, as crisis after crisis-in race relations, in the distribution of resources, in foreign policy-indicated that something was terribly wrong ${ }^{48} . "$

Here Zinn alludes to the disproportionate allocation of Post World War II America's resources and the effect this had on the larger population. As historian William H. Chafe discusses in The Unfinished Journey, though this time period if often historicized as a time of affluence, the distribution of wealth remained firmly in the hands of the upper fifth of society, who lived on twenty to thirty thousand dollars a year ${ }^{49}$, compared to the bottom fifth who survived on two to three thousand dollars a year ${ }^{50}$. Government spending did nothing to ease the burden of those in poverty, with resources allocated to

\footnotetext{
${ }^{47}$ Noam Chomsky, Manufacturing Consent, lecture at the University of Wisconsin (15 March 1989).

${ }^{48}$ Howard Zinn, Postwar America: $1945-1971$ (Indianapolis: Bobbs-Merrill: 1973), xii.

49 William H. Chafe, The Unfinished Journey: America Since World War II (New York: Oxford University Press, 1986), 143.

50 Zinn, Postwar America: 1945-1971, 89.
} 
war goods ${ }^{51}$ and luxury goods instead of health care, education and housing. The construction of highways, motels and restaurants further demonstrated that where resources were spent on infrastructure these amenities only served the upper and middle class. The infrastructure and the rise of consumer culture became so emblematic of 1960s America that it developed into an important subject for artists like Ruscha and Warhol. The low quality aesthetic of the underground was therefore important to distancing themselves from the mainstream, corporate press. Even amongst the middle class, who are often the highlighted in traditional histories of America as epitomizing the bountiful postwar years, there was growing dissatisfaction with work, crowdedness on the highways and cities, nagging fears about depression, The Bomb and security. ${ }^{52}$ For one these issues ushered in the questioning of the social norms of the 1950s, and the possibility of an alternative. More radically, groups of the population began to rally against the systemic issues that plagued American society, namely racism, women's rights, and the imperialist war in Vietnam. The hallmark of both foreign and domestic policy was the extremely narrow range of permissible debate, and so young people in the late 1960s were looking for something in literature, art, and news that was relevant. ${ }^{53}$ This provided ample content for the underground press, which used their pages as a means to confront these issues. The underlying current in all of these movements was the need for a critical examination of American society and a fundamental shift in the political structure. For the authors of the underground press, whether writers, editors, or photographers, these issues necessitated different representational strategies than what mainstream publications offered. This manifested itself mainly in new forms of layout, photographic documentation and journalism.

This process of democratization permeated many levels of society, affecting the most personal

51 Christopher Chantrill, "Total Spending for the US- Fiscal Year 1962," US Government Spending, http://www.usgovernmentspending.com/piechart_1962_US_total (accessed August 31, 2014). 52 Ibid.

$53 \quad$ Morris Dickstein, Gates if Eden: American Culture in the Sixties (New York: Basic Books, Inc., Publishers, 1977), 13-26. 
aspects of people's lives. Sometimes historicized as a "generation gap" 54 or the "counterculture", there was an attempt by many Americans to pierce the many layers of artifice piled up by civilization and rediscover the root needs of human beings. ${ }^{55}$ This manifested as a loosening of traditions when it came to sexual exploration, living situations, dress, religion, music, literature, education etc. Perhaps most visibly disaffected with established ideals were the youth of the time. The post war baby boom meant that there was an unprecedented amount of young people coming of age in the late 1960s. For this demographic, their adolescence was occurring at a time of defiance and exploration. Their rebellion elicited a cultural response, for many folk-rock and rock n' roll music echoed their beliefs most loudly. An anthem for the time, in Bob Dylans' 1964 "The Times They Are a-Changin'” he expounds, "Come mothers and fathers throughout the land, and don't criticize what you can't understand. Your sons and your daughters are beyond your command, your old road is rapidly agin'. Please get out of the new one if you can't lend your hand, for the times they are a-changin'.."56 For youth and older people alike the political, social and cultural changes of the era widened the myopic scope of possibilities established in previous decades. Proponents of countercultural and political movements of the time were the producers and consumers of the underground press, making the underground press a vast and amorphous scene. ${ }^{57}$ One that made the decision to distance themselves from mainstream publications by delivering the news to people in a different way, both editorially and pictorially.

\footnotetext{
${ }^{54}$ Falk, Youth Culture and the Generation Gap (New York, Algora Publishing, 2005), 1.

${ }^{55}$ Zinn, A People's History of the United States, 232.

56 Bob Dylan, "The Times They a-Changin"” (song lyrics), accessed April 30, 2014, http://www.metrolyrics.com/the-times-they-are-achangin-lyrics-bob-dylan.html

57 Sean Stewart, On the Ground: An Illustrated Anecdotal History of the Sixties Underground Press in the U.S. (Oakland: PM Press, 2011),1.
} 


\section{Appropriating the Underground}

From its premier issue, the members of the underground treated Rolling Stone with a sense of suspicion-mainly for its "upscale underground appearance" 58 and the reformist attitude of its editorials. A key historical function of the underground press is advocating for social and political change, and so Rolling Stone's focus on music separates them from this tradition. Though for musicians like Dylan, music and social change went together, Rolling Stone often focused more heavily on the music and not the message behind it. When it appeared on newsstands Rolling Stone's duotone, fourfold tabloid format, uncoated stock, serrated edges, and psychedelic design seemed to signal to its readers its allegiance to the counterculture by virtue of its aesthetic differences with the mainstream press. These similarities are easily distinguished in a comparison of the covers of the Rags [FIG.7],Gay
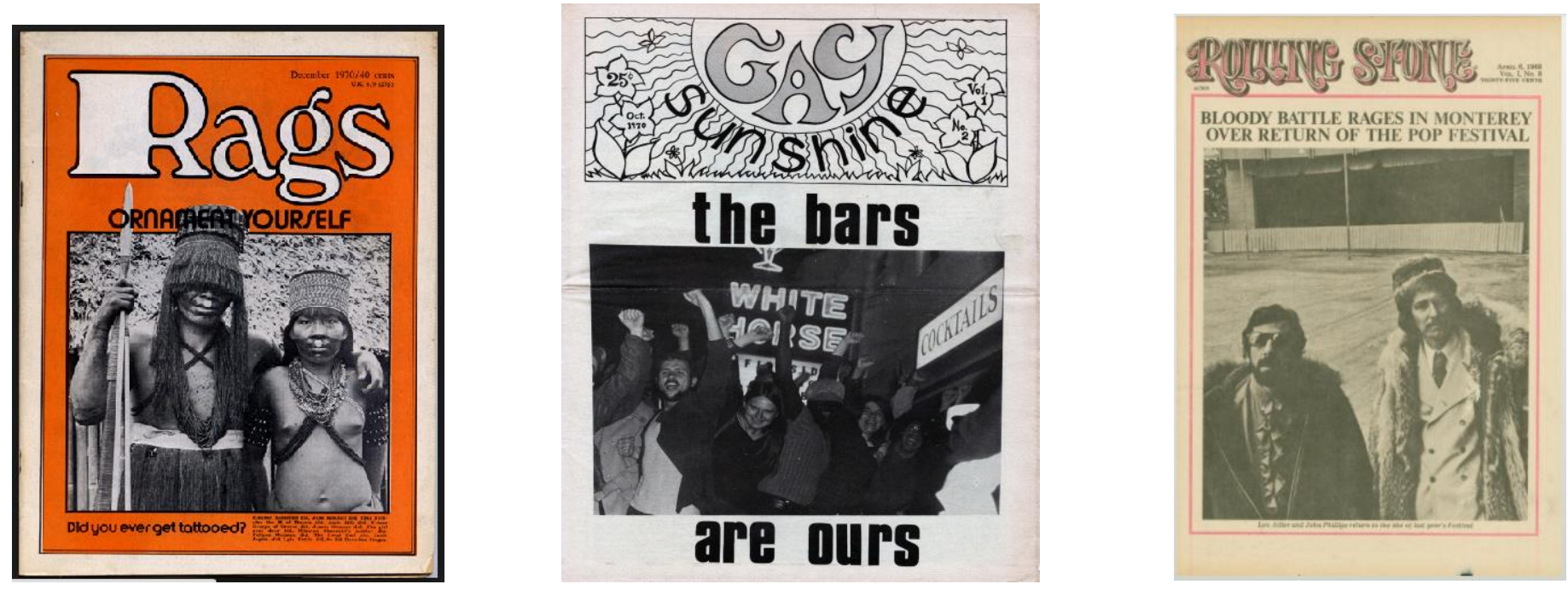

FIGURE 7 (left): Front page of Rags (December 1970).

FIGURE 8 (centre): Front page of Gay Sunshine (February to March 1972, no.11).

FIGURE 9 (right): Cover of Rolling Stone (April 6, 1968).

Sunshine [FIG.8], and Rolling Stone [FIG.9]. In each publication scotch rules or negative space encloses the masthead and photograph, with the duotone format dictating that one dominant colour be

$58 \quad$ McMillian, Smoking Typewriters: The Sixties Underground Press and the Rise of Alternative Media in America, 122. 
presented and the photography be in black and white. Beyond the cover, conceptual layouts accentuate the curvature of the photographs, rather than cutting the photographs into rectolinear shapes like in traditional magazines. In the February 21, 1970 issue of Rolling Stone the article "The Lotus \& The Toad" presents Demetre Lagios' photographs of players of The Floating Lotus Magic Opera silhouetted to creative interesting shapes [FIG. 10]. The mainstream favoured rectolinear shapes, little negative space, and larger photographs with hardly any room for text. Visual choices like this were much

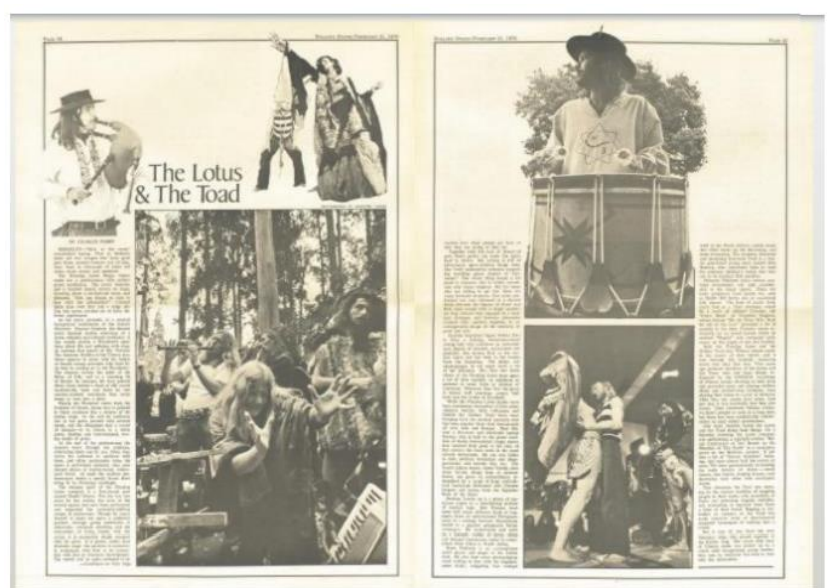

FIGURE 10: Demetre Lagios, "The Lotus \& The Toad" in Rolling Stone (February 21, 1970), 34-35.

more aligned with the underground. Take for instance, the premier issue of the Chicago Seed from 1967, where a black and white portrait of a nude woman is cut to form a teardrop shape [FIG.11]. There was a clear choice by the producers of Rolling Stone to tap into the zeitgeist of the 1960s. As illustrated by the earlier Dylan quotes, rock music carried the banner for the revolutionary sentiments of the underground press and so it is no wonder that the music publication Rolling Stone sought to align itself with these sentiments through similar design choices. Former Art Director for the New York Times Steven Heller describes this kind of appropriation in his article "Underground Mainstream": "Psychedelic art was a distinct vocabulary, influenced by earlier graphic

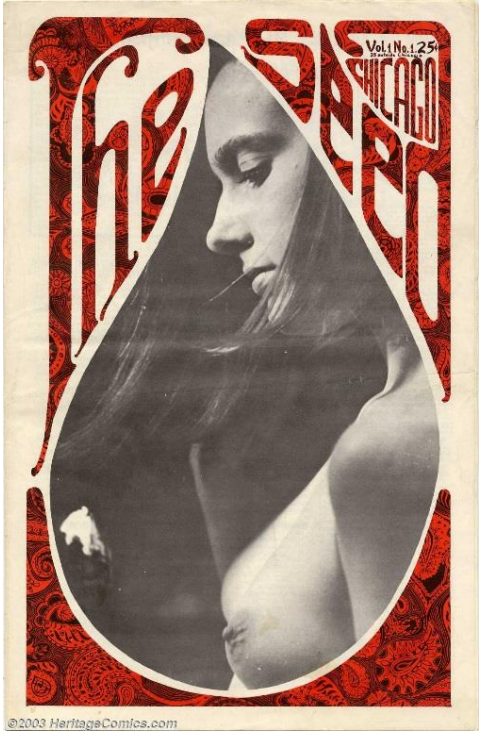

FIGURE 11: Premier issue of the Chicaao Seed (1967). idioms that overturned the rigid rules of clarity and legibility put forth by the once avant-garde 
Moderns. Through its very raunchiness it manifested the ideals of youth culture. For a brief time it was decidedly a shock to the system. But as it gained popularity, it turned into a code easily co-opted by marketers." ${ }^{59}$ Though Rolling Stone has been hesitant to admit it, they benefited greatly from the aesthetic of the underground press in conveying a sense of youthful informality. Much of this visual language was customary of 1960s design principles: Victorian bohemia and the curvature or whiplash of Art-Nouveau. These techniques were used by the underground press to visually differentiate themselves from the mainstream press by tapping into the tastes of the time.

For the underground, this distinct aesthetic was in part due to its many artistically inclined, college trained staffers, highly skilled in the art of graphic reproduction. ${ }^{60}$ For that reason, in an excerpt from Editor \& Publisher magazine an explanation of how the underground publication Oracle was designed is included: "Each Oracle page is designed as a composition first. The

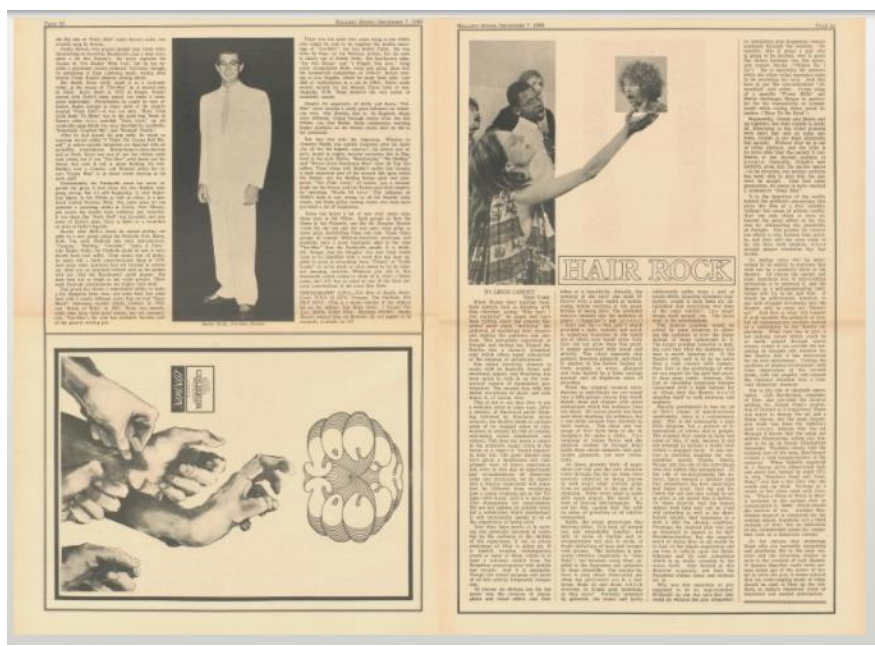

FIGURE 12: Unknown photographer, "Hair Rock" in Rolling Stone, (December 7, 1968), 20-21.

decorative area is given to an artist

while the prose goes to the typist to set patiently on Varitype inside the pattern drawn. ${ }^{\prime 61}$ In a similar way, in its use of a sinuous logo designed by psychedelic poster artist Rick Griffin, the arts and crafts style in which its photographs and texts were laid out, and its salty language, Rolling Stone favoured artful presentation over strictly informational or legible presentation. For instance in the December 7, 1968 issue of Rolling Stone, in an article titled "Hair Rock", a thin rectangular photograph of a woman

$59 \quad$ Stephen Heller, "Underground Mainstream," The Design Observer Group, accessed March 2, 2014, http://observatory.designobserver.com/entry.html?entry=6737

${ }^{60}$ McMillian, Smoking Typewriters, 48.

61 lbid., 40. 
with her arm extended sits at the left-hand side of the page, jutting out from the photograph is the woman's arm, perched upon it a second cubed photograph of a man's head [FIG.12]. The effect creates a large area of negative space located prominently above the article's title. This kind of non-functional design runs concurrent with the psychedelics of the time, specifically experimentation and perceptual abstraction over conventional forms. This aesthetic was cultivated by the underground not only through conscious design choices, but also in the inconsistencies in copy and layout.

The Kinks: An Aesthetic Choice

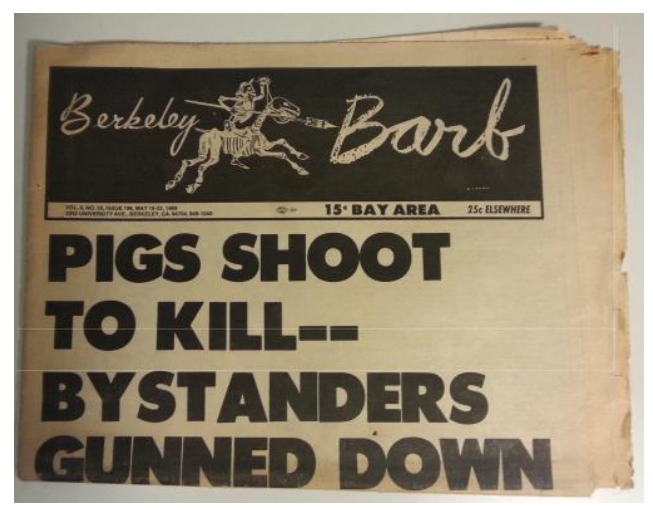

FIGURE 13: Folded front page of the Berkeley Barb (May 16-22, 1969).

Looking through issues of the Berkeley Barb, these inconsistency are showcased from the front page. For instance if we look at the May 16-22, 1969 issue the inflammatory headline "PIGS SHOOT TO KILL—BYSTANDERS GUNNED DOWN", which takes up the entire area under the masthead and above the fold (measuring $14.5 \times 27.5 \mathrm{~cm}$ ) [FIG. 13] while the photograph that supplements it sits beneath it [FIG.14]. This is quite unconventional in magazine cover design, where the visual element usually takes the position directly under the masthead, as it is more visible from a newsstand.

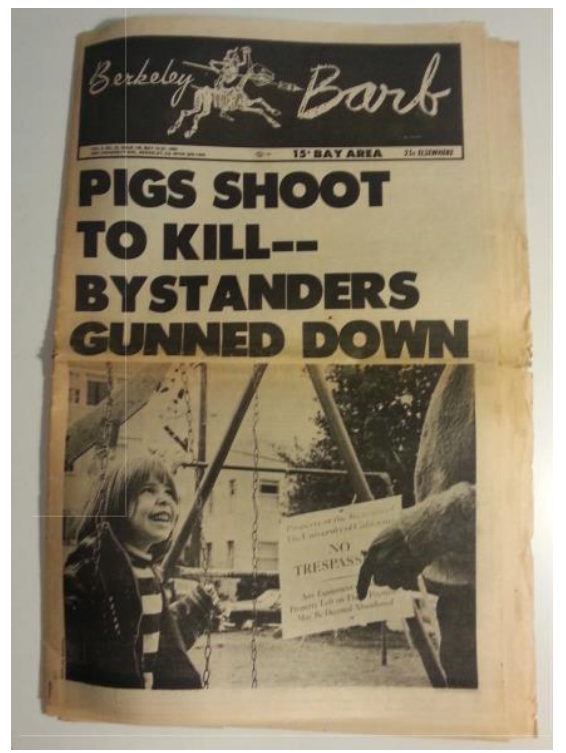

FIGURE 14: Folded front page of "PIGS SHOOT TO KILLBYSTANDERS GUNNED DOWN" in Berkeley Barb (May 16-22, 1969).

More confusing is the relationship between the photograph and the headline. The headline refers to the shooting of James Rector, a student who died from shotgun wounds inflicted by the Berkeley police on May 15,1969 . In the accompanying photograph of a young girl on a swing looking up at an adult holding 
a "No Trespassing" sign, the relationship between the headline and the photograph is not clear. Though restricted to the colour limitations of the offset press, this black and white photograph is compositionally sound, with a clear focus and a unique angle. However, rather than create a front page that is a cohesive whole, the editors felt it sufficient to publish a controversial headline with a seemingly

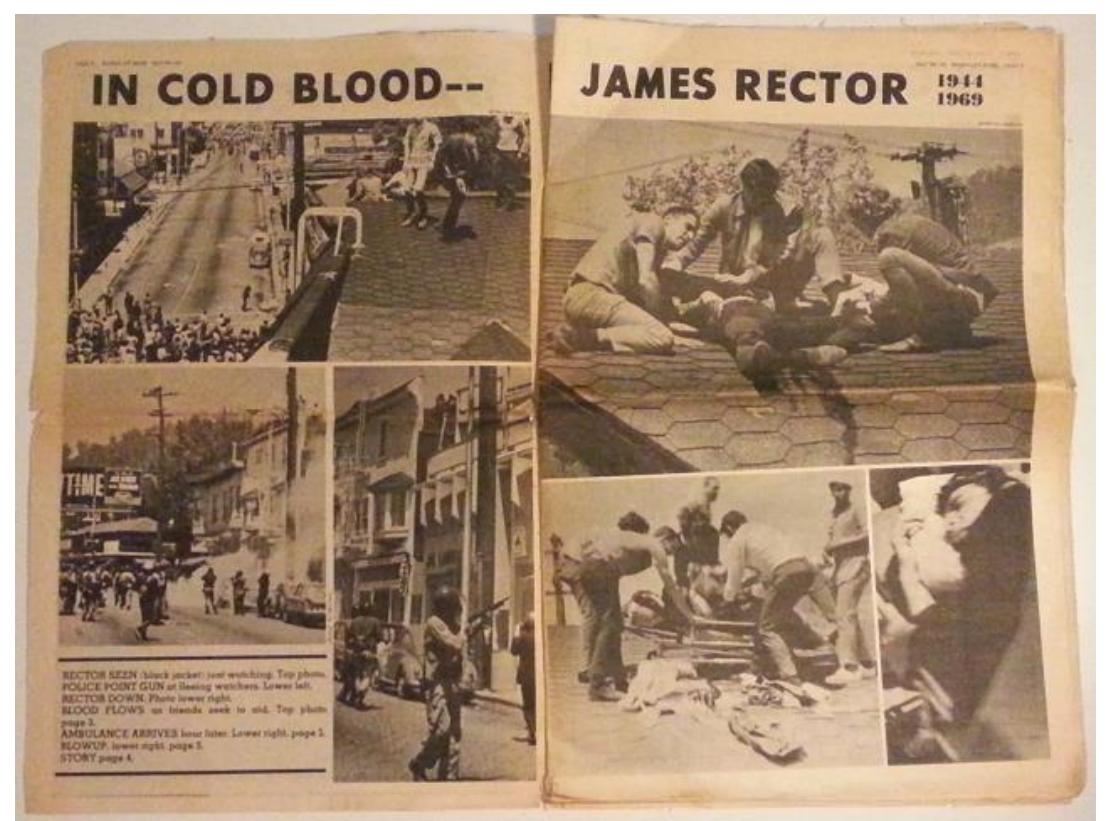

FIGURE 15: Unknown photographer, "IN COLD BLOOD-JAMES RECTOR: 1944-1969" in the Berkeley Barb (May $16-22,1969), 3-4$

unrelated, well-produced photograph. In the following May 23-29 issue, the Berkeley Barb, who regularly covered police violence in the local Southside neighbourhood, decided to provide its readers a play-by-play of the attack through the use of a picture story. Titled "IN COLD BLOOD-JAMES RECTOR: 1944-1969", six black and white, oblong and cube shaped photographs are laid out over a two page spread on page 3 and 4, chronicling the death of Rector [FIG.15]. From an initial visualization of the photographs it is unclear in what direction the eye should follow for the correct sequencing, it is therefore necessary to look to the brief captions placed on the lower left hand corner of page 3 . However these captions are problematic as the writer confuses page 3 , and page 4 in their descriptions, forcing the reader to make an educated guess as to which caption corresponds with which photograph. Because these photographs lack story-telling capacity, the reader would have no sense of the picture 
sequence without the captions. According to the inaccurate captions provided here the photographs are meant to be read counterclockwise on each page. Because the photographer could have had no idea of the direction of the story unfolding before his camera, these images, chosen in retrospect, lack much information essential to the report. As such, in two of the first three photographs on page 3, Rector is almost completely taken out of the frame. In the photograph that sits directly under the title, Rector is identified by the caption by his black jacket, otherwise his head is bisected from the frame. Similarly in the bottom right hand photograph on page 3 , in the background on a roof we can just barely make out the silhouette of two figures crouching down over a figure; the caption here just says "RECTOR DOWN. Photo lower right". The initial focus of this photograph was the helmeted police officer holding his rifle, and not the silhouette of Rector. On page 4 the narrative is much clearer, as the photographer recognized the focus of the event and is in closer proximity. According to the standards of the mainstream press, there are several design problems with this picture story; the flow of the chronology dependent upon the unnatural counterclockwise arrangement, the uneven internal margins, and the confusing captions. These kinks are pretty consistent with the discrepancies found in many underground publications which were underfunded, understaffed and placed no premium on photographic reporting. It could be argued that in some ways the photographs here are closer to the style of a mainstream magazine like Life than in Rolling Stone, as they are printed large and rectangular and there is hardly any copy. However, the blurred focus of the photographs and the attempt at scene-by-scene reconstruction aligns this picture story with two predominant trends in the underground press; casual, immediate photographs, and the fictive style of New Journalism. The Berkeley Barb further abandons these mainstream similarities in the lack of polish and attention to detail. Though some of the imperfections can be attributed to the lack of funding and editing, the front page of the May 16-22, 1969 issue of the Berkeley Barb illustrates that deliberate aesthetic choices were made that deviate from traditional guidelines of laying out a publication. 
Technological Aspects of Production: An Analysis of Rolling Stone and the Underground

Despite Jann Wenner's desire to distance himself from the underground press, Rolling Stone inevitably benefitted from the conditions that allowed the underground press to thrive. This refers to both the historical conditions ${ }^{62}$ and the technological conditions. On an operational level Rolling Stone relied heavily on volunteer labour, as well as donated furniture and rent-free office space in the loft above its printing company, Straight Arrow Publishers Inc. ${ }^{63}$ Similarly, the Berkeley Barb typically operated on a budget of $\$ 50$ to $\$ 100$ an issue (approximately $\$ 350-\$ 700^{64}$, today), with an extra $\$ 6.50$ per page for negatives and plates. When we look back at the history of the illustrated press, the startup price of Life magazine in 1936 cost Time Inc. roughly $\$ 3$ million dollars (roughly $\$ 51,420,863.31^{65}$ today). In 1967, it was relatively easy and financially feasible for an ambitious 21 year old to pilot a publication. Therefore, at this time Rolling Stone was a small operation that benefited from the technical experimentation of the underground. Based on the costs associated with mainstream magazines like Life, during the late 1960 s the news could be delivered on a much smaller scale.

What helped account for this feasibility were technological changes in printing, allowing for the rise of cheap offset printing. As David Armstrong, former editor of the Berkeley Barb, outlines:

"Prior to the 1960s, newspaper copy had to be set laboriously in hot type on a Linotype machine... [which] required technical training ... [and] money... introduction of offset printing ...made papers cheap, easy, and quick to produce. In offset

\footnotetext{
${ }^{62}$ Beginning with the magazine's founder, Wenner got his start in publishing courtesy of the underground press as a columnist for the independent, student- run The Daily Californian, writing a music column there under the pen name Mr. Jones, which was taken from Bob Dylan's "Ballad of a Thin Man." This was followed by a writing job at Sunday Ramparts. When Sunday Ramparts folded, Wenner, at 21 years old, endeavored to form his own publication with friend and veteran jazz critic Ralph Gleason mainly as a response to Ramparts refusal to cover rock $n^{\prime}$ roll in the treatment he thought it deserved. For Wenner, rock $n^{\prime}$ roll music not only described the cultural climate of the 1960s, but also fueled it. So in his opinion, it deserved to be discussed more seriously, in terms of the values that it promoted and embodied (Armstrong, 173).

${ }^{63}$ Armstrong, A Trumpet to Arms: Alternative Media in America, 173.

${ }^{64}$ Christopher Chantrill, "Total Spending for the US- Fiscal Year 1962," US Government Spending. ${ }^{65} \mathrm{lbid}$. http://www.usgovernmentspending.com/piechart_1962_US_total, accessed August 31, 2014.
} 
printing, a competent typist can use a standard typewriter to prepare copy, which is then pasted down on flat sheets photographed, and duplicated. In the middle sixties, with a few dollars, a pot of glue, a typewriter, and a handful of volunteers to write and lay out stories, several thousand copies of an offset tabloid newspaper could be printed." ${ }^{\prime 66}$

What Armstrong effectively relays is that in the mid to late 1960 s the growth of offset printing, its multiple publishing centres and easy-to-operate cold type composition equipment made small scale tabloid newspaper production a relatively small investment. Professor of Journalism Robert J. Glessing reiterates this point in his comparison of costs between using a Linotype machine for typesetting and the standard price of leasing an IBM Selectric typewriter with interchangeable typefaces; the Linotype letterpress costs nearly $\$ 20,000$, while the typewriter, just $\$ 150$ per month. ${ }^{67}$ As former Rolling Stone staff photography Baron Wolman asserts, "The only way the underground press influenced us was to show that it was possible and relatively easy to start a publication in the late sixties... from Day One, Jann emphasized we were not "underground," we were a bona fide professional publication which just happened to be printed on newsprint.." ${ }^{\prime 68}$ Despite this sentiment, a comparison of the costs associated with producing a mainstream magazine like Life further aligns Rolling Stone with the underground and not the mainstream. To illustrate, in 1936 Luce estimated the paper and printing costs for producing an issue of Life magazine were $\$ 2.2$ million dollars. This cost was so high because of the large print run, and the state of the art technology needed to print high quality photographs efficiently, and in large quantities. Life's weekly production schedule and focus on current events dictated that printing had to be done efficiently. As such, the printing company R.R Donnelley \& Sons won the contract to print Life in part because they installed heating elements on four of their rotary presses in order to insure that ink

\footnotetext{
${ }^{66}$ Armstrong, A Trumpet to Arms: Alternative Media in America, 32.

${ }^{67}$ Glessing, The Underground Press in America, 43.

${ }^{68}$ Baron Wolman, interview by Rachel Lobo, Toronto, ON, April 28, 2014.
} 
would dry quickly and not bleed. ${ }^{69}$ This kind of quality assurance is at odds with the "cheap and easy" offset printing used by the underground press and Rolling Stone. These differences in printing had a direct effect on the aesthetic of the publication produced. While the offset presses that were operated by amateurs were producing duotone photographs (at times improperly registered), Life's meticulous planning and high efficiency printing created a streamlined four-colour magazine, without the kinks associated with the underground. Though the intention of Rolling Stone was to create something markedly different in style from the underground press its production was much more aligned with the small scale printing of the underground than the logistics of the mainstream press.

\section{The Influence of Advertising: Funding the Underground and Rolling Stone}

The layout of both Rolling Stone

and underground publications like the

Berkeley Barb was at times informed by

the necessity of filling ad space. As

Glessing outlines in The Underground

Press in America, "financing an

underground publication was often times

precarious, in August 1968 the

Underground Press Syndicate asked its 79-

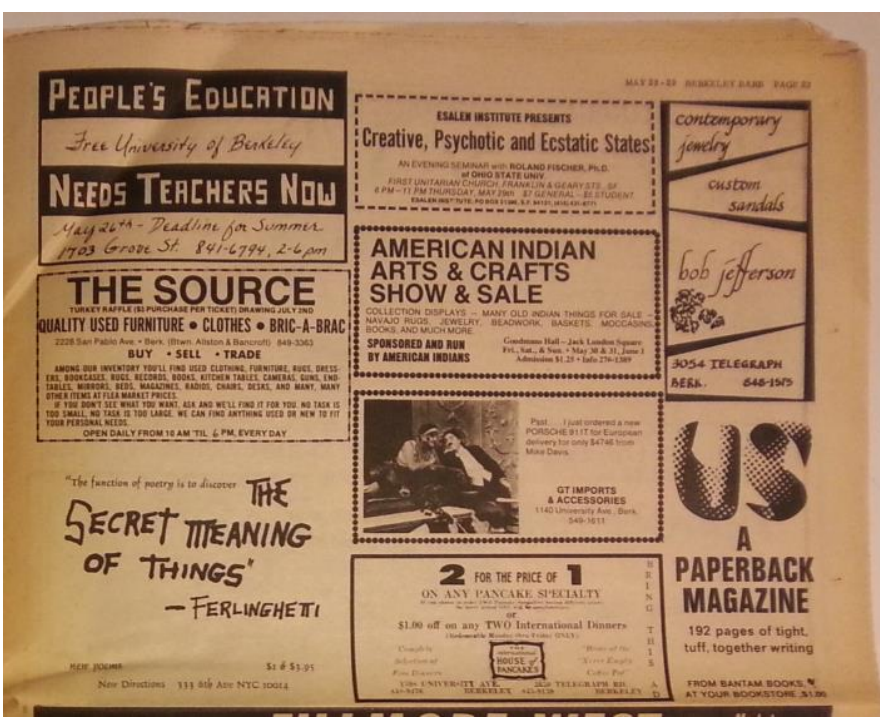

FIGURE 16: Detail of advertisements in the Berkeley Barb, (May 2329, 1969), 22-23.

paper membership, 'Are You Making A

Profit?'... only $28 \%$ replied they were, while $72 \%$ were breaking even or losing money." ${ }^{70}$ Illustrative of this, paid subscribers represented only $10-15 \%$ of the total circulation of underground publications. Local advertising was therefore integral to the survival of the underground press. Specifically, the

${ }^{69}$ Glessing, The Underground Press in America, 215

70 lbid., 96. 
Berkeley Barb "averaged 5 cents a copy from all circulation (netting \$2,500 a week)-and carried nearly $40 \%$ advertising at an open rate of $\$ 5.00$ per inch column." ${ }^{71}$ These numbers are consistent with most underground publications, where editorial content takes up roughly $70 \%$ and advertisements $30 \% .^{72}$ Visually speaking, these advertisements usually consisted of small hand-drawn notices of rock concerts, movement speeches, experimental or sex-oriented underground films, head shops, avant garde book stores, etc. ${ }^{73}$ Illustrated here [FIG. 16] these hand-drawn advertisements contributed to the

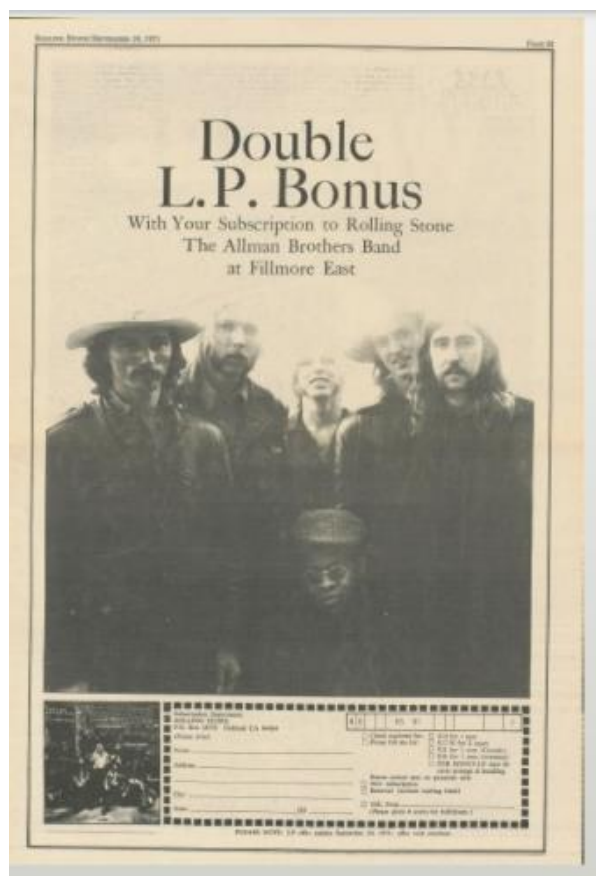

FIGURE 17: Detail of advertisements in Rolling Stone (September 16, 1971), 35.

lo-tech aesthetic of the underground, with their crooked lines and homespun feel. Like the underground editorials, advertisements featured more text than photographs. In contrast to these hand drawn ads found in the underground were the well-designed, corporate ads published in Rolling Stone [FIG. 17]. The example taken from the September 16, 1971 issue of Rolling Stone is typical of the advertisements found in the magazine, taking up an entire page, prominently featuring a photograph and with a clear organization.

A two-part feature in the New Times in 1976 on Wenner and Rolling Stone describes the relationship between the magazine and large record companies: "Wenner ... obtained advances against future advertising of more than $\$ 25,000$ each from Atlantic and Columbia records... Columbia's president Clive Davis had Columbia's art department design a direct mail campaign for the magazine. At one point, Rolling Stone's advertising salesmen were working directly out of Columbia's offices."74

\footnotetext{
71 lbid., 90.

72 Ibid., 91.

73 Ibid.

${ }^{74}$ Armstrong, A Trumpet to Arms: Alternative Media in America, 176.
} 
This tightknit relationship between Rolling Stone editors and record executives directly influenced the editorial content, in a way that proponents of the underground would find morally reprehensible. They could not raise enough revenue, and their ideological opposition to engage with the mainstream economic system eventually led to their demise.

\section{Some Parallels in Art Photography}

The alternative content, layout, and photography used at Berkeley Barb as well as at Rolling Stone certainly responded to the cultural tastes of the 1960s. More aptly photographer Nan Goldin reminisces "I felt it was a challenge to my generation... to overthrow Life magazine and [its] whole system of communicating with America." ${ }^{\prime 75}$ As illustrated in the Introduction, Life's system of communication was indeed breaking down, an event that corresponded with the socio-political landscape of America in the 1960s. Much like the acid-tongued commentaries of New Journalism, photography described American life through satirical or casual representations.

For instance the photography of Ed Ruscha in the early 1960s displays an amateur aesthetic, neither purely documentary nor purely artistic, their subject matter was stereotypical and banal, with motifs drawn mostly from ordinary outdoor sites in Southern California. ${ }^{76}$ In Ruscha's 1963 book Twentysix Gasoline Stations the artist approached his subject matter as found objects or built landscapes, documenting 26 gasoline

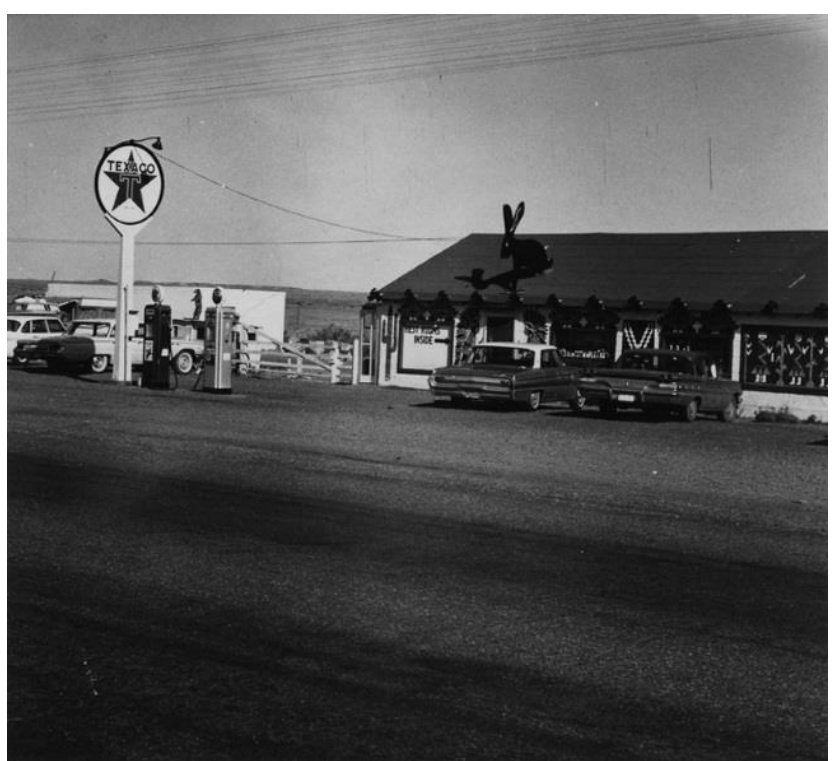

FIGURE 18: Edward Ruscha, Texaco, Jackrabbit, Arizona, from Twentysix Gasoline Stations, 1963. Gelatin silver print.

\footnotetext{
${ }^{75}$ Gennari, “Bridging Two Americas: LIFE Looks at the 1960s,” 267.

${ }^{76}$ Sylvia Wolf. Ed Ruscha and Photography (New York: Steidl Publishers, 2006), 11.
} 
stations on the highway to Los Angeles with a $2 \frac{1}{4}$-inch-format Yashica camera. ${ }^{77}$ If we look at Texaco, Jackrabbit, Arizona [FIG.18] from the series the frame of the photograph cuts off one of the main structures, and appears to be taken at an angle. Adding to this amateur aesthetic, the asphalt of the highway takes up the entire foreground, occupying more than half of the frame. Describing his aesthetic Ruscha explains, "I was after that kind of blank reality that the subject matter would present."78 . A product of its time, the photography that was featured in the Berkeley Barb and Rolling Stone magazine adopted this style of loose representation, where unposed and casual documentation was favoured. To illustrate, in the October 26, 1968 issue of Rolling Stone, accompanying a review of Hunter Davies The Beatles: The Authorized Biography are several photographs of The Beatles [FIG.19]. Each photograph is seemingly candid, and at times the subject of the photograph is unclear. Take for instance the tightly cropped photograph in the bottom left of the spread of George Harrison and Ringo Starr. Though the socalled action displayed in the photograph is of Harrison holding out a drumstick to the cymbal, the photograph is unremarkable-both Beatles have little expression on their faces. However the photograph presents the minutia of everyday life for the Beatles, and in this way it

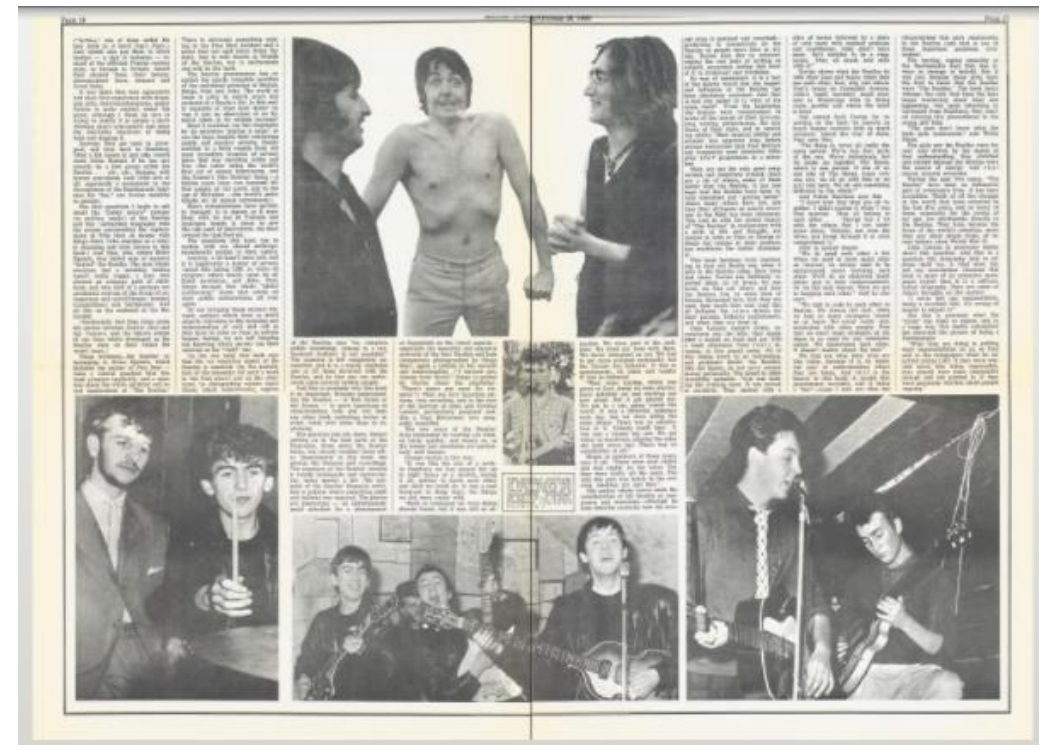

FIGURE 19: Stephen Goldblatt, "The Beatles" in Rolling Stone (October 26, 1968), 16-17.

aligns with a more relatable representation. Rolling Stone staff photographer Baron Wolman describes

\footnotetext{
77 Wolf, Ed Ruscha and Photography, 15.

78 "The Genius of Photography: Ed Rushca." BBC Television, accessed June 15, 2014, http://www.bbc.co.uk/photography/genius/gallery/ruscha.shtml.
} 
this kind of photography that was championed by the magazine: "The style was 'real'. What did the concert really look like? What was it like to have been there? To have seen a particular musician perform? For portraits, the same: who was the musician, what did he or she really look like."79 For Rolling Stone this looseness, reminiscent of the underground, functioned metaphorically as a signifier that opposed the polish of the mainstream press.

${ }^{79}$ Baron Wolman, interview by Rachel Lobo, Toronto, ON, April 28, 2014. 


\section{Rolling Stone's Cover Photography: An Evolution Toward the Mainstream}

"We take all kinds of pills that give us all kind of thrills

But the thrill we've never known

Is the thrill that'll getcha when you get your picture

On the cover of the Rollin' Stone

Wanna see my picture on the cover

Wanna buy five copies for my mother

Wanna see my smilin' face

On the cover of the Rollin' Stone" 80

In his lyrics to the now infamous 1972 Dr.Hook song "The Cover of Rolling Stone," Shel

Silverstein alludes to the cultural significance of Rolling Stone's cover art. Being photographed for the cover of Rolling Stone is now seen as a benchmark in the career of emerging entertainers, and is often used as a well-crafted publicity stunt by the entertainment industry. Today the cover is often associated with an exuberant and provocative portrait, but tracing the lineage of cover photography at Rolling Stone reveals more humble beginnings. Starting with the magazine's premier issue on November 9, 1967 to its last issue within the scope of this project, the December 21, 1972 issue, we see a slow evolution from unpremeditated black and white portraiture used on the covers of underground publications toward the highly produced, coloured portraits seen on mainstream magazines. This evolution runs congruent with larger trends in photography, magazine design, and album cover art. The casual documentation used within Rolling Stone's editorials during the 1960s can also be seen in their cover photography from the era. This aesthetic also evolved based on the technical capabilities of offset printing, which drove certain design choices like the addition of colour and the use of linework. The choice to feature this kind of casual representation on the magazine's cover clearly demonstrates the faith the editors at Rolling Stone had in this aesthetic. Essentially, Rolling Stone was establishing new visual standards based on the model that underground culture provided in their informal, or lo-tech aesthetic.

80 Shel Silverstein, "The Cover of the Rolling Stone" (song lyrics), Accessed May 2, 2014, http://www.azlyrics.com/lyrics/drhook/thecoveroftherollingstone.html 


\section{Casual Documentation: Subject over Photographic Clarity}

More visually akin to the front page of a

newspaper, the first three issues of Rolling Stone are

only three of eight in the magazine's history that

include copy on the covers [FIG.20]. Though we

associate magazine covers with the juxtaposition of a

full spread colour photograph framed by headlines,

like a newspaper black and white photographs and

copy are laid out over the cover spread in

Rolling Stone's 1967 issues. In this way the

publication was aligned with underground

publications like the Berkeley Barb [FIG.21], in its

intricate masthead, dense copy, prominent visual

component, and tabloid format.

In its first three issues the photograph in

Rolling Stone's cover takes up the majority of the

page, with each photograph's point of interest sitting

above the fold, directly under the title. What can be

gleaned from close examination of the photographs

used in the 1967 covers, is that the selling point here

must have been the subject of the photograph and

not the quality of the photograph. Quality here refers

to its adherence to the craft elements of

photojournalism, specifically a clear focus, proper

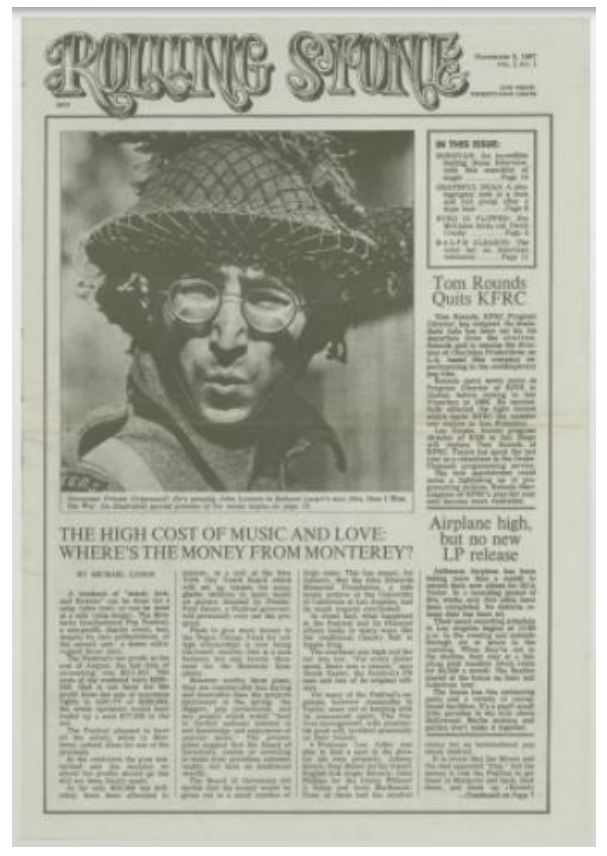

FIGURE 20: Unknown photographer, cover of Rolling Stone (November 7, 1967).

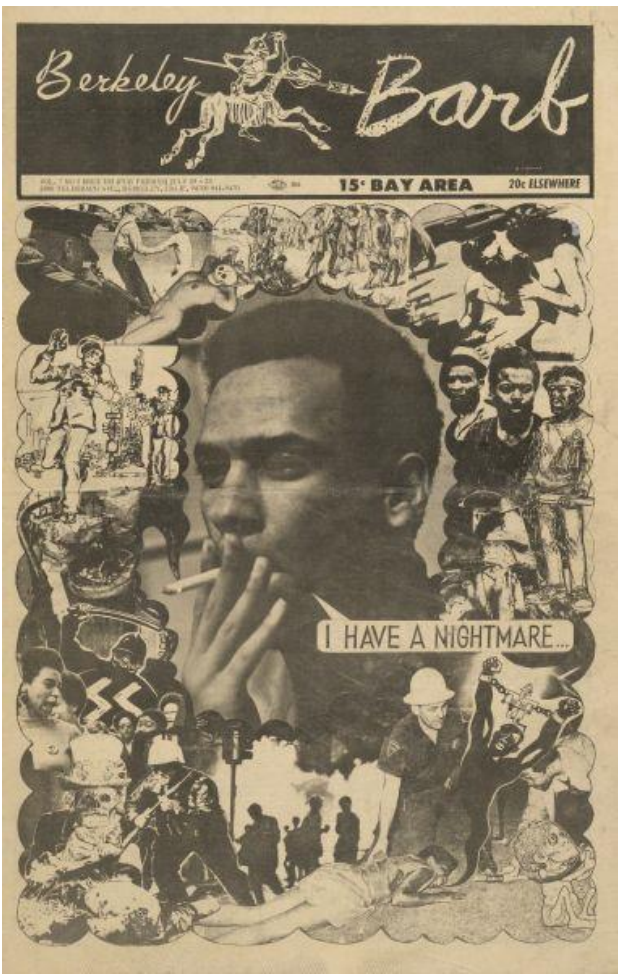

FIGURE 21: Unknown photographer, cover of the Berkeley Barb, (July 19, 1969). 
framing and an easily identified subject. In correspondence with then staff photographer Annie Leibovitz in 1982, Jann Wenner discusses this idea: "The basic rule - salability on newsstands depends, insofar as the photo, on subject recognizability - is not open to discussion... The elements that do - and don't go into recognizability are obvious - the standard facts of big heads, open eyes, strong colors, etc.

....and the natural exceptions are also obvious. A bad

cover due to limited or difficult recognizability ... cuts

newsstand sales somewhere between 25,000 to 50,000

copies, which translates to a $\$ 15,000$ to $\$ 30,000$

direct loss in company profits." ${ }^{11}$ Though outside the scope of this research Wenner's comments are a result of four years within this chronology. For instance in the magazine's first issue, John Lennon is featured on the cover wearing military fatigues, a photograph taken on the set of Richard Lester's film How I Won the War. The photograph appears to be candid, the wide shadows

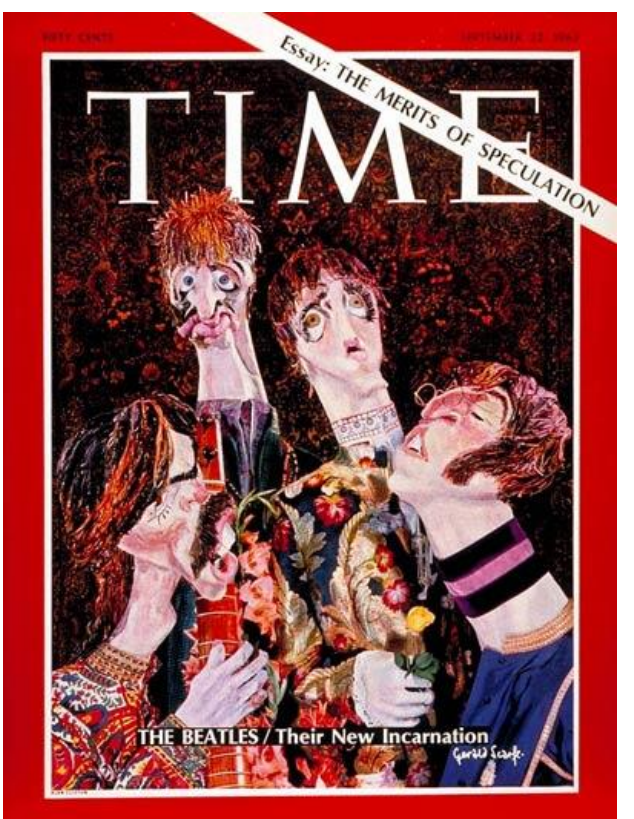

FIGURE 22: Gerald Scarfe, cover of TIME magazine, (September 22, 1967).

cast by his glasses and his squinted eyes indicate that Lennon stands facing the sun. His glance is directed away from the camera, and his lips are pursed as though he is whistling. In 1967 the public was curious about the nature of the music the Beatles would be producing -the press often speculating that this was a transformative or new period in their career. In the case of the September 22, 1967 issue of TIME magazine [FIG.22], an illustration of The Beatles over a photograph was enough to attract readers. At this particular moment in time, featuring John Lennon on the premier issue of a magazine was a safe bet regardless of the clarity of the photographic representation. Therefore, the selling point of the photograph used on the November 9, 1967 cover is the content and aesthetic of the photograph (or

\footnotetext{
81 “Little Brown Miscelleanea: I am the boss," TIME Lightbox Tumblr, Accessed May 1, 2014.
} 
"recognizibility" as Wenner describes it) and not its tonal fidelity or clarity - a more casual photographic representation of a Beatle was enough to move issues. This aesthetic aligned nicely with the hallmarks of amateur photography—off-centred framing, crude lighting, and banal scenery.

In a similar fashion, in the magazine's second issue, a tightly cropped, out of focus, photograph of Tina Turner performing onstage with the Ike \& Tina Turner Revue occupies the majority of the cover [FIG.23], with only a thin column of copy flanking the photograph. The photograph is

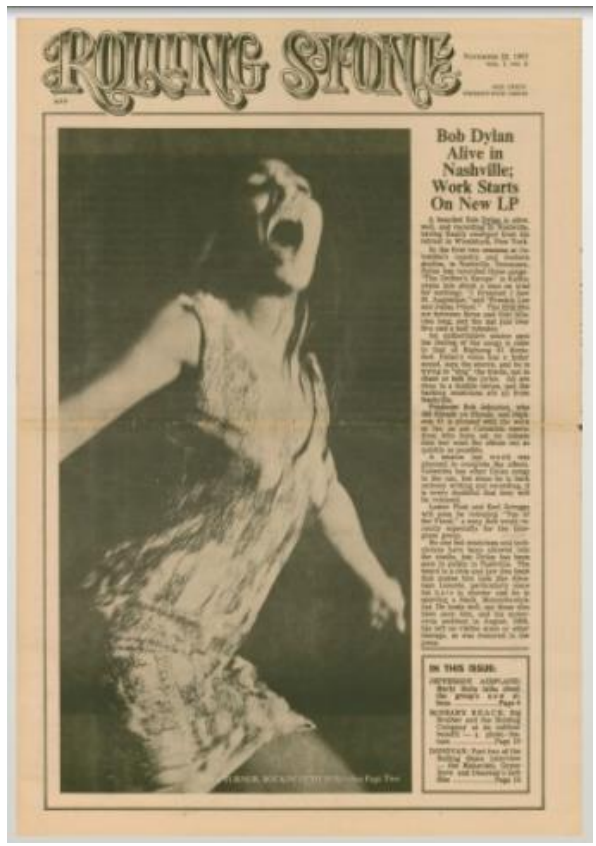

FIGURE 23: Baron Wolman, cover of Rolling Stone (November 23, 1967).

dynamic, with Turner's mouth open wide mid song, and her arms out on either side. Like the photograph of Lennon, Turner does not look at the photographer-the focus here is the curvature of her body and the intensity of her facial expression. Though the magazine gave her performance a paltry review, in their editorial they comment on the singer's dynamism and appearance: "She comes in this very short miniskirt, way above her knees, with zillions of silver sequins and sparklers pasted on it." 82 The selling point of the cover is clearly Turner's sex appeal, a method that aligns with multi-millionaire publisher William Randolph Hearst's philosophy when it came to magazine covers: "Show me a magazine cover with a pretty girl... and I'll show you a magazine that sells." Pretty girls had been a prevailing subject for magazine covers since the beginning of the illustrated press. Though the cover photograph of Turner is blurred, the illusion of dynamism that the curves of her body produce and her impassioned facial expression tap in to the same selling point as more focused, mainstream covers: female sexuality. While in the mainstream press used this as a selling point through clearly rendered

\footnotetext{
82 Jann Wenner, "Random Notes," in Rolling Stone, November 7, 1967, 2.
} 
portraits, at Rolling Stone a similar, more subtle effect is achieved in the abstraction of the photograph's blur. This blurred perception aligned not only with the amateur aesthetic of the time but also the aesthetic of psychedelic art, which related the idea of distortion with getting out of one's head or bending consciousness. ${ }^{83}$ .Overall, like the cover photograph of Lennon, the abstractive quality alludes to a loosening of the conventions photographic representation. The final issue of 1967

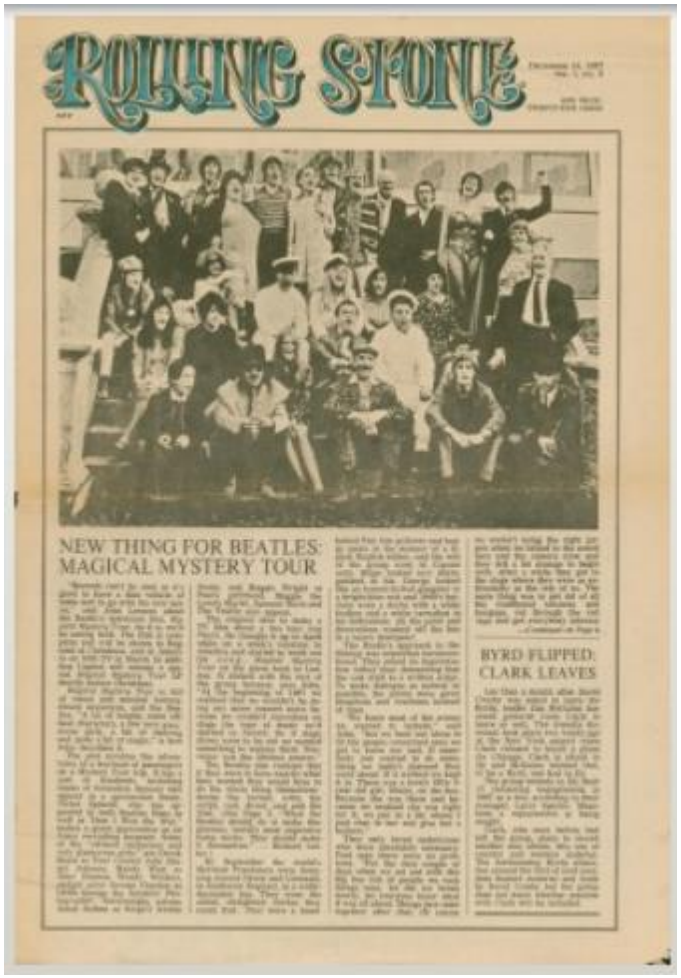

FIGURE 24:Unknown photographer, cover of Rolling Stone issues (December 14, 1967).

features The Beatles and their entourage posed from their Magical Mystery Tour, in a group portrait akin to class photo [FIG.24]. While some sitters face the camera, a number of them face the left, indicating that a second cameraman was capturing a similar shot. The lack of uniformity here effectively arrests a scene that is both fun, and a tad disorganized-referencing the cover art work for their album Sgt. Pepper's Lonely Hearts Club Band. As mentioned, the Beatles had a devout following and the press exploited this regularly. This issue of Rolling Stone was published only six days after The Beatles debuted the Magical Mystery Tour, a six-song soundtrack to the 1967 film of the same name. The headline that accompanied the photograph and article reads "New Thing from the Beatles: The Magical Mystery Tour", a similar coverline is used on the cover of Life magazine, "The New Far-Out Beatles" [FIG. 25], and on the cover of Time magazine, "The Beatles: Their New Incarnation." The likeness in coverlines 
between the stalwarts of photojournalism produced by Time Inc. indicated that there was a widespread appetite for The Beatles, and that music-journalism and more generally rock $\mathrm{n}^{\prime}$ roll music was a widespread phenomenon. This cover, and its two predecessors are indicative of an early trend in Rolling Stone covers: casual documentation akin to tabloid newspapers over traditional portraits. To reiterate, in her chapter "Front-page Problems" Vitray discusses the type of photography commonly used in tabloid format newspapers: "Surprise is a vital factor... a daring action photograph offers enough surprise in itself... [playing] it large enough to enable it to make its full effect." 84 Therefore, the editors of Rolling Stone were adapting a previously successful model seen in mainstream publications by adding a more casual aesthetic that stayed

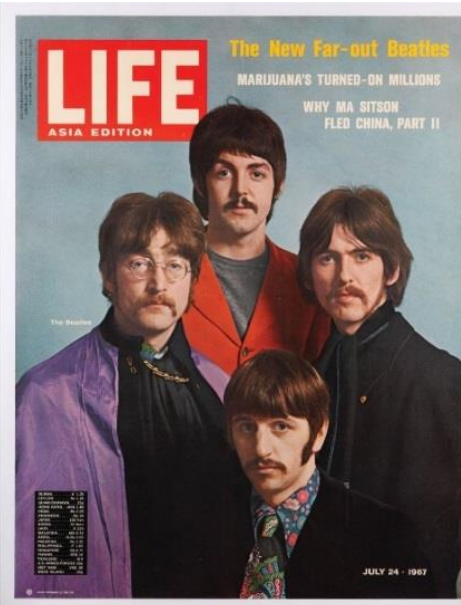

FIGURE 25: Unknown photographer, cover of Life magazine (July 4,1967). faithful to their fan base.

What can be gleaned from these three issues is that a richly coloured, finely produced
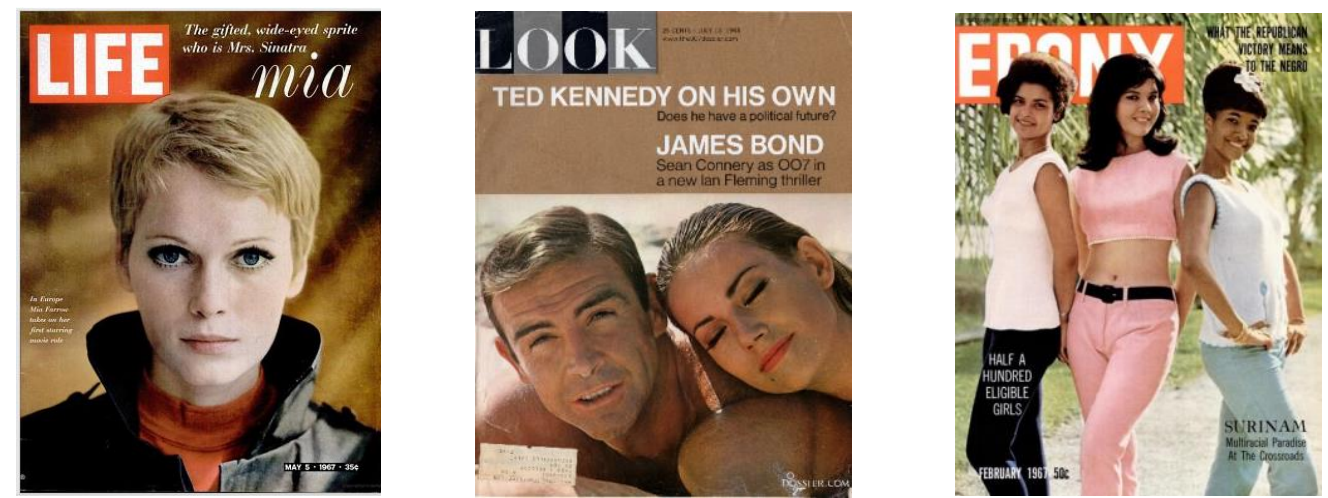

FIGURE 26, 27, 28: Cover of Life (May 5, 1967), Cover of Look (July 13, 1965) and the Cover of Ebony (February 1967).

photograph aligned with the craft elements of photojournalism, was not necessary to sell issues to the Rolling Stone demographic in the late 1960s. This is not to say that the quality of cover photograph at

\footnotetext{
${ }^{84}$ Vitray, Mills et al., Pictorial Journalism, 274.
} 
Rolling Stone was sub-par, but rather the casual aesthetic was an attractive selling feature for the Rolling Stone audience, as it emerged as a popular aesthetic in the photography of Ruscha.

This aesthetic is very democratic in nature and can be traced to the mass photography of the late 1880 s and the era of the Brownie camera. In both eras this casual aesthetic represented a moment in flux, including all of its marginalia without the pretentions of art photography. This aesthetic and the salability of the subjects is what sold issues of the magazine As Baron FIGURE 29: Robert Altman, cover of
Rolling Stone magazine (October 18, 1969).

Wolman explains, "before MTV, before the Internet, people got

their visual information about music and musicians (and politics) from the harmony of pictures and words - Rolling Stone was virtually their only source." ${ }^{85}$ In this way the cover acted as a window into the kinds of subjects addressed within the pages of the magazine. To illustrate, if we look at the photography used on the covers of magazines like Life, Look, or Ebony [FIG.: 26, 27, 28] during the late 1960s we see a completely different trend, their photographs are vividly coloured, capturing the most attractive elements of each subject. In the case of Life and Ebony the subdued coverlines are moved to the margins of the page framing the cover photograph's point of interest.

\section{The Influence of Album Covers on Design and Photography}

In terms of design, album cover art also had a strong influence on the aesthetic of Rolling Stone's cover photography-specifically in the use of negative space and decorative elements. Negative space on the Rolling Stone's covers was used to effectively place coverlines that framed the cover image, and the lack of heavy copy made the overall look much more polished and professional [FIG.29]. Traditionally, in tabloid newspapers negative space also served to punctuate an action shot, "by paring

\footnotetext{
${ }^{85}$ Baron Wolman, interview by Rachel Lobo, Toronto, ON, April 8, 2014.
} 

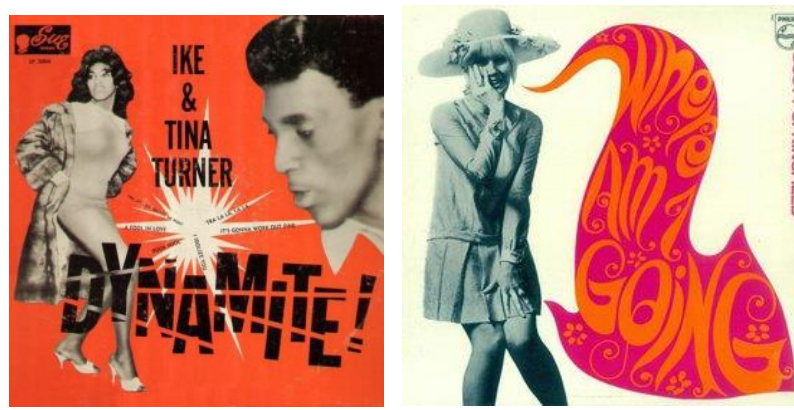

FIGURE 30, 31: Ike \& Tina Turner "DYNAMITE!" (1963), Dusty Springfield "Where Am I Going" (1967). off background that is not needed to tell the story, the action of the picture can be blown up to the maximum size." 86 Accordingly, in Ike and Tina Turner's album cover for "DYNAMITE!" [FIG.30], Dusty Springfield's album cover for “Where Am I

Going?"[FIG.31] and the cover photograph of David Crosby in Figure 29, action and immediacy are conveyed by emphasizing the pose of the subject. Ultimately, the silhouetting of figures and omitting of background detail takes away the purely informational quality of the photograph in favour of a more representational quality. As the first three issues demonstrate, Rolling Stone was using familiar subject matter when it came to producing their coverswhat differed was their approach. This lack of formality in visual messaging aligns nicely with the album cover art
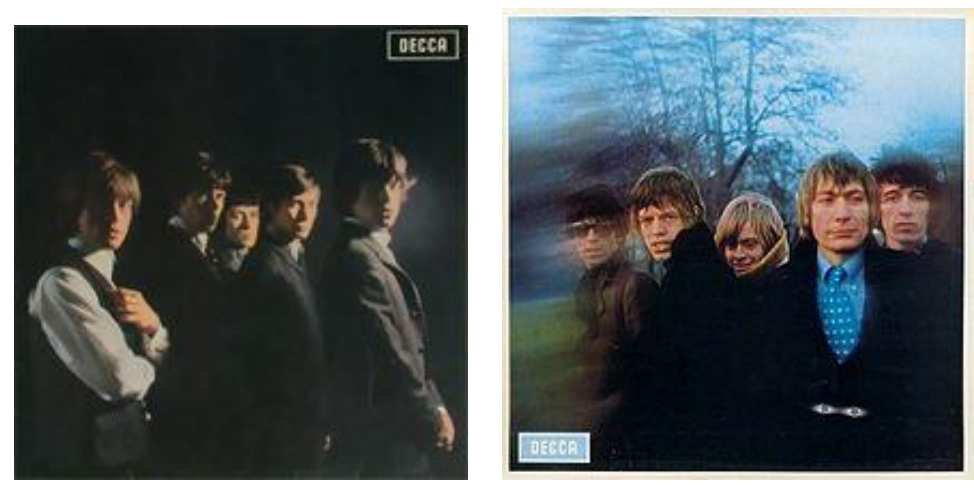

FIGURE 32, 33: Unknown photographer "The Rolling Stones" (1964), Gered Mankowitz, "Between the Buttons" (1967).

of the time. The imagery featured on the sleeves of vinyl albums served a similar marketing function as the cover of a magazine, the examples below indicate that having a clearly reproduced photograph was not as significant during this time. The attitudes associated with psychedelic rock music ridiculed the uniformity and formality of the early 1960s. It is clear from the album art of popular acts of the time like The Rolling Stones that these attitudes influenced their taste in visual culture as well [FIG.: 32, 33]. The cover photography featured on the bands' self-titled 1964 debut album is a highly produced studio portrait, with careful lighting and an even frame. While the 1967 album, Between the Buttons,

\footnotetext{
${ }^{86}$ Vitray, Mills, et al., Pictorial Journalism, 274-275.
} 
showcases signs of distortion. Specifically, photographer Gered Mankowitz created a camera filter constructed of black card, glass and Vaseline in order to create the effect that the band was dissolving into their surroundings. ${ }^{87}$ In both these album covers and Rolling Stone's 1967 cover photography, distortion is created through blur or the fibrous texture of the uncoated newsprint. .

Looking to the Grateful Dead, and Crosby, Stills, Nash and Young album covers [FIG.: 34, 35], the use of intricate lines or border lines also appears on the cover of Rolling Stone magazine.

Then Art Director Robert C. Kingsbury introduced these lines to the magazine's covers in order to add a neo-Victorian or Art Nouveau spin, a popular design feature in the 1960s. This design

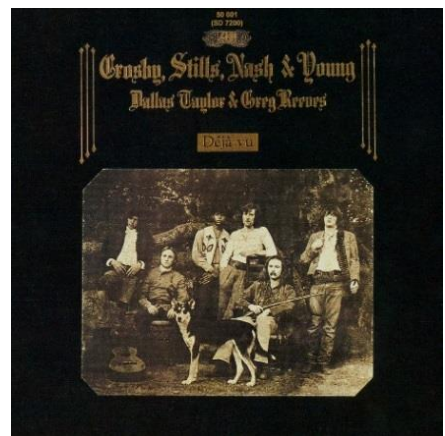

FIGURE 34, 35: Grateful Dead "Workingman's Dead" (1970), Henry Diltz, Crosby, Stills, Nash and Young

choice was very much influenced by the poster art of the time,

with their decorative elements and development of pattern [FIG.36]. Posters such as the one produced by Mouse Studios for The Grateful

Dead [FIG. 37] were usually low budget projects, that had all the signifiers of the counterculture; playful curvature, decorative lettering, and a sense of symmetry.
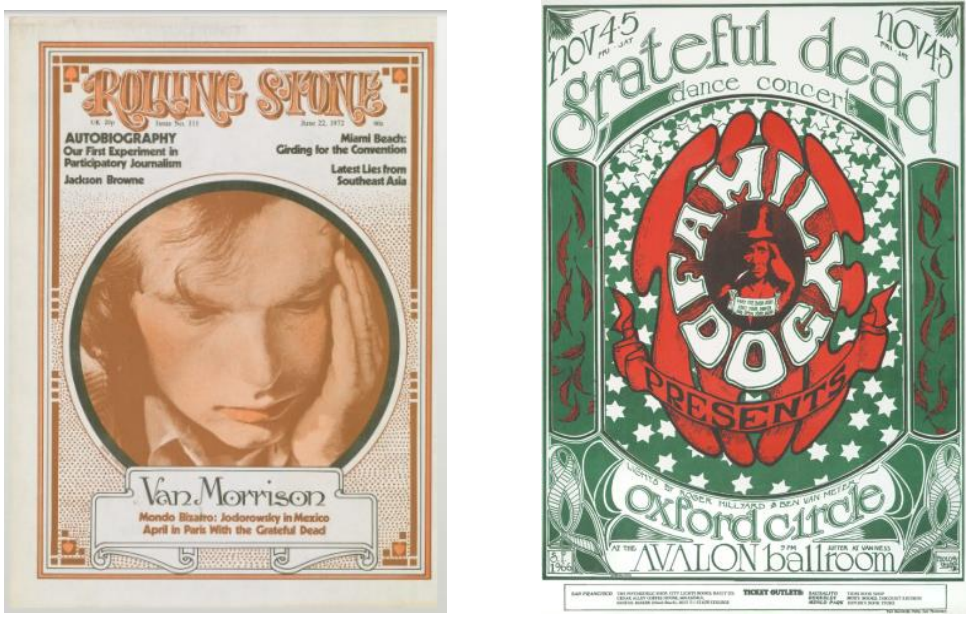

FIGURE 36, 37: Annie Leibovitz, cover of Rolling Stone magazine (June 22, 1972), Poster bv Mouse Studios for the Grateful Dead (1966)

87 Oliver Craske, Rock Faces - The World's Top Rock ' $n$ ' Roll Photographers and Their Greatest Images (Sussex: Rotovision, 2004), 89. 
Toward the Mainstream:The Role of Offset Printing, and Finances

As mentioned in the Introduction, the rise of offset

printing enabled the underground press and Rolling Stone to

develop during the 1960s. However, as the producers of Rolling

Stone became more acquainted with this technology and the

magazine gained investors more risks could be taken

aesthetically. Therefore while earlier issues of the magazine have

the lo-tech look of the underground, the later years within the

scope of this research gesture more toward the design features of

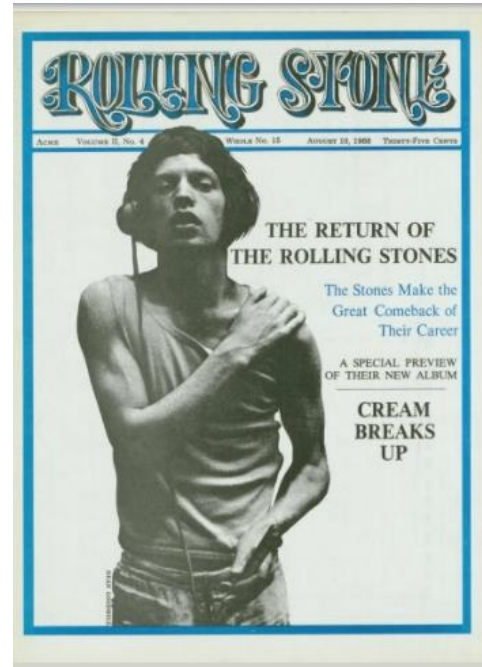

FIGURE 38: Dean Goodhill, cover of Rolling Stone (August 10, 1968)

a mainstream publication. Regardless of the size, and the environment in which the photograph was taken, what remains is the relaxed aesthetic of the photographs.

The first five issues of Rolling Stone produced in 1968 use the same format as the 1967 issues, after this point we see a shift toward more colour, larger photographs, and less text featured on the cover-akin to more mainstream publications. Staff photographer Baron Wolman attributes this shift to the fact that when sitting on a newsstand the issues with copy on the cover were not selling. To fix this problem Rolling Stone staff decided to sit the four-fold publication on its side, so it mimicked the shape and style of a magazine. ${ }^{88}$ It could be said that it was at this point that visually speaking Rolling Stone was outgrowing its underground roots. Not surprisingly 1968 was the year that Straight Arrow Press acquired an additional $\$ 40,000$ from investors. ${ }^{89}$ The kinds of photographs used on the cover were sharper, using the technical capabilities of the duotone format to integrate splashy colours. Though in small-offset printing numerous colours can be applied to a single sheet, when multiple colours are applied the chances of fault increase greatly, as colours could bleed into one another. ${ }^{90}$ In its first eight

\footnotetext{
${ }^{88}$ Baron Wolman, interview by Rachel Lobo, Toronto, ON, April 28, 2014.

89 "Wenner Media, Inc. History."

$90 \quad$ Harry T. Chambers, The Management of Small-Offset Print Departments (London: Business Books Limited, 1969), 168.
} 
issues Rolling Stone used colour scarcely-applied only to accentuate the masthead. It is in 1968 that a thick coloured border is introduced to the cover's design, usually mimicking a colour element used elsewhere on the cover [FIG. 38]. The colour border would be considered 'line work' in offset printing, "a term used to denote any work of solid area and line which does not contain intermediate tone, and consequently has no variation of light and shade." ${ }^{91}$ In printing line colour work, variations in colour value are usually undetectable, making it a less cumbersome and more feasible way of producing colour through offset printing.

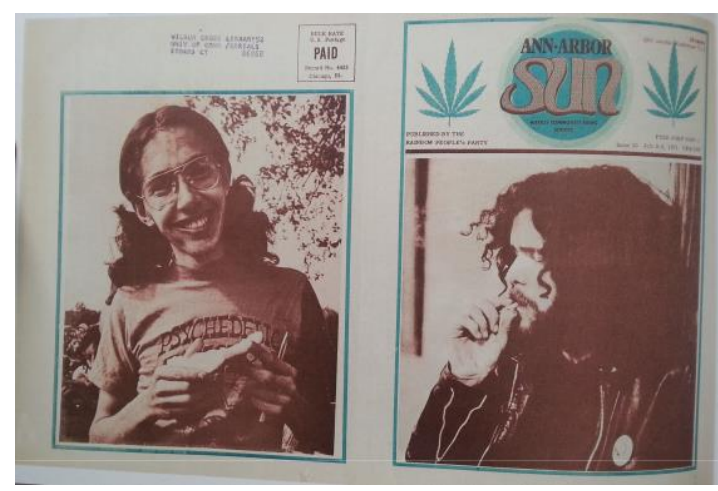

FIGURE 39: Front and back covers of Ann Arbor Sun, July 2-8, 1971.

For this reason, we can assume that the

thick monochromatic borders were integrated into Rolling Stone's covers because of their relative technical ease. Likewise this same reason, thick, coloured borders can be seen regularly on the cover of underground publications [FIG.39]. The colour limitations and uncoated newsprint used for Rolling Stone's pages abstracted its photography in a way that looked more holistic-contradicting the realistic effect of the photography.

In 1969 Rolling Stone was distancing itself from the underground press by the kinds of photographs that they featured on their cover. While the underground press would publish a myriad of different photographs - from grainy candid shots to well-lit portraits, Rolling Stone began featuring more tightly cropped head shots on its cover [FIG. 40]-similar to the style of

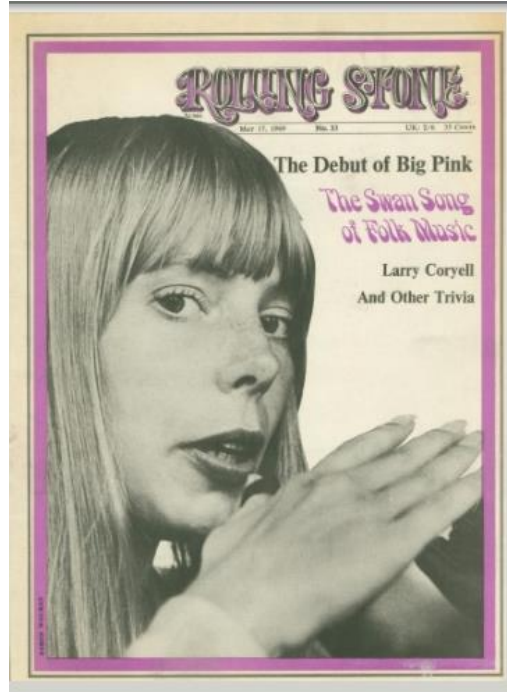

FIGURE 40: Baron Wolman, cover of Rolling Stone (May 17, 1969).

\footnotetext{
${ }^{91}$ Andy Warhol, Andy Warhol's Exposures (New York: Putnam Publishing Group, 1980), 34.
} 
mainstream publications like Life. Whether action shots or studio portraits the cover photograph now regularly featured a musician from the waist up. However, in its studio portraits Rolling Stone was beginning to develop its own style. While Life's covers had long favoured highly constructed, out of studio portraits and the underground refused to publish anything that looked contrived or unoriginal, Rolling Stone was beginning to generate cover photographs from photoshoots. Though this produced an aesthetically controlled product seemingly unaligned with their penchant for casualness, in almost all cases the pose of their sitter indicated looseness and freedom of expression. Rolling Stone's compositionally sound photographs with clear focus were now the main selling factor of an issue, as coverline regularly referenced the cover story with no mention of any content beyond this.

So far there is a decisive shift in cover design to accommodate a larger feature photograph. 1970 marked the year where photographs took up the majority of the cover, occupying the entire bordered area with little negative space was being used [FIG: 41]. This trend runs concurrent with trends in most major magazines at the time, marking a further rift between Rolling Stone's alignments with underground publications [FIG: 42].

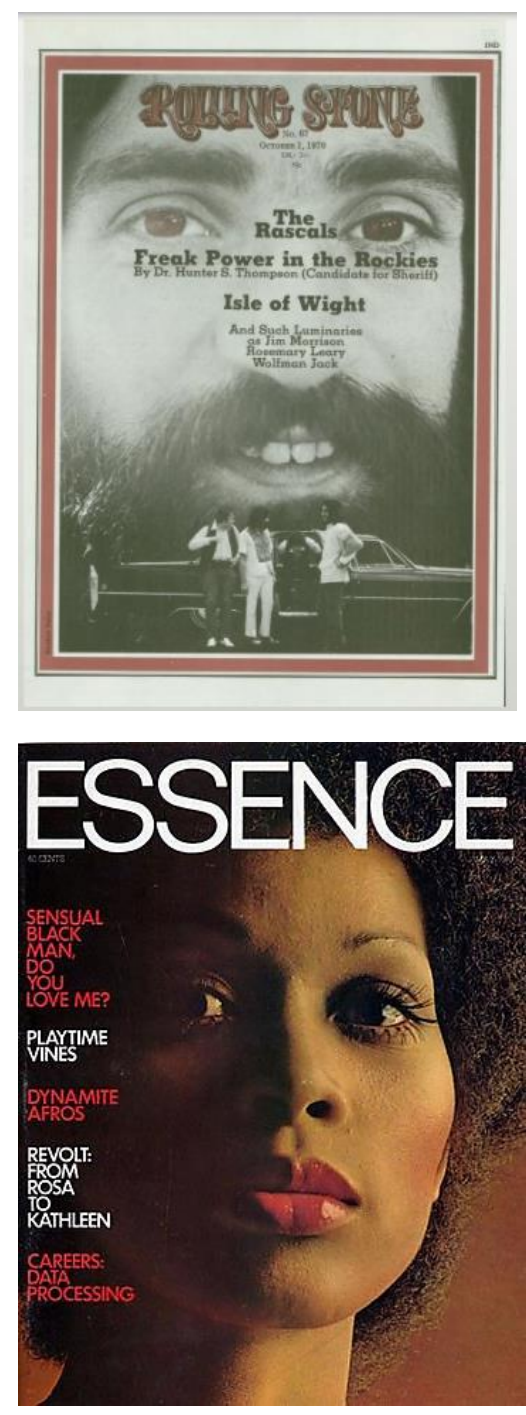

FIGURE 41 (top): Stephen Paley, cover of Rolling Stone issue (October 1, 1970).

FIGURE 42 (bottom): Unknown photographer, cover of ESSENCE (May 1970). Making room for a larger photograph meant that the number of coverlines began declining in 1970, by the end of the year only two appeared on each cover-generally justified to the left of the photograph. Though previously, colour had largely been relegated to the border and masthead, in 1970 with 
photographs taking up most of the cover real estate, editors found refreshing ways of adding colourusually by singling out a detail of the photograph or having a colour screen cast over the entire photograph [FIG.43]. For the first time, multiple colours were used on a single cover. This process required more care to be undertaken by the printer, and consideration by the designer; "provided there is white space between the colours and there are no large areas of solid colour, line colour is easy compared to other processes, but it still needs more care than printing one colour only." ${ }^{\prime 2}$ This process also requires precise registration (the exact printing of one colour with another). In a duotone process this means "printing one colour over the other

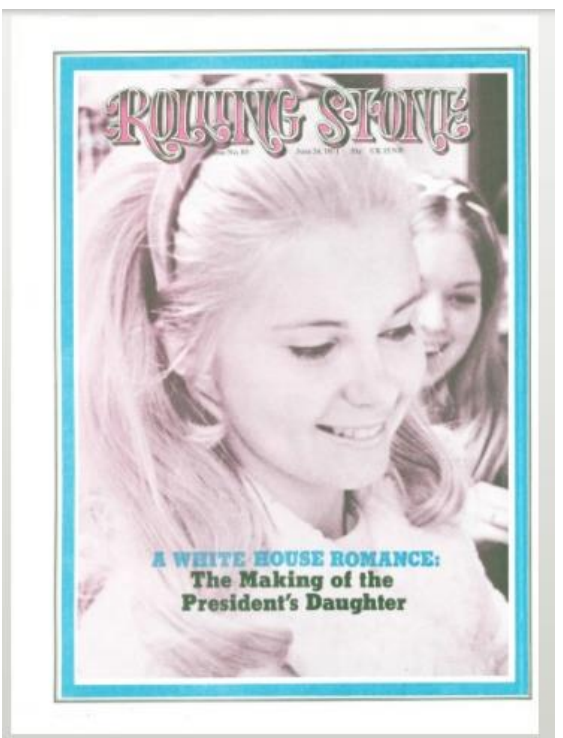

FIGURE 43: Unknown photographer, cover of Rolling Stone (June 24, 1971).

so accurately that where two colours coincide over an area the dots are printed exactly on top of each other. ${ }^{\prime 93}$ Therefore to accurately showcase multiple colours on the cover, experienced printing operators were required. It is no surprise then that these printing innovations at Rolling Stone corresponded to creation of a new publishing arm at Straight Arrow Publishers, established to publish paperback publications related to the magazine ${ }^{94}$. Though still in its infancy, Rolling Stone was establishing itself as an institution, with its larger photographs, and use of colour, the cover design reflected these changes.

On the occasion of the magazine's four year anniversary on November 11, 1971, Rolling Stone was further embracing its alignment with the mainstream press. In an editorial in the issue, Wenner affirms, "We have been called (by Time) The New York Times of the alternate culture ... and both our

\footnotetext{
92 Chambers, The Management of Small-Offset Print Department, 166.

93 Ibid., 169.

${ }^{94}$ Alix Nelson, "The Rolling Stone Reader." The New York Times Book Review, April 14, 1974.
} 
friends and critics have used the 'new Times magazine' metaphor to put us in our place. Such comparisons are not totally inaccurate: we're media ... an eye for unknown thousands of people to see their world through." ${ }^{15}$ Their popularity was apparent, as 1971 was Rolling Stone's most profitable year, bringing in profits of $\$ 400,000 .{ }^{96}$ Now that Rolling Stone had become recognized for its professionalism, it began to market itself like a mainstream publication. By June of 1971 the masthead moved from the right side of the cover to the centre and was visibly larger. Similar to the year previous, the vast majority of cover photographs were portraits from the shoulders up. However, one marked difference is that studio portraits were now making a regular appearance on the cover of Rolling Stone [FIG.44].

Most of these portraits were shot by Annie Leibovitz, who was hired on at Rolling Stone earlier in the year. Though her trademark stagecraft had not made its appearance yet, the idea of positioning an iconic or unique portrait of a famous personality

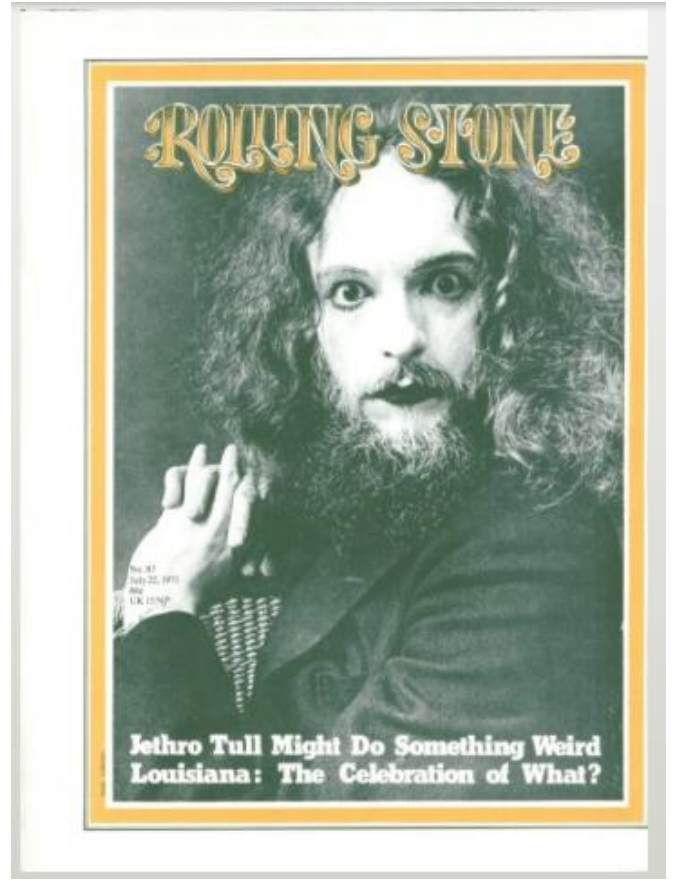

FIGURE 44: Annie Leibovitz, cover of Rolling Stone magazine (July 22, 1971).

as the main selling point of the magazine was beginning to take form. Leibovitz's portraits stayed true to the unpremeditated aesthetic of Wolman's cover photography, as photographs that had an element of spontaneity and immediacy were still favoured. However, in an interview with Stephen Meyers regarding her photographs for an American Express advertising campaign, Leibovitz discussed that as years went on Rolling Stone regrettably no longer used this aesthetic for their covers, as studies showed that more complex, conceptual cover photographs sold less magazines. ${ }^{97}$ The kind of immediacy that

\footnotetext{
95 Nelson, "The Rolling Stone Reader."

96 "Wenner Media, Inc. History."

97 Mark W. Rectanus, Culture Incorporated: Museums, Artists, and Corporate Sponsorships (Minnesota: University Of Minnesota Press, 2002), 104.
} 
Leibovitz laments was something that fellow photographer Linda McCartney's (née Eastman) photographs effectively portrayed.

Both of these photographers had a relationship with their subjects, whether through friendship or being embedded with them on tour, which helped to convey intimacy and personality. For instance, Jimi Hendrix often sought out McCartney for portraits as he believed that her photographs never looked forced. ${ }^{98}$ In her seemingly candid photograph of Eric Clapton for the cover of May 11, 1969 issue of Rolling Stone [FIG.45], her sitter appears at ease and in mid

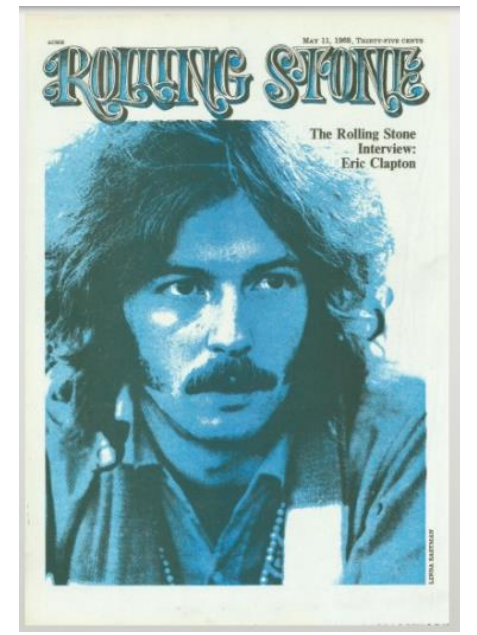

FIGURE 45: Linda Eastman, cover of Rolling Stone magazine (May 11, 1969).

thought. Therefore, though McCartney's photographs were naturally lit and out of studio, what her photographs shared a similar aesthetic to Leibovitz's-unguarded and unposed. As illustrated by Leibovitz's earlier quote, this style of photography was in vogue during the late 1960s, because it tapped in to the sensibilities of the time. Not surprisingly, Rolling Stone abandoned this aesthetic as it fell out of fashion.

\section{Conclusion}

Though this study accounts for only five years, in this short time span we see a clear motioning toward the professionalism of a mainstream publication. Through this evolution they adapted elements of both the mainstream and the underground to market themselves -in the process establishing their own distinct style of cover photography. In its early years Rolling Stone aligned itself with the ideals of the 1960s by publishing photographs that had an immediate quality and by integrating elements of psychedelic design. The changes tracked in this chapter indict that Rolling Stone was abandoning these design elements in order to market itself outside of the 1960s and distancing itself from the underground. However as it moved toward the mainstream, the aesthetic of the photographs produced

\footnotetext{
98 Harper's Bazaar Staff, “Linda McCartney Photographs,” Harper's Bazaar, March 22, 2011.
} 
on its covers remained. In the years that followed, this evolution becomes markedly clearer; beginning in 1973, issues were produced on a four-colour press and by 1980 the magazine became a gloss paper. More text was introduced on its cover, a larger masthead, splashy primary colours, and provocative celebrity portraits helped to market the magazine as cutting edge and relevant. During the 1960 s, this relevancy was dependent on staying in touch with the larger cultural and photographic trends. Specifically this meant abandoning the so-called canon of pre-visualized photographs and embracing the immediacy only the camera could reproduce-much like the amateur aesthetic. The philosophy driving proponents of this aesthetic were similar to those of the underground press, in that both groups wanted to visually distinguish themselves from a previous model. 


\section{A Comparison of Life and Rolling Stone: A Case Study of Woodstock and the Democratic National Convention of 1968}

"What does the magazine do better than any other medium?" he asks. "It does photography better. It does layouts better. It does long reads better. You can have a point of view. And if you do those things well, you'll have an audience that's loyal and steady — and the advertisers will follow." 99

-Jann Wenner

American author Gay Talese describes the development of New Journalism as leaving behind "the wire-service mentality-just get the facts and tell the story straight-well how could you do that and sell newspapers if people had already got a sense of it through television, even a more visual sense in less time." ${ }^{100}$ In his description of the struggles that journalism faced in the 1960s, he hints at the visual competition that television posed to magazines like Life. Just as writers needed to develop a new style to respond to this, so did photojournalism. What the rise of specialization in the illustrated press alludes to is a desire for diversity of opinion, more nuanced reporting, and an aesthetic that faithfully represented the ethos of the time, in both subject and aesthetic. Based on an analysis of both Life and Rolling Stone's coverage of two pivotal events in American history, The Woodstock Arts \& Music Fair and the events surrounding 1968 Democratic National Convention, people were no longer buying magazines based on the quality or amount of photography alone, but for the context in which these photographs appeared and the attitudes they expressed in their aesthetic.

\section{An Honest Fiction: News Photographs and Objectivity}

Mainstream magazines such as Life liked to give the appearance of journalistic professionalism, adhering to a strict code of neutrality. This should not be confused with objectivity, which Henry Luce was forthright in explaining his feelings about: "Show me a man who think's he's objective and I'll show you a man who's deceiving himself." ${ }^{101}$ The form of reality that Life supposedly depicted in their

99 David Lieberman, “Rolling Stone Founder Keeps Things Fun” in USA Today, June 11, 2007. http://www.jannswenner.com/Press/Rolling_Stone_Founder_Keeps_Things_Fun.aspx

100 Sumner, The Magazine Century: American Magazines Since 1900, 149.

101 Michael Schudson, Discovering the News: A Social History of American Newspapers (New York: Basic Books Inc., 1967), 149. 
photographic essays, "showed things in an unbiased, unmediated fashion; in other words showing things as they are, not what they felt like." ${ }^{102}$ However the literary, subjective style of New Journalism was beginning to gain popularity during this time, as it spoke to the idiosyncrasies and diversity of the era. Perhaps the most famous proponent of New Journalism was Hunter S. Thompson whose "Fear and Loathing" series for Rolling Stone made no attempt to provide "balanced" perspective. In a colourful reaction to Nixon's resignation Thompson remarked, "If there were any such thing as true justice in this world, his rancid carcass would be somewhere down around Easter Island right now, in the belly of a hammerhead shark." ${ }^{103}$ Professor of Journalism David E. Sumner describes New Journalism as "commonly [citing] fiction techniques including scene-by-scene storytelling, character development, dialogue, monologue, and detailed descriptions... described as 'new' at the time because it departed from the traditional inverted pyramid, 'Five-W' style of reporting." ${ }^{104}$ Many of the more specialized magazines of the 1960s were quick to adopt New Journalism; along with Rolling Stone, Esquire, The Advocate and New York all published the long form, subjective style of journalism.

As Rick Slater explains in his thesis titled, "Changing Images of the Democratic Party: An Analysis of the Aesthetic and Philosophical Underpinnings of Life's Photo-Essay 'Happy days in Miami'”, the influence of New Journalism on photography could be characterized into four categories: scene-byscene reconstruction; closeness between photographer and subject; overt stylization using unusual angles, distortion, or cropping decisions that alter the photographs appearance; and reliance upon status details to reveal a subject. ${ }^{105}$ Sumner goes on to describe the four historical factors that allowed New Journalism to develop: 1) the historical events of the 1960s, especially the Vietnam war, the civil rights movement, the women's movement, and the hippie-drug counterculture-all of which provided ample subject matter to write about; b) a group of innovative, risk-taking editors; c) a group of creative,

\footnotetext{
102 Slater, "Changing Images of the Democratic Party," 2.

103 Hunter S. Thompson, "Fear and Loathing: The Scum Also Rises," Rolling Stone, 10 October 1974, 28.

${ }^{104}$ Sumner, The Magazine Century: American Magazines Since 1900, 140.

105 Slater, "Changing Images of the Democratic Party," 12-15.
} 
risk-taking writers; d) the rise of television and its influence on the competitive media marketplace. ${ }^{106}$ Clay Felker, the editor of New York from 1962 to 1974, discusses the start of New Journalism: "What New Journalism did was recognize that there was new competition for print... television. That brought news to people quicker than a daily newspaper or a national newsmagazine. And so what you had to do was give another interpretation. You had to present the news in a more emotional, interpretive conceptual context."107

In some ways the impressionistic accounts of New Journalism responded to the fracturing of a solid American middle class, giving primacy to the individual response rather than trying to speak to the collective whole. Ultimately journalism was moving away from the standard neutral accounts of the mainstream, and providing an alternative that spoke to the specialization of the consumer magazine industry as well as the diversification of American society as a whole.

A Photographic Aesthetic to Compliment New Journalism

Beginning with a comparison of the Life photo essay titled, "The Big Woodstock Rock Trip", with photographs by Bill Eppridge and the Rolling Stone photo essay titled "The Woodstock Festival", with photographs by Baron Wolman, there is a marked difference in how photographs were used in the respective publications. A gathering of more than 450,000 attendees, the Woodstock took place at the end of the 1960 s and is often seen as a culmination of the values that sustained the movement: psychedelic drug use, communal living, direct action, and rock music. As previously mentioned, Life magazine tended to depict youth culture with a sense of otherness-using photographs as a vehicle to address these topics, without devoting much copy to it. Here Woodstock is described as, "a mob", "scary" and having "the look of a massive, poorly supervised, three-day summer camp for city kids... [where] disaster was always around the corner", and figures are photographed from a safe distance. The

\footnotetext{
106 Ibid., 148-149.

107 Sumner, The Magazine Century: American Magazines Since 1900, 149.
} 
text that accompanies the essay is scarce, highlighting quotes that portray the festival as unorganized and unsafe with little mention of the concert. The visual narrative portrays progressively more disorganization, leading to the dystopic full spread photograph of the ravaged alfalfa fields. In contrast to Life, Rolling Stone describes Woodstock as

"a turning point in the consciousness of a generation," where photographs showcase the concert goers and musicians up close. Their take is more lighthearted, emphasizing the excitement and scale of the festival. In a similar way The Washington Post's ${ }^{108}$ coverage

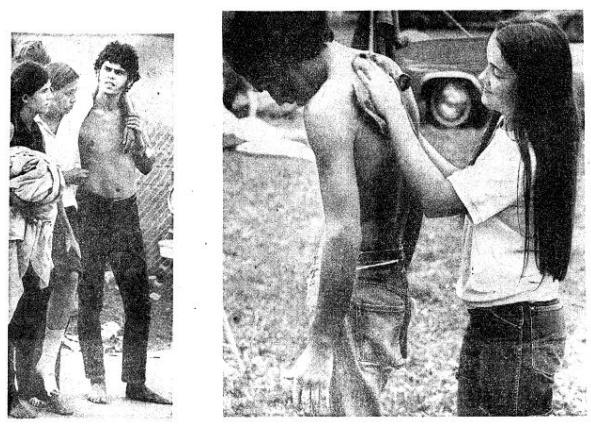

FIGURE 46: Detail from "Impressions After Woodstock," The Washington Post, August 24, 1969.

of Woodstock highlights the goodwill and cooperative nature of the festival-both in its text and photographs. In two of the three photographs that accompany the article [FIG.46] concert goers are

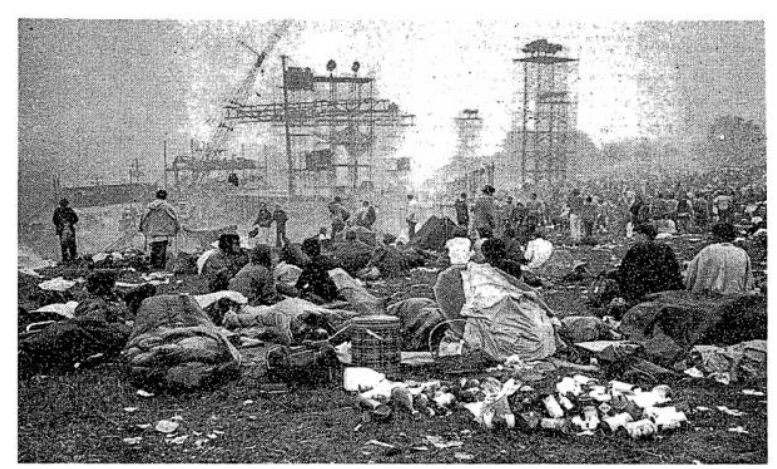

FIGURE 47: Detail from “"“300,000 at Folk-Rock Fair Camp Out in a Sea of Mud," The New York Times, August 17,1969. shown helping one another: with one attendee

helping another one after an accident, and an image of a man being dried off by a friend.

Though these visuals alone depict single incidents, the overall conclusion of the article is that Woodstock brought together two groups of people (the counterculture and the

establishment), and that despite differences, they were respectful of one another. Conversely, The New York Times ${ }^{109}$ coverage of the festival tell a similar story to Life. There are five photographs in the article

\footnotetext{
${ }^{108}$ B.J Phillips, "Impressions After Woodstock," The Washington Post, August 24, 1969.

${ }^{109}$ Other New York Times articles on Woodstock include: "346 Policemen Quit Music Festival" in the August 15, 1969 edition, "200,000 Thronging to Rock Festival Jam Roads Upstate" in the August 16, 1969 edition, and "Nightmare in the Catskills" in the August 18, 1969 edition.
} 
“300,000 at Folk-Rock Fair Camp Out in a Sea of Mud" [FIG.47] ${ }^{110}$, each one highlighting a negative aspect of the festival. For instance, one photograph of an audience facing the stage has a caption that reads "GARBAGE piled up everywhere, causing a health hazard," highlighting the small pile of garbage in the foreground. Regardless of slant, in both The New York Times and The Washington Post, photographs have a sharp focus, a tight crop and portray a clear narrative. Life uses photographs in a similar way in its coverage of the Woodstock festival, where the link between text and photographs is clear. While Rolling Stone provides a more impressionistic account deviating from the traditional methods of using photographs to report the news. In both Life's and Rolling Stone's account of the festival the weather conditions, and discomfort are discussed-in both cases visually and within the text. However, like The New York Times' coverage, this seems to be the focus of Life's account. The rain and scale of the concert are no doubt important aspects of the story, but by focusing only on these aspects they downplay the significance of the event, which brought together dozens of influential musicians and an overwhelming showcase of solidarity among attendees.

Perhaps the most striking dissimilarities between the two photographic representations are the differences in size and in colour. In the ten pages of coverage that Life magazine devotes to the festival, photographs take up $87 \%$, with copy taking up only $3 \%$ (the remaining $10 \%$ is white, negative space) ${ }^{111}$, mainly providing captions for the photographs. Three of the photographs used in "The Big Woodstock Rock Trip" are full bleed, taking up the entire page or spread. While in Rolling Stones eleven pages of coverage, the black and white photographs and copy make up a ratio of around 60:40, with only one page featuring solely photographs. As a purveying of rock journalism, The Woodstock Arts \& Music Fair was an important news event for Rolling Stone and unpacking the events of the weekend fell under their mandate of providing coverage for "the things and attitudes that the music embraces." ${ }^{112}$ Therefore the

\footnotetext{
${ }^{110}$ Barnard L. Collier, "300,000 at Folk-Rock Fair Camp Out in a Sea of Mud, " The New York Times, August 17, 1969. 111 This calculation is based on photographs taking up $6583 \mathrm{~cm}_{2}$, and text taking up $252 \mathrm{~cm}_{2}$ of the $7537 \mathrm{~cm} 2$ of page area.

112 Jann Wenner, "Random Notes," in Rolling Stone, November 7, 1967, 3.
} 
story required a strong accompanying editorial treatment as well as pictorial elements. As illustrated by Life's minimal editorial treatment, someone interested in the real atmosphere of the festival would have to turn to an alternative publication like Rolling Stone. Baron Wolman explains his experience photographing the festival: "I was on a three-day high photographing Woodstock. Because I had photographed most of the performers by then, I concentrated on the "Woodstock Experience," what it meant to have been there, to have attended the event."113 The typical Rolling Stone reader would have attended the

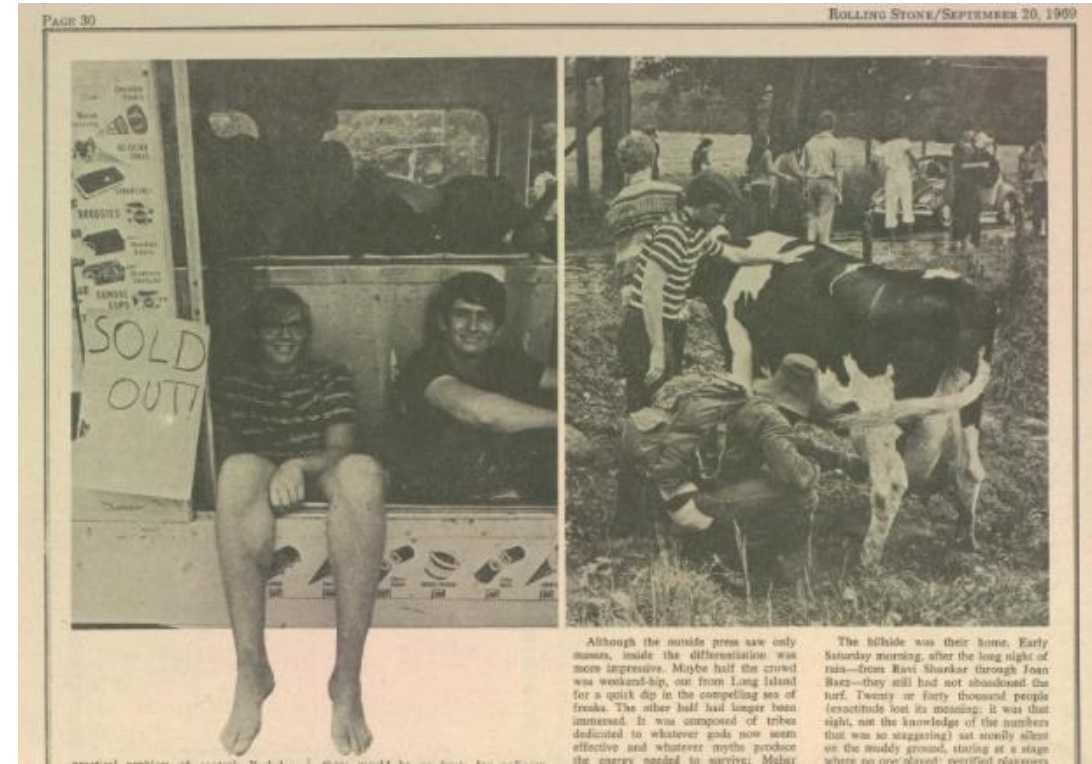

FIGURE 48: Unknown photographer, detail of "The Woodstock Festival" in Rolling Stone magazine (September 20, 1969), 30.

Woodstock festival, and so the photographs published have the look of photographs taken for a personal album, creating proximity with the readership [FIG.48]. The vantage point that many of the Rolling Stone photographs are taken is from the perspective of someone who belongs at the festival, in six photographs the concertgoers are aware of or interact with the camera-at odds with kind of photography seen in Life. Though some of the content of the photographs in both publications is similar (the food tents, the bathers) unlike Life's coverage, the photographs laid out in "The Woodstock Festival" do not illustrate a narrative. Rather, Rolling Stone's coverage begins with a photograph that features in its foreground cows lying dormant in a field while a camp of tents and concertgoers in the background, and ends with two young men milking a cow. The editorial content does the job of laying out the events, and so the photographs are servicing this text. In the case of Life magazine's coverage,

${ }^{113}$ Baron Wolman, interview by Rachel Lobo, Toronto, ON, April 28, 2014. 
the text services the photographs. Because almost all of the text in Life's account is captions, the only function the text plays is explaining the visual content. Therefore, the photographs do most of the speaking, and have a clear visual focusfaithful to the way the scene appeared. It makes sense than that of the seventeen photographs featured in the essay, only one is in black and

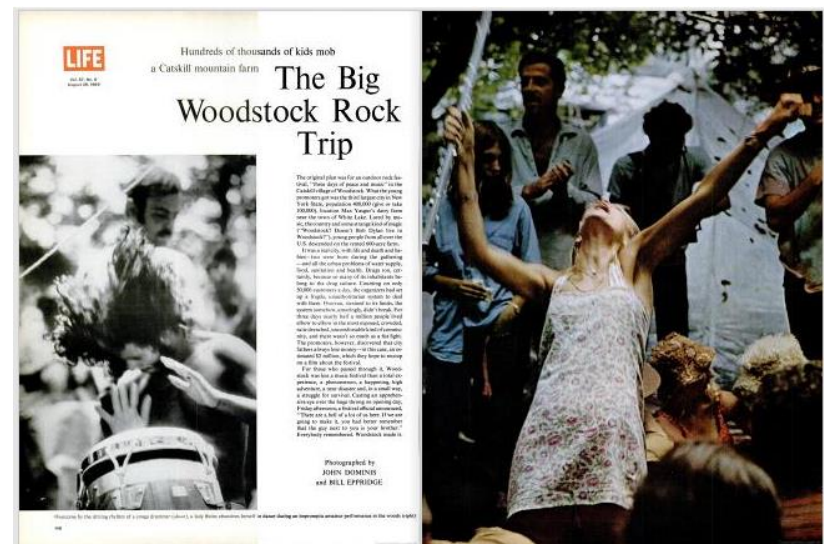

FIGURE 49: Bill Eppridge, "The Big Woodstock Rock Trip" from Life (August 29, 1969), 14-15.

white. The rest showcase the most spectacular aspects of the festival, the vivid colours typical of psychedelic fashion, the plush greenery of the Bethel forests, and the muddy, dankness of the overcast, rain drenched camp.

In analyzing the photographs used in Life's coverage we see the clear progression of a narrative, with each spread clearly articulating a specific sentiment. Typical of Life, each photograph adheres to the composition of a good press photograph, with unique angles, symmetry, clear focus, and leading lines. To illustrate, the first spread in "The Big Woodstock Rock Trip" pairs two candid photographs that illustrate dynamism, and demand the reader's attention. The black and white photograph on the left shows an impassioned drummer, his long hair thrashing above his head. On the opposite page the focus of the photograph is a slender, blonde-haired flutist, her head similarly flung back, arms in the air, as one hand grips her flute the other is clenched in a fist as she dances [FIG. 49]. Together, the photographs in this spread direct the reader's attention to the edge of each page, formally creating a visually pleasing v-shape. The next spread features a dominant, almost full bleed photograph that illustrates the scale of concert-a sea of bodies leading to the scaffolding of the stage in the distance [FIG. 50]. Photographed using a wide angle lens, the positioning of the crowd creates a diagonal, effectively creating perspective. Below this are six smaller photographs that each feature one concert- 
goer, in all but one case the subject seems

unaware of the camera. From a design

perspective these pairings were a

deliberate attempt to demonstrate the

individuals and the mass, or in newspaper

terminology "close-up and context." ${ }^{\text {"114 }}$ The

following spread demonstrates from a

keyhole perspective the logistics of the

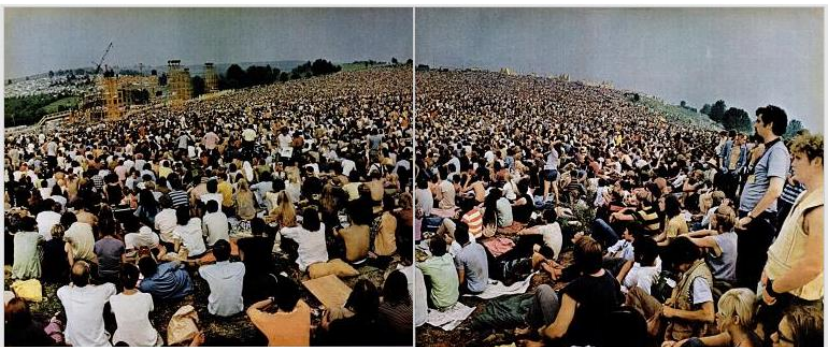

'It was scary. God, I had never seen so many people'

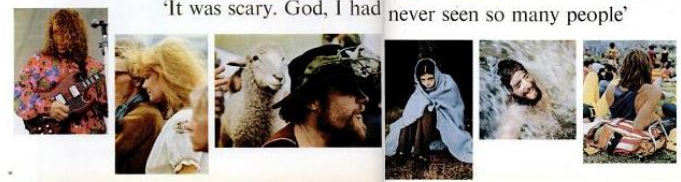

FIGURE 50: Bill Eppridge "The Big Woodstock Rock Trip" from Life (August 29, 1969), 16-17.

festival, establishing how the attendees bathed, ate, and slept [FIG. 51]. On the right side a full bleed photograph, framed by the foliage of the forest, features a group of seemingly nude concertgoers bathing. The opposing page has three photographs, each with a clear focus: the first image of the soles of two pairs of feet in a hammock; the second shows two women using a water tap, the image bisected by the pipe; the third photograph shows six people assembled in a line preparing food, the arm of one subject mimicking the diagonal of the counter. Sharply opposing the scenes of cooperation, and demonstrating the nadir of the event, in the last spread three photographs illustrate the

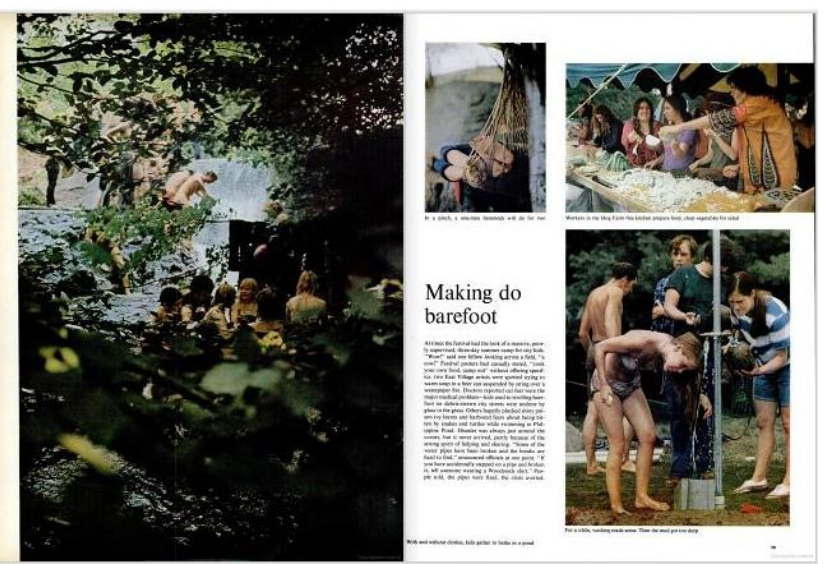

FIGURE 51: Bill Eppridge "The Big Woodstock Rock Trip" from Life (August 29, 1969), 18-19.

weather-torn and muddy atmosphere, with

sullen looking concertgoers taking shelter [FIG.52]. All three photographs feature a prominent subject holds their fingers crossed. Taken from an impactful viewpoint, the last spread features the ravaged alfalfa fields, muddy and full of debris, as dozens of figures roam the wreckage [FIG.53]. Reading the

${ }^{114}$ Daryl R. Moen, Newspaper Layout and Design (Ames: Iowa State University Press, 1984), 83. 
photographs from start to finish

demonstrates the clear progression of

events, adhering to Life's journalistic

policy of clear reportage and

adherence to the tenets of classic

photojournalism.

In a decisively different

account of the festival, Rolling Stones

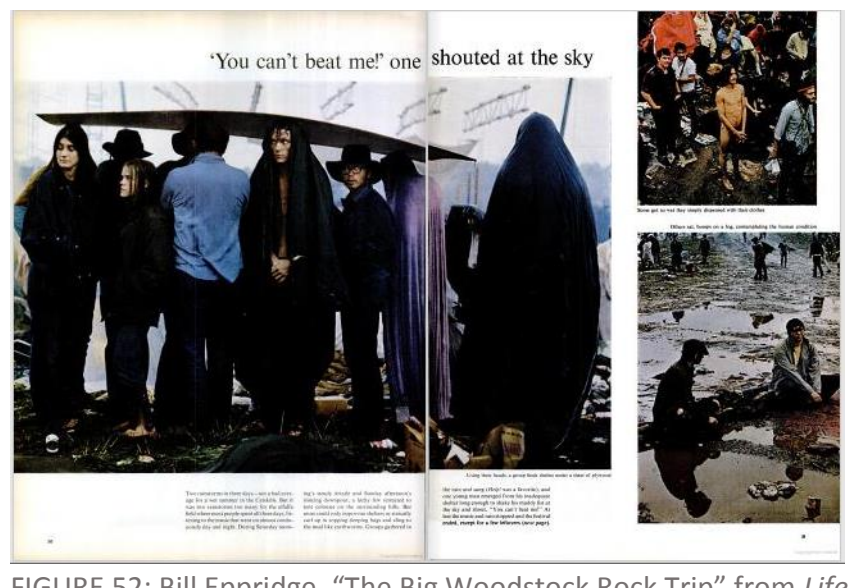

FIGURE 52: Bill Eppridge, "The Big Woodstock Rock Trip" from Life (August 29, 1969), 20-21.

coverage is much more nuanced than the standard chronology presented by Life. Though Greil Marcus' editorial provides a day to day account guided by the use of subheadings, woven in is incisive analysis, satire and even a few well-placed Biblical comparisons. The first page of "The Woodstock Festival" features the aforementioned half-paged photograph of cows laying in a field, likely displaced by the hundreds of thousands of campers that appear in the photograph's background. The four, half-page columns of copy that accompany Wolman's photograph, describe the media's reaction to the festival, and its wider cultural significance. The photograph mainly illustrates that the festival took place on an active dairy farm, but is not spoken to directly in the text that accompanies it. This is common throughout the story, where the text makes scant allusion to the information in the photographs. For instance, eighteen pages later, the third spread of the article features only one, rectangular photograph that

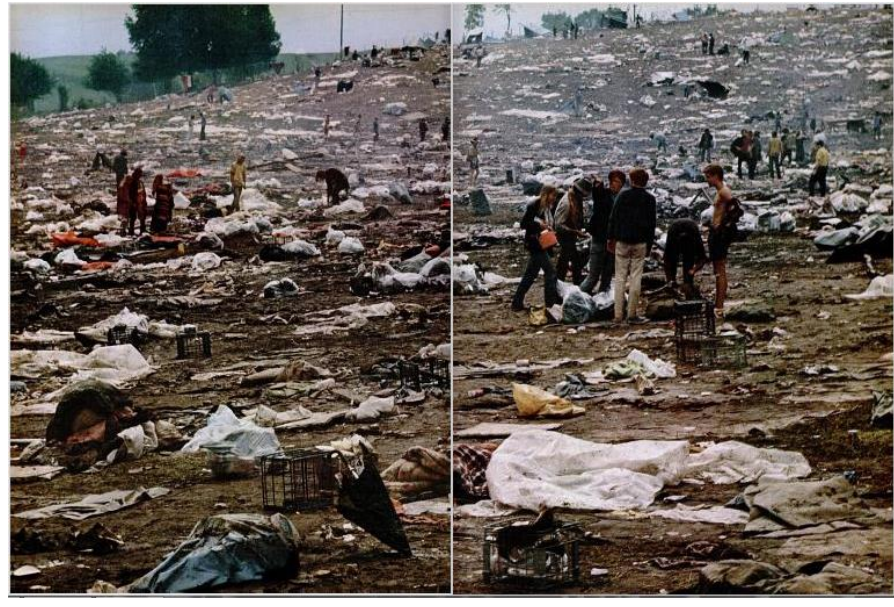

FIGURE 53: Bill Eppridge "The Big Woodstock Rock Trip" from Life (August 29, 1969), 21-22.

takes up the entire first fifth of the page (the facing page is entirely dedicated to an advertisement). An 
overall dimly lit scene, it features a lone subject walking along a row of portable toilets [FIG.54] -at most alluding to the "overflowing toilets" mentioned in below copy. A more obvious sign that the text and photographs were not laid out to directly communicate with one another is the lack of photographs of the performers. As Wolman mentioned, as the sole staff photographer at Rolling Stone he had photographed most of the Woodstock performers for earlier assignments. Accordingly a candid

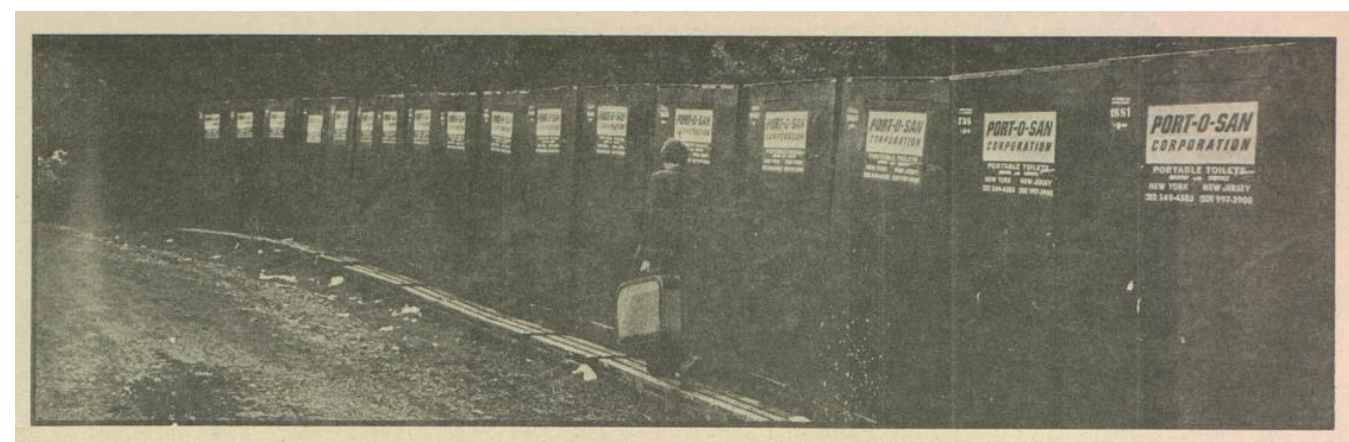

FIGURE 54: Baron Wolman, detail of "The Woodstock Festival" in Rolling Stone (September 20, 1969$), 18$.

photograph of Grace Slick of Jefferson Airplane represents the only representation of a performer in the entire story, though the text does make mention of several performers. Slick appears on the fourth spread with four other photographs-making the spread the most populated with photographs. Not surprisingly though in the copy that flanks Slick's portrait is there mention of multiple performers, there is no mention of Jefferson Airplane. Though there is less association between text and photographs, this is not to say that the design choices used to layout the photographs was precarious. Throughout the article there appear deliberate choices made to create a visually pleasing aesthetic. Typical of their use of photographs at this time, in three instances in "The Woodstock Festival"

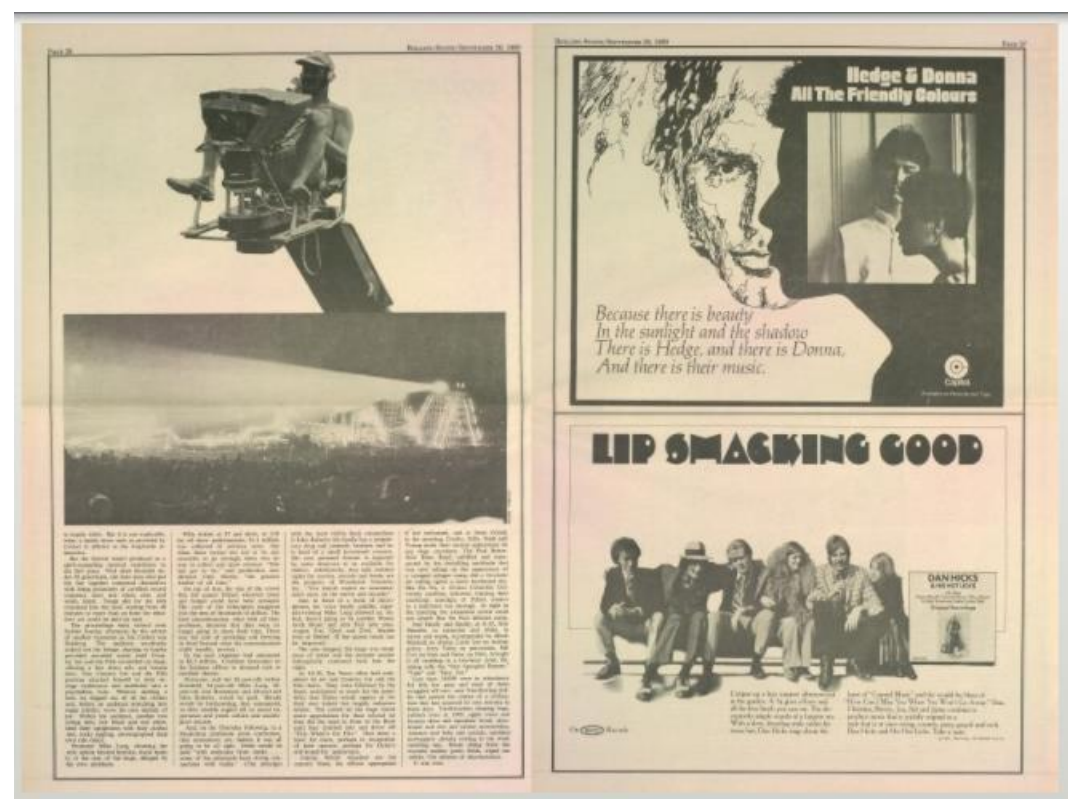

FIGURE 55: Baron Wolman, "The Woodstock Festival" in Rolling Stone (September 20, 1969), 26-27. 
the editors decided to single out an aspect of the image and cut it to hang outside of the photograph's border. In traditional newspaper layouts editors are cautioned against using silhouettes, as they omit informational content in favour of artistry. ${ }^{115}$ This first appears in the articles second spread where the silhouette of a smiling young man's arms hang outside the border of the photograph in order to frame the title of the story. Similarly, an image of a camera operator sitting on an elevated chair at the end of crane, silhouetted in order that the crane juts out from the photograph placed below [FIG. 55]. The diagonal here mimics a similar angle created by a shape used in an advertisement for Hedge \& Donna on the opposite page. Perhaps in an effort to imitate the first use of this technique, in the last spread the legs of a young man sitting in an ice cream truck hang out from the border of the photograph, his toes skimming the copy below. The use of silhouettes here drives home the idea that Rolling Stone was not looking to recreate a chronology of events by providing demonstrative or informational photographs, but rather to layout photographs so that they contribute to an overall "laid-back" or loosened aesthetic. Another clear design technique

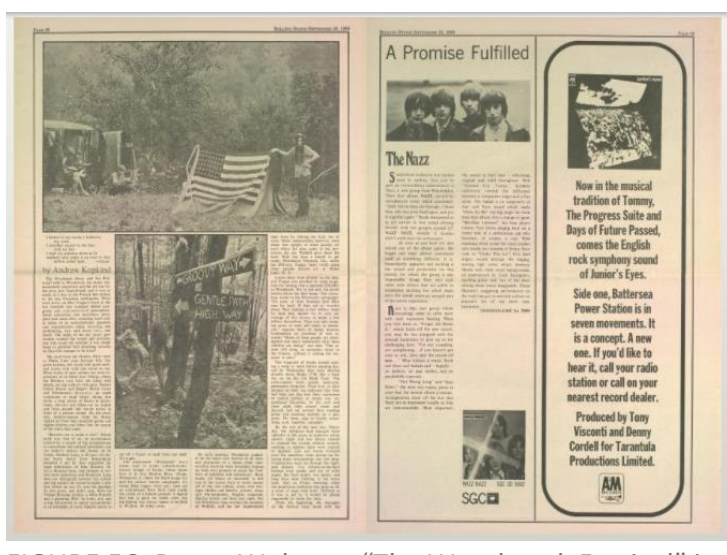

FIGURE 56: Baron Wolman, "The Woodstock Festival" in Rolling Stone (September 20, 1969), 28-29.

is the layout of photographs to form a "T-shape"; in four spreads a larger, horizontal photograph sits atop of a narrow, vertical photograph [FIG.56]. This "T-shape" serves a similar function as a "U-shaped" format; "many newspapers use the U-shaped format to relieve the monotomy of the formal balance, even though the reader must make a long journey to last column of type."116 Normally this picture pairing principle is used to demonstrate detail and environment-with a clear hierarchy of dominantsubordinate. ${ }^{117}$ In Rolling Stones use of this convention there is no clear relationship between the

\footnotetext{
${ }^{115}$ Moen, Newspaper Layout and Design, 82.

116 Ibid., 72.

117 Ibid., 85.
} 
photographs-it is used solely as an eye-pleasing design feature. Breaking further with traditional layout principles, on pages where there are multiple photographs the size of the interior margins is not consistent. Similar to the design choices made elsewhere in "The Woodstock Festival", this illustrates that adhering strictly to traditional convention was not necessary to creating a successful editorial.

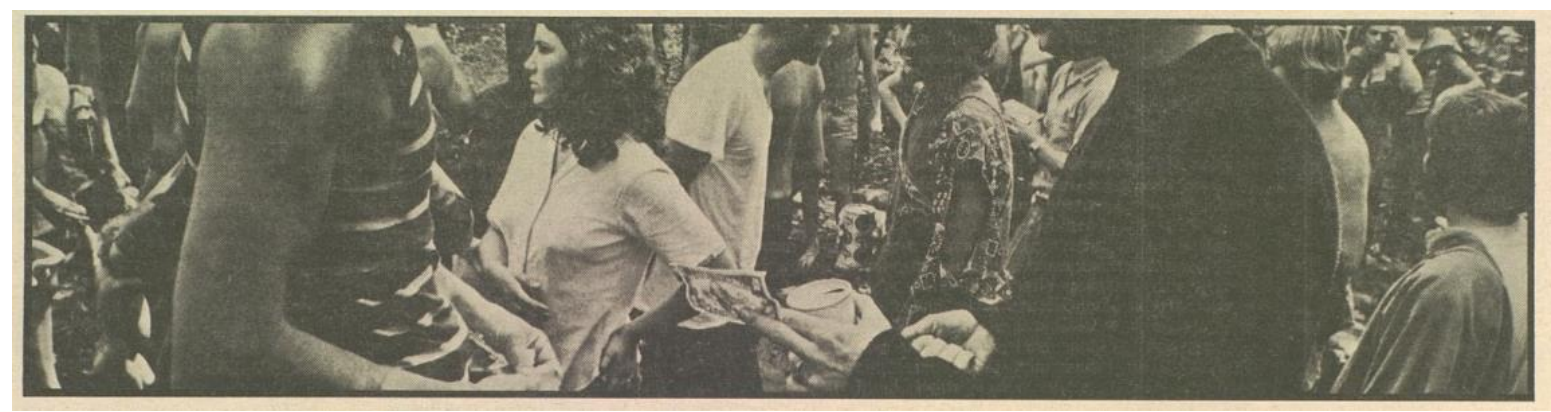

FIGURE 57: Baron Wolman, detail of "The Woodstock Festival" in Rolling Stone (September 20, 1969), 23.

A similar attitude was adopted when it came to the kinds of photographs chosen for print.

Moving away from the craft elements of photojournalism,

Wolman's photographs are markedly more casual with a

snapshot aesthetic. If we take for instance the photograph in the

fifth spread, of what is likely a drug transaction [FIG. 57], the

heads of the subjects are bisected by the frame, and the focus of

the photograph is unclear. Similarly in the first spread, a

photograph of a blissful man, arms spread in cheer, perched atop

of a trailer in a line of traffic is oddly framed-disobeying the rule

of three, with the entire right half of the photograph negative

space [FIG. 58]. Overall, the choice of photographs used in "The

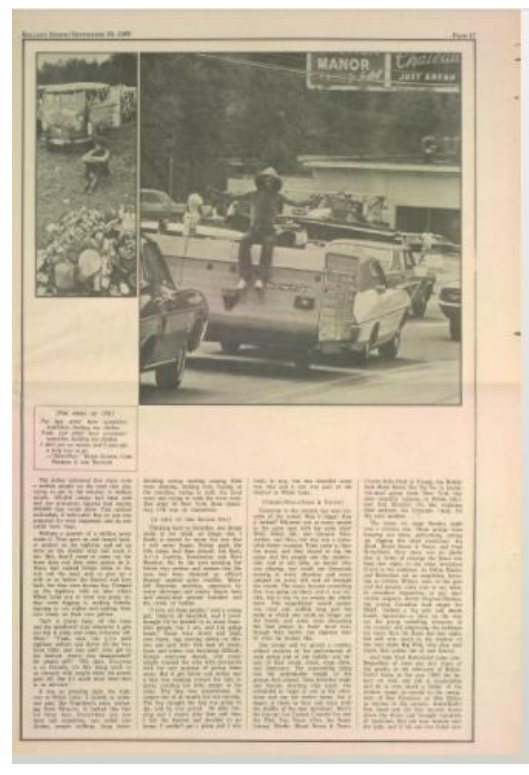

FIGURE 58: Baron Wolman, "The Woodstock Festival" in Rolling Stone (September 20, 1969), 17.

Woodstock Festival" are similar to the aesthetic of the underground press where photographs display immediacy with a casual aesthetic, and were displayed in more conceptual layout. Adding to this effect is the lo-fi quality of the uncoated paper that the photographs are printed on. As mentioned earlier this aesthetic was at odds with Life magazine who published only well composed photographs that strictly 
adhered to the aesthetic of classic photojournalism. Rolling Stone engaged in a loosening of these values in order to display their idea of what was real, or what helped the audience to "feel it". The overwhelming feeling of these photographs presents youthful excitement, an atmosphere that at times was both chaotic and idyllic and that ultimately fostered

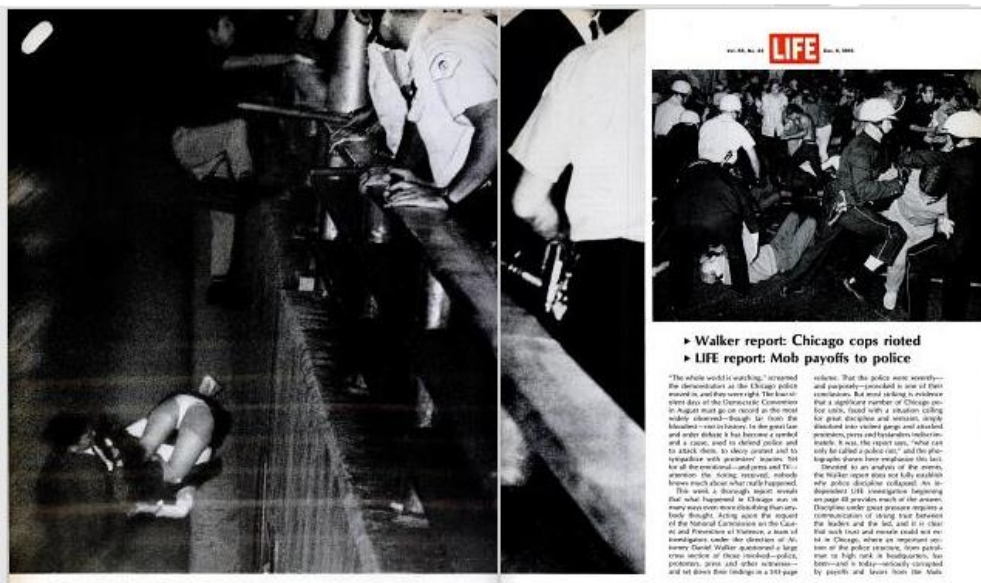

Corruption behind the swinging clubs experimentation and fun.

\section{Picturing Radical Politics: Representations of the Police Riots at the DNC of 1968}

As outlined earlier, Life liked to give the appearance of journalistic professionalism by providing a multivalent interpretation of events. So in Life's six pages of coverage on the Democratic National Convention the editors diplomatically reprint a timeline of events from the Walker Report, a report commissioned by The National Commission on the Causes and Prevention of Violence to investigate the police riots. Despite the title of the story, in "The Chicago Police Riot"118 the photographs illustrate this timeline, an attempt to highlight the violence of both sides of the conflict-with captions reflecting the violence of the police, and demonstrators provoking officers. The photographs are printed with a clear focus, where the focal point of the photograph is easily distinguishable. In Rolling Stone's coverage titled "Chicago"119, the sequencing of photographs is not chronological. Rather like the text they illustrate the wider cultural implications of the trial. Mugshots, candid portraits, and illustrations are laid out throughout the 22 pages of heavy text. Occupying the subjective, literary style of New Journalism,

118 "The Chicago Police Riot," in Life, December 6, 1968

119 "Chicago," in Rolling Stone, April 2, 1970. 
Rolling Stone espouses that "we are approaching a situation that in terms of psychology is much like war." ${ }^{120}$ It should be noted that though Rolling Stone devotes almost a third of its issue to the trial in 1970, immediately after the convention was held in 1968 they devoted only half a page to analysis. In 1968 this omission could be Wenner's attempt to not engage in "sandbox politics". However an article titled "The Sound of Marching, Charging Feet" in the April 5, 1969 issue, the magazine takes a different tone: "Like it or not, we have reached a point in the social, cultural, intellectual and artistic history of the Unites States where we are all going to be effected by politics."121 This issue, which was titled "American Revolution 1969", marks the beginning of more political coverage in Rolling Stone. Despite the two year gap in events, a comparison of Life's coverage of the convention and Rolling Stone's coverage of the trial, is used to analyze how a news story with the same players was represented in each magazine. Conversely, though Life made the police riots its cover story in 1970 when the trial of the Chicago Eight had ended after months of deliberation, Life magazine dedicated the last two pages of its February 20, 1970 issue to a quiz requiring the reader to attribute the twenty-two most outlandish questions asked at the trial to twenty-two of the trial's participants. Though the trial lasted six months and collected over 20,000 pages of transcript, curiously Life magazine's coverage was brief and scattered. For both publications, the subject matter was contentious.

In Life's December 6, 1968 issue, the police riots at the Democratic National Convention of 1968 is the cover story. In "The Chicago Police Riot," the photographs are supplied by the Chicago Sun-Times and UPI, and fall under what Mich would categorize as "Illustration for Text." Mich explains that, "in the study of the picture story technique it must be noted that there is a difference between using pictures as illustrations and using them to tell a story or develop a thesis... pictures used as illustrations [can] add to a story's impact on the reader"122 Therefore, because the photographs selected illustrate the Walker

\footnotetext{
120 Ibid., 38.

121 Michael Rossman, "The Sound of Marching, Charging Feet," Rolling Stone, April 5, 1969.

122 Daniel D.Mich and Edwin Eberman. The Technique of the Picture Story: A Practical Guide to the Production of Visual Articles (New York: McGraw-Hill Book Co., 1945), 15.
} 
Report, "The Chicago Police Riot" is not a picture story, rather as Mich points out they are used to visually elucidate the editorial content. Striking a careful balance of photographs of protesters provoking and police officers swinging club, the editors of Life tap into the polarizing effect that the riots caused in public discourse. Likely because the riots occurred after nightfall, the photographs are printed in black and white, heightening the drama. The menacing faces of the Chicago police force, and bloodied protesters are reminiscent of the civil rights demonstrations in Birmingham, Alabama-conveying a clear sense of good and evil. Art Director at the time Bernard Quint, most famously known for his collaborations with W. Eugene Smith in "The Spanish Village" and "Pittsburgh", was notorious for printing photographs dark in order to create impactful layouts. In each of the ten photographs laid out there is a real sense of action and dynamism-amplifying the violence that unfolded that night. Take for example the first photograph in the first spread, where a woman lays

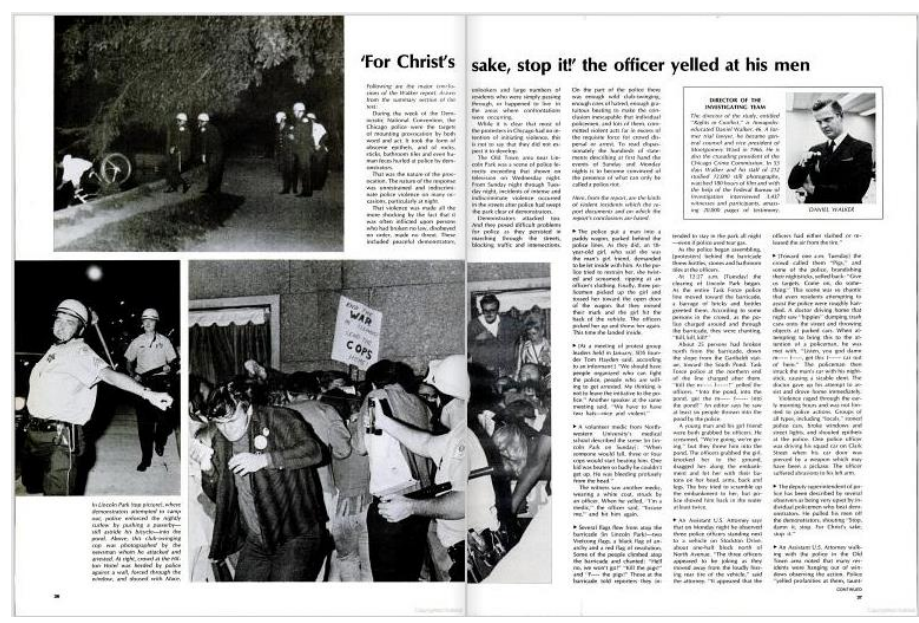

FIGURE 60: "The Chicago Police Riot" in Life (December 6, 1968), 36-37. contorted and indisposed on the sidewalk [FIG. 59], as a line of police officers look down at her from a railing, all while a man scales the wall leading up. Turning the page, photographs showcases one photograph of a police officer with his baton in mid-swing [FIG.60], and an officer aiming the stream of his pepper spray at a flinching demonstrator. Though perhaps limited by their lack of colour, all but one of these photographs is clearly produced, with obvious focus, and details finely rendered. As photographs were supplied by the wire agencies, "The Chicago Police Riot" might be classified as a compiled story, where photographs were selected from a variety of sources to dramatically support the 
central theme of the text. ${ }^{123}$ In this case the editors at Life felt that an editorial was not necessary, as they reprinted the analysis provided by the official party line-the Walker Report which takes up only $22 \%$ of the text. The large, rectangular, action-packed photographs take up $65 \%{ }^{124}$ of the three spreads, an attempt to build interest before the next article, an investigative report on the ties between the Chicago police and the mob.

Rolling Stone had previously stayed away from politics, believing as Wenner explained that there was a "bankruptcy of both sides... there must be a way out, and rock ' $n$ ' roll is it." ${ }^{125}$ In "Chicago: The Trial of the New Culture" 11 spreads of coverage, almost completely uninterrupted by advertisements, freelancer Gene Marine indicts the Chicago justice system for the convictions laid down on the Chicago Seven protestors and links it to the larger cultural war going on in America. To be precise, in "Chicago" text takes up $40 \%$ of the entire article, while photographs take up only $24 \%{ }^{126}$. Marine's editorial takes up far more space than photograph, and supplies a chronological account and analysis of the court proceedings. Accordingly, the first three pages in the story use photographs to illustrate the major players of the trial, with candid and posed portraits and mugshots identifying the defense, the defendants, the prosecution and Chicago's Mayor Daley [FIG. 61].

\footnotetext{
123 Ibid., 109.

124 This calculation is based on photographs taking up $2954 \mathrm{~cm}_{2}$, and text taking up $1005 \mathrm{~cm}_{2}$ of the $4522 \mathrm{~cm}_{2}$ of page area. The remaining $13 \%$ is white, negative space.

125 Peck, Uncovering the Sixties: The Life and Times of the Underground, 107.

126 This calculation is based on photographs taking up $5440 \mathrm{~cm}_{2}$, and text taking up $9105 \mathrm{~cm}_{2}$ of the $22,543 \mathrm{~cm}$ of page area. The remaining $36 \%$ is white, negative space.
} 
In the same informational fashion, a photograph of Chicago with a series of numbers dispersed over it and an accompanying legend illustrates "Where the Action Was" communicating quickly and effectively the geography of the event. The role of photographs in these early spreads is to clearly layout or set the stage for the reader visually, in order that the story laid out over the next seven spreads of text is easy to follow. From here only three photographs taken at the convention in 1968 are printed. Supplied by UPI and Photon West, these photographs do not clearly represent the violence of the police or the provocation of the demonstrators to the same effect as the photographs published in Life's coverage two years earlier. Here the photographs only show the police presence, the sea of police helmets, a dump truck spraying water (the caption reveals that the spray was aimed at protestors), and a young officer with his sniper rifle aimed at the camera [FIG.62]. The emphasis of these photographs is on the scene, or the atmosphere in Chicago; of overwhelming force and aggression. Unlike Life's illustrations of the aggression of both sides, Rolling Stone makes no attempt at neutrality, mimicking Marine's account. As historian Howard Zinn asserts, the Walker Report "gives only the mildest picture of that series of bloody beatings and forays by police... it must be remembered that Walker Study Team was headed by a prominent businessman and lawyer, conservative in background, Daniel Walker."127 Perhaps because they were outsourced, these three photographs clearly adhere to the

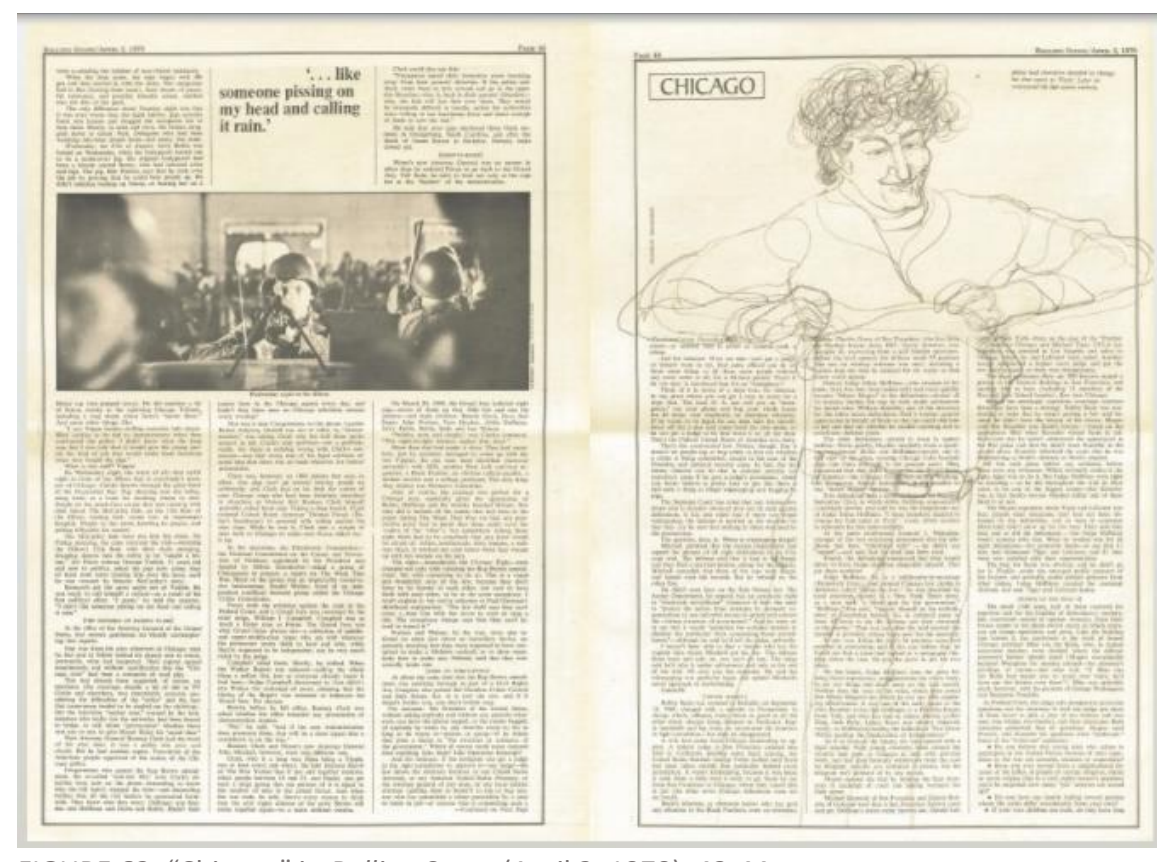

FIGURE 62: “Chicago" in Rolling Stone (April 2, 1970), 43-44.

127 Zinn, Postwar America: 1945-1971, 177. 
craft elements of photojournalism, mainly in their clear focus and interesting angles. This style of photographic representation runs steady throughout "Chicago" regardless of photographic producer. This and the repetitive placement of photographs on the upper half of each page are the only consistencies in the layout of this story. Unlike "The Woodstock Festival", there is a clear relationship between photographs and text that share the same page. However like "The Woodstock Festival", in their use of silhouettes, mortising, and the integration of illustrations by Frank McMahon, in "Chicago" there still exists an element of "bucking the trend" when it came to traditional magazine layout. The photographs used in "Chicago" are traditional press photographs, indicating perhaps that two years after "The Woodstock Festival" Rolling Stone was gesturing toward the style of photography used in general interest magazines. Or that as an important news story covered by established journalist Marine, "Chicago" deserved more professional looking treatment. In this way, the photographs again service the text-an incisive, news story on the cultural war.

Like Griel Marcus' coverage of Woodstock, Marine's account of the Chicago Seven trial takes on the form of New Journalism: long-form, having the posture of subjectivity and literary in style. Made clear by the higher ratio of text to photographs than Life, at Rolling Stone photographs were therefore chosen for how they serviced editorials. In a similar way, in most cases photographs were not chosen for their informational value, but for their ability to service the trends in writing of the time. In the same way, Rolling Stone's layout warmly embraced the influences of 1960 s design, a nod to the 1920 s and Art Nouveau. A clear example that points to the allegiance to journalistic and design trends is the use of silhouettes, whereby visual information is omitted in favour of a more conceptual or natural forms. As made clear earlier, what was important to Rolling Stone was propagating their allegiance to the trends of the time, and appearing as an alternative. In Rolling Stone's estimation, Life and its penchant for "straight journalism" did not align with the cultural developments of the time. In order to distance themselves from the traditional sensibilities of the mainstream they needed to signal to their readership 
that they were an alternative. The product of this signaling then is a deviation from the standard illustrated editorial, toward more incisive analysis and photographs that served this narrative-namely because photographs were no longer the centerpiece. During this period, this meant having smaller, more conceptual photographs with an amateur aesthetic than the traditional press. If we look at the photographs published in the underground press' account of the convention, this is clearly demonstrated. For instance, in the San Francisco Express Times' coverage, photographs are blurry, making it almost impossible to identify the point of interest. Though the underground press in many ways was bound to have less-professionalism by virtue of their lack of funding, Rolling Stone with its pick of "talented, working professionals"128, made the choice to coopt the looseness of the counterculture while giving it a more professional spin. Their supply of photographs for "Chicago" is indicative of this, as they used more traditional suppliers like UPI as well as photographer David Fenton of the underground Liberation News Service.

What a comparison of Life and Rolling Stone makes clear is that photography in each publication responded to their cultural sensibilities of the time. Life having little understanding of the makeup of their audience, published large, colour photographs that reconstructed events with clarity, with text used only to service these photographs. Their demise was in part due to this critical misunderstandingnamely their inability to react to the change in their readership's visual appetite based on the widespread ownership of a television, and on their inability to respond to their appetite for diversity of opinion. With a readership of nearly 8 million this does not mean adopting a countercultural aesthetic, but perhaps adapting their aesthetic and editorial content to trends of the era. In contrast to this was the text heavy analysis of Rolling Stone, who understood that visual representations were important only as far as they provided something not offered by the nightly newscast. What helped Rolling Stone build its readership during this period was the New Journalism they championed, the diverse range of

${ }^{128}$ Baron Wolman, interview by Rachel Lobo, Toronto, ON, April 28, 2014. 
subjects that their photographs and text offered, and the coopting of an alternative layout and aesthetic. Photographs then did not have to be faithful in tone or colour, dominant in a spread, or neatly organized on a page. In the case of both Life and Rolling Stone, the symbiotic relationship between the types of photographs used, and the layout in which they were arranged asserts the McLuhanian idea that the medium is the message. 


\section{Conclusion:}

In November of 1967 Jann Wenner printed 40,000 copies of the premier issue of Rolling Stone, and 34,000 were returned unsold. ${ }^{129}$ Hoping to tap into his drug friendly audiences, four issues later in a full page ad that shared a spread with the Beatles, Wenner offered a free roach clip with each subscription [FIG. 63]. This crafty marketing scheme read, "Act now before this offer is made illegal."130 This keen ability to tap into the zeitgeist of the times is what has afforded Rolling Stone decades of success where many of its peers have failed. Founded during the Summer of Love in San Francisco, the belly of the counterculture, in its early years the

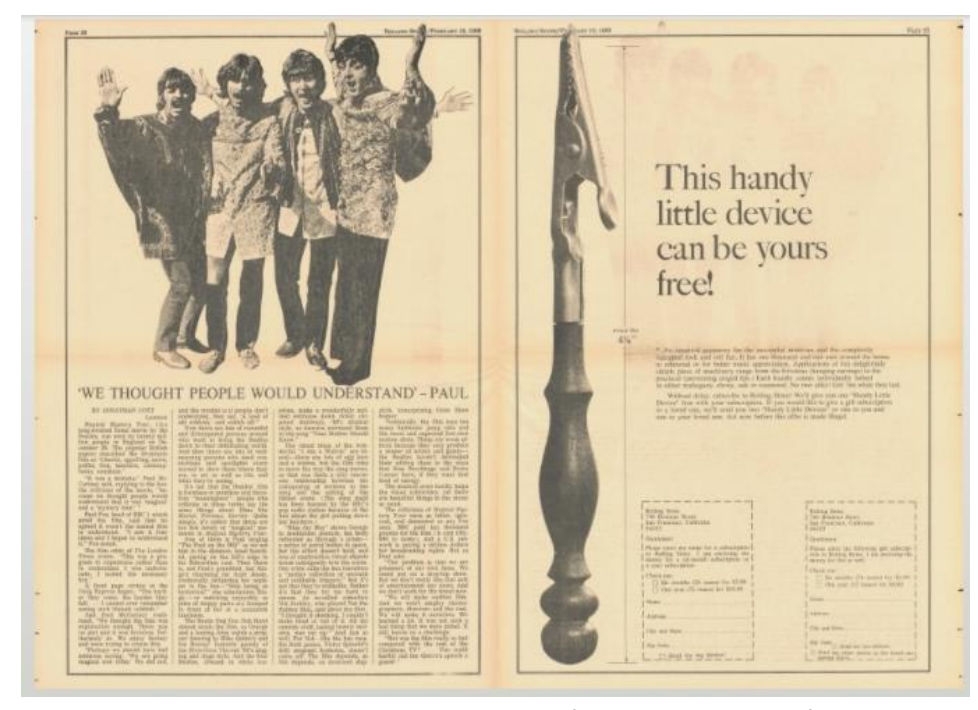

FIGURE 63: Advertisement in Rolling Stone (February 10, 1968), 22-23. writers, photographers and editors at the magazine were completely embedded in the lifestyle of their readership. Their marketing of a roach clip is indicative of this; they knew their audience would not be put off by the promotion of drug use, precisely because they knew their audience. However this is not as pioneering or as courageous a marketing campaign if we look at the content that the underground produced. The underground was founded on the idea of radically changing society for the better, pushing the envelope with incisive editorials and creative content, and in doing so they provided a litmus test for those that came after. Once these floodgates were opened Rolling Stone knew the acceptable scope of discourse, along with it, the kind of design and photographs that were efficient for publication. Though Rolling Stone strove for more professionalism than the underground, they were

129 Peter Carlson, "How Does It Feel? As His Rock Magazine Hits 1,000 Issues, Rolling Stone's Jann Wenner Is Still High on the Concept" in Washington Post, May 4, 2006. 
establishing new visual standards based on the model that underground culture provided in their informal, or lo-fi aesthetic. Operating on a smaller, more local level and with an open-mind, this is what saved Rolling Stone from the fate of the aboveground publications. What allowed them the longevity to excel after the 1960s is the same thing that sustains Rolling Stone today; its ability to adapt.

What became clear in the late 1960s is that the initial ambition of mainstream magazines like Life could not be achieved. Though they sustained a circulation of 8 million in 1969, in the eyes of critics Life's inability to represent the national population only added to their problems. ${ }^{131}$ The myopic vision of American life that Life maintained for 36 years was now looked at by sections of the population with antagonism. More incisively, critic A.D Coleman wrote, "in recent years the appearance of anything in Life-even photographs-actually undermined its credibility with the younger generation because it .... had evolved into a complacent house organ for the middle and upper management of corporate America." ${ }^{132}$ What Coleman's comments articulate is that a new system of visual communication was needed to respond to the demands of a younger generation. The photography and layouts featured in the underground publications did just that; they created an aesthetic that was strikingly different from the mainstream. This aesthetic embraced the sensibilities of the era-immediate or amateur looking photography, the curvature of psychedelic art, the fictive, and the impressionistic reportage of New Journalism.

Well into its middle-age Rolling Stone still delivers to its audience content that taps into the zeitgeist of the time. Though in the 1960s this was often based on its ability to exploit the most commodifiable aspects of the underground, Rolling Stone has outlived these publications because of its adaptability. Unlike the underground which unflinchingly held on to the beliefs and aesthetic of the counterculture, Rolling Stone was not bound to these ideals. For instance by August 1973 their tone had

\footnotetext{
${ }^{131}$ Slater, "Changing Images of the Democratic Party," 7.
} 132 Ibid. 
changed from marketing to an audience who believes "in the magic that can set you free"133, to boldly identifying themselves as "a general interest magazine, covering modern American culture, politics, and arts, with a special interest in music." ${ }^{134}$ This evolution and malleability is clearly demonstrated in the photography that Rolling Stone publishes, perhaps most visibly in their cover photography.

Reflected in all these changes is Rolling Stone's flexibility, always striving to stay ahead of the curve-whether this meant coopting the casual or immediate style of the underground, or publishing increasingly controversial cover photographs. For some this indicated a lack of back bone, while for others this flexibility is imperative in an increasingly competitive media driven world. Either way, this formula has sustained Rolling Stone for six

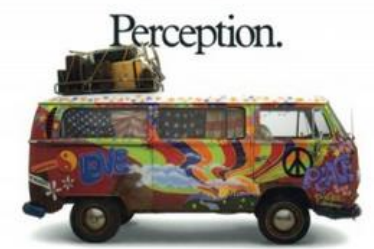
decades. Emblematic of its chameleon characteristics is its 1985 ad campaign titled "Perception/Reality" [FIG. 64], which paired old hippie stereotypes still attached to Rolling Stone, with its new reality. On a white background perceptions were contrasted with reality: perception: pennies, reality: black cards; perception: brownies, reality: Häagen-Dazs; perception: a VW bus, reality: a sports car; perception: a 1970 Rolling Stone cover featuring Jimi Hendrix, reality: 1984 issue featuring Bill Murray. "Perception/Reality" is demonstrative of the kind of clever siphoning capabilities Rolling Stone had when it comes to marketing itself. Though it has undoubtedly gathered moss, it's still rolling.

\footnotetext{
133 Wenner, “Random Notes," 2.

134 Peck, Uncovering the Sixties: The Life and Times of the Underground, 288.
} 


\section{Bibliography}

Histories of Photojournalism- Primary Sources

Chapnick, Howard. Truth Needs No Ally: Inside Photojournalism. Columbia: University of Missouri Press, 1994.

Evans, Harold. Pictures on a Page: Photo-journalism, Graphics and Picture Editing. London: Heinemann, 1978.

Hicks, Wilson. Words and Pictures: An Introduction to Photojournalism. New York: Arno Press, 1973. First published 1952 by Harper and Row Publishers, Inc.

McDougall, Angus. Picture Editing and Layout: A Guide to Better Visual Communication. MO: Columbia Viscom Press, 1990.

Mich, Daniel D. and Edwin Eberman. The Technique of the Picture Story: A Practical Guide to the Production of Visual Articles. New York: McGraw-Hill Book Co., 1945.

Morris, John G. Get the Picture: A Personal History of Photojournalism. Chicago: University of Chicago Press, 2002.

Rothstein, Arthur. Photojournalism: Pictures for Magazines and Newspapers, $2^{\text {nd }}$ American Photographic Book Pub, Co., 1965.

Vitray, Laura, John Mills and Roscoe Ellard. Pictorial Journalism. New York: Arno Press, 1973.

Histories of Photojournalism- Secondary Sources

Cookman, Claude. American Photojournalism: Motivations and Meanings. Evanston: Northwestern University Press, 2009.

Freund, Gisele. "Press Photography." In Photography \& Society. London: Gordon Fraser, 1980.

------. "The Birth of Photojournalism in Germany." In Photography \& Society. London: Gordon Fraser, 1980.

Gidal, Tim N. Modern Photojournalism: Origin and Evolution, 1910-1933. New York: Collier Books, 1972.

Kozol Wendy. Life's America. Philadelphia: Temple University Press, 1994.

Langton, Loup. Photojournalism and Today's News: Creating Visual Reality. Hoboken: Wiley-Blackwell, 2008.

Lebeck, Robert and Bobo Von Dewitz. Kiosk: Eine Geschichte der Fotoreportage 1839-1973/ A History of Photojournalism. Göttingen: Steidl, 2001.

Lewis, Greg. Photojournalism: Content and Technique. New York: McGraw-Hill Higher Education, 1994.

Panzer, Mary. Things as They Are: Photojournalism in Context since 1955. London: World Press Photo, 2005.

Histories of Photography 
Freund, Gisele. Photography \& Society. London: Gordon Fraser, 1980.

Frizot, Michel. A New History of Photography. New York: Konemann, 1997.

Rosenblum, Naomi. The World History of Photography. New York: Abbeville Press, 2007.

Werner Marien, Mary. Photography: A Cultural History. London: Pearson Publishing, 2010.

Texts on Photography

BBC Television. "The Genius of Photography: Ed Rushca." Accessed June 15, 2014. http://www.bbc.co.uk/photography/genius/gallery/ruscha.shtml

Coleman, A.D. "Life May Have Died, But Photography Lives On." In Light Readings: A Photography Critic's Writings 1968-1978. New York: Oxford University Press, 1979.

Craske, Oliver. Rock Faces - The World's Top Rock ' $n$ ' Roll Photographers and Their Greatest Images Sussex: Rotovision, 2004.

Grunenberg, Christoph and Jonathan Harris. Summer of Love: Psychedelic Art, Social Crisis and Counterculture in the 1960s. Liverpool: Liverpool University Press, 2005.

Harper's Bazaar Staff. “Linda McCartney Photographs.” Harper's Bazaar, March 22, 2011.

Malpas, James. Realism. Cambridge: Cambridge University Press, 1997.

Marshall, Richard D. Ed Ruscha. Oxford: Phaidon Press, 2005.

Miranda, Carolina. "In Ed Ruscha's Work, A City Sits For Its Portrait." in National Public Radio, September 22, 2013.

Prendeville, Brendan. Realism in 20 ${ }^{\text {th }}$ Century Painting. London: Thames \& Hudson Ltd., 2000.

Rosenberg, Karen. “Everyone's Lives, in Pictures."in New York Times, April 21, 2012.

Warhol, Andy. Andy Warhol's Exposures. New York: Putnam Publishing Group, 1980.

Wolf, Sylvia. Ed Ruscha and Photography. New York: Steidl Publishers, 2006.

\section{Histories of Journalism}

Compaine, Benjamin M. The Business of Consumer Magazines. White Plains: Knowledge Industry Publications Inc., 1982.

Goudreau, Jenna. "Vogue's Anna Wintour: Intimidating, No. Powerful, Yes.", Forbes Magazine Online, Accessed May 1, 2014.

Muhlmann, Géraldine. A Political History of Journalism. Cambridge: Polity Press, 2008.

Schudson, Michael. Discovering the News: A Social History of American Newspapers. New York: Basic Books Inc., 1967. 
Sumner, David E. The Magazine Century: American Magazines Since 1990. New York: Peter Lang Publishing, 2010.

Tebbel, John and Mary Ellen Zuckerman. The Magazine in America: 1741-1990. New York: Oxford University Press, 1991.

Zara, Christopher. "In Memoriam: Magazines We Lost In 2012." International Business Times, December 222012.

Histories of the Underground Press

Armstrong, David. A Trumpet to Arms: Alternative Media in America. Los Angeles: Houghton Mifflin Company, 1981.

Glessing, Robert J. The Underground Press in America. Bloomington: Indiana University Press, 1970.

Heller, Steven. “Underground Mainstream." The Design Observer Group, April 10, 2008.

Hoffman, Abbie. "1971 Underground Press Syndicate Roster." The Rag, 1971.

McMillian, John. Smoking Typewriters: The Sixties Underground Press and the Rise of Alternative Media in America. Oxford: Oxford University Press, 2011.

Peck, Abe. Uncovering the Sixties: The Life and Times of the Underground. New York: Pantheon, 1985.

Richardson, Peter. A Bomb in Every Issue: How the Short, Unruly Life of Ramparts Magazine Changed America. New York: New Press, 2009.

Spencer, Amy. DIY: the Rise of Lo-fi Culture. New York: Marion Boyars, 2008.

Stewart, Sean. On the Ground: An Illustrated Anecdotal History of the Sixties Underground Press in the U.S. Oakland: PM Press, 2011.

\section{Histories of America}

Chafe, William H. The Unfinished Journey: America Since World War II. New York: Oxford University Press, 1986.

Chantrill, Christopher. "Total Spending for the US- Fiscal Year 1962," US Government Spending. http://www.usgovernmentspending.com/piechart_1962_US_total (Accessed August 31, 2014).

Chomsky, Noam. "The Legacy of the Vietnam War." Indochina Newsletter, Issue 18 (October, 1982).

Dickstein, Morris. Gates if Eden: American Culture in the Sixties. New York: Basic Books, Inc., Publishers, 1977.

Falk, Gerhard. Youth Culture and the Generation Gap. New York, Algora Publishing, 2005.

Howe, Neil and William Strauss. "The New Generation Gap." The Atlantic, December 1992.

Johnson, Paul. A History of the American People. London: Weidenfeld \& Nicolson, 1997

Zinn, Howard. A People's History of the United States. New York: Harper Perennial, 1999.

------. Postwar America: 1945-1971. Indianapolis: Bobbs-Merrill, 1973. 


\section{Academic Sources}

Batchen, Batchen. “Snapshots.” Photographies, Vol. 1, Iss. 2, 2008.

Bennett, W. Lance. "Towards a Theory of Press-State Relations in the United States." Journal of Communication 40, no. 2, 1990: 103-125.

Cohen, Madelaine. "Gather No Moss: Vietnam and the Political Evolution of Rolling Stone Magazine." MA dissertation, Stanford University, 2011.

Cooper, Hilla. "Reading Magazines: Stefan Lorant and Picture Post, 1939-1941." MA dissertation, Ryerson University, 2012.

Gennari, John. "Bridging Two Americas: Life Looks at the 1960s." In Looking at Life Magazine Washington: Smithsonian Institution Press, 2001.

Gervais, Thierry, Christian Delage et al. "Beyond the Photograph, Redefining the Press." In Études photographiques 7 (June 2000): 4-5.

Gleason, Ralph J. "Like a Rolling Stone." American Scholar, Autumn 1967.

Hill, Jason. "On the Efficacy of Artifice: PM, Radiophoto, and the Journalistic Discourse of Photographic Objectivity." In Études photographiques 26 (November 2012): 71-85.

Slater, Rick. "Changing Images of the Democratic Party: An Analysis of the Aesthetic and Philosophical Underpinnings of Life's Photo-Essay 'Happy days in Miami'." MA dissertation, Ryerson University, 2009.

Spencer, Otha Cleo. "Twenty years of Life : a Study of Time, Inc.'s Picture Magazine and its Contributions to Photojournalism." PhD dissertation, University of Missouri: 1958.

Thorton, Gene. "The End of a Great Era." New York Times, December 24, 1972.

Vials, Christopher. Realism for the Masses: Aesthetics, Popular Front Pluralism, and U.S. Culture, 19351947. Oxford: University of Mississippi Press, 2013.

\section{Typography and Graphic Design}

Ambrose, Paul. The Visual Dictionary of Typography. Worthing: Ava Publishing, 2010.

Kaplan, Geoff. Power to the People: The Graphic Design of the Radical Press and the Rise of the Counter-Culture, 1964-1974. New York: University of Chicago Press, 2013.

Lupton, Ellen. Mixing Messages: Graphic Design in Contemporary Culture. New York: Cooper- Hewitt, 1996.

\section{Offset Printing and Linotype}

Arbel Oscar R., and Windsor A. Straw. Mechanism of the Linotype and Intertype. Brookings: Lebawarts Press, 1950.

Chambers, Harry T. The Management of Small-Offset Print Departments. London: Business Books Limited, 1969.

Cogoli, John E. Photo-Offset Fundamentals. Bloomington: McKnight Publishing Company, 1980. 
Moen, Daryl R. Newspaper Layout and Design. Ames: lowa State University Press, 1984.

\section{Rolling Stone Articles}

Landau, Jon. “Rock 1970.” Rolling Stone, December 10, 1970.

------. "The Newport Rock Festival." Rolling Stone, August 24, 1968.

Marcus, Griel. "The Woodstock Festival." Rolling Stone, September 20, 1969.

Rossman, Michael. "Revolution 1969." Rolling Stone. April 5, 1969.

Thompson, Hunter S. "The Battle of Aspen." Rolling Stone. October 1, 1977.

------. "Traditional Politics with a Vengeance." Rolling Stone, July 6, 1972.

Wenner, Jann. "A Letter from the Editor." Rolling Stone. November 9, 1967.

------. “Contributions." Rolling Stone. November 23, 1967.

------. "Revolutionary, Wild, Unpredictable-and that was just the Writers." The Independent (London). May 10, 2007.

\section{Studies of Rolling Stone}

Carlson, Peter. "How Does It Feel? As His Rock Magazine Hits 1,000 Issues, Rolling Stone's Jann Wenner is Still High on Concept." Washington Post, May 4, 2006.

Dahl, Shawn. Rolling Stone, the Seventies. Boston: Little Brown, 1998.

Draper, Robert. Rolling Stone Magazine: An Uncensored History. New York: Harper Perennial, 1991.

Hoffman, Nicholas. "Rolling Stone Gathers Youth." Washington Post, April 23, 1969.

Nelson, Alix. "The Rolling Stone Reader." The New York Times Book Review, April 14, 1974.

Rolling Stone Magazine. Rolling Stone 1,000 Covers: A History of the Most Influential Magazine in Pop Culture. New York: Harry N. Abrams, 2006.

Steinberg, Brian. “Questions for... Jann Wenner." Wall Street Journal. April 12, 2006.

"Wenner Media, Inc. History." Funding Universe. Accessed April 25, 2014, http://www.fundinguniverse.com/company-histories/wenner-media-inc-history/

Other

Cashmore, Ellis. Celebrity Culture. London: Taylor \& Francis, 2006.

Dylan, Bob. "The Times They a-Changin'." (Song Lyrics). Accessed April 30, 2014.

http://www.metrolyrics.com/the-times-they-are-achangin-lyrics-bob-dylan.html

“Little Brown Miscelleanea: I am the boss." TIME Lightbox Tumblr. Accessed May 1, 2014. 
Rectanus, Mark W. Culture Incorporated: Museums, Artists, and Corporate Sponsorships. Minnesota: University Of Minnesota Press, 2002.

Silverstein, Shel. "The Cover of the Rolling Stone" (Song Lyrics). Accessed May 2, 2014. http://www.azlyrics.com/lyrics/drhook/thecoveroftherollingstone.html 
Appendix: Baron Wolman Interview:

1. It is my understanding that in its early years photographers at Rolling Stone worked on a volunteer or informal basis. In your experience, were particular photographers sought out, or did they come to the editors looking for work?

As you know, I was the only staff photographer. Beyond me, a little of both; there were photographers shooting music with whom we were acquainted and knew they would do a good job. Then there were other good local photographers who, once we started publishing and they saw how cool the magazine was, came to us offering their services. At the time we were not challenged with the current situation of "everybody is a photographer." We could choose among those few who were talented working professional photographers.

2. How were stories assigned to photographers at Rolling Stone? Once an assignment was completed how much say did a photographer have in the photographs chosen for print, or how they were presented?

Sometimes we worked with a writer, especially on cover stories. We knew the subject and we knew how to take good pictures. Very little direction was given. I, at least, had as much input in the print selection as I wanted; however, I fully trusted the art director and usually preferred to be surprised by his choices which almost always ended up being good ones. Back in the day, the editors trusted us photographers to bring back plenty of good photos from any assignment we were given, be it a concert, a portrait session or whatever. And we did!

3. Was there a certain style of photograph that you noticed was used more regularly than others? How was a photograph deemed efficient at Rolling Stone?

The style was "real." What did the concert really look like, what was it like to have been there, to have seen a particular musician perform. For portraits, the same: who was the musician, what did he or she really look like. Deification came later, one of the reasons I left. Once the musicians began seeing themselves on TV and in music videos they were less interested in how they really looked rather how they wanted to be perceived; they started managing their look. Borrrrring. Remember that when we started publishing virtually no publication was showing the real side of rock and roll - the only way readers could see what their heroes and heroines looked like was on the pages of Rolling Stone. I always tried to dignify my subjects with my photos, to thank them for their music that made me so happy...

4. How do you think the underground press or mainstream press influenced Rolling Stone? Where do you see it fitting in to the history of the illustrated press?

The ONLY way the underground press influenced us was to show that it was possible and relatively easy to start a publication in the late sixties. From Day One, Jann emphasized we were not "underground," we were a bona fide professional publication which just happened to be printed on newsprint. Our goal, his goal, was to be successful editorially and financially. 


\section{What role did photographs play in the magazine?}

The photos played a HUGE roll, from the covers to illustrating the editorial well. The art director respected the photos, ran them big when he thought they looked better large. As I said, before MTV, before the Internet, people got their visual information about music and musicians (and politics) from the harmony of pictures and words - Rolling Stone was virtually their only source.

\section{How do you think the magazine was influenced by the politics of the time?}

Big time - I assume you've gone back through the early issues. As is the case today, the subject of politics, America's dysfunctional political system, was often the subject of long, thoughtful stories.

7. What was your experience photographing the Woodstock Festival? How do you feel about the final product of that story, "The Woodstock Festival"?

I was on a three-day high photographing Woodstock. Because I had photographed most of the performers by then, I concentrated on the "Woodstock Experience," what it meant to have been there, to have attended the event. A collection of these photos is about to be published in a book, the first book that reflects upon what it meant to be there rather than what the music was like. I interviewed Carlos Santana - his words will be the foreword. Then Michael Land and I and the editor, Dagon James, sat down for long conversations about the concert - how it came to be, what it was like during the three days, and how it ended. Long portions of those conversations appear in the book. I expect it to be a "keeper," and to answer many of the lingering questions about the original festival, both in words and photos.

\section{Why do you think that when we talk about the photographs used at Rolling Stone, only the cover photography is mentioned?}

That's news to me? Who is the "we" who is doing the talking...??? Taken as a whole, the collection of covers does reflect changes in America, from the nature of the photos themselves, to the change in Rolling Stone from black \& white only to color, to the style of the photographs which reflected changing style of dress and music, and finally to the unfortunate current requirements for magazine success only "in your face" covers will attract buyers. For the most part I am bored by the Rolling Stone covers over the last couple of decades. They are "manufactured." The interior pages are not much better; mostly insignificant and boring, only occasionally evocative and/or provocative. Very seldom am I "stopped" by a particular image in the magazine these days. This can't be blamed entirely upon the magazine; the world is awash in images - photographs are no longer held in much esteem. When "good enough" is good enough, something significant has been lost... 